


\section{CAREC CORRIDOR PERFORMANCE MEASUREMENT AND MONITORING ANNUAL REPORT 2019}


(c) 2020 Asian Development Bank 6 ADB Avenue, Mandaluyong City, 1550 Metro Manila, Philippines

Tel +6328632 4444; Fax +63286362444

www.adb.org

Some rights reserved. Published in 2019.

ISBN 978-92-9262-294-7 (print), 978-92-9262-295-4 (electronic), 978-92-9262-296-1(ebook)

Publication Stock No. TCS200205-2

DOI: http://dx.doi.org/10.22617/TCS200205-2

The views expressed in this publication are those of the authors and do not necessarily reflect the views and policies of the Asian Development Bank (ADB) or its Board of Governors or the governments they represent.

ADB does not guarantee the accuracy of the data included in this publication and accepts no responsibility for any consequence of their use. The mention of specific companies or products of manufacturers does not imply that they are endorsed or recommended by ADB in preference to others of a similar nature that are not mentioned.

By making any designation of or reference to a particular territory or geographic area, or by using the term "country" in this document, $A D B$ does not intend to make any judgments as to the legal or other status of any territory or area.

This work is available under the Creative Commons Attribution 3.0 IGO license (CC BY 3.0 IGO)

https://creativecommons.org/licenses/by/3.0/igo/. By using the content of this publication, you agree to be bound by the terms of this license. For attribution, translations, adaptations, and permissions, please read the provisions and terms of use at https://www.adb.org/terms-use\#openaccess.

This CC license does not apply to non-ADB copyright materials in this publication. If the material is attributed to another source, please contact the copyright owner or publisher of that source for permission to reproduce it. ADB cannot be held liable for any claims that arise as a result of your use of the material.

Please contact pubsmarketing@adb.org if you have questions or comments with respect to content, or if you wish to obtain copyright permission for your intended uses that do not fall within these terms, or for permission to use the ADB logo.

Corrigenda to ADB publications may be found at http://www.adb.org/publications/corrigenda.

Notes:

In this publication, "\$" refers to United States dollars.

ADB recognizes "China" as the People's Republic of China.

Cover design by Principe Nicdao. 


\section{Contents}

Tables, Figures, and Boxes

Acknowledgments

Abbreviations

Executive Summary

vii

viii

1 Introduction 1

Background 1

22019 Key Results 5

Trade Facilitation Indicator Results for 2019: Road Transport 5

Trade Facilitation Indicator Results for 2019: Rail Transport $\quad 7$

Trade Facilitation Indicator Trends 2010-2019 9

32019 Corridor Performance Measurement and Monitoring Data 13

Data Profile 13

$\begin{array}{ll}\text { Cargo Movement } & 14\end{array}$

4 Road Transport in $2019 \quad 18$

Trade Facilitation Indicator 1: Average Border-Crossing Time 18

Trade Facilitation Indicator 2: Average Border-Crossing Cost 18

Trade Facilitation Indicator 3: Total Transport Cost $\quad 20$

Trade Facilitation Indicator 4: Speed to Travel on CAREC Corridors 21

$\begin{array}{ll}\text { Corridor Performance } & 21\end{array}$

5 Rail Transport in $2019 \quad 28$

Trade Facilitation Indicator 1: Average Border-Crossing Time 28

Trade Facilitation Indicator 2: Average Border-Crossing Cost 29

Trade Facilitation Indicator 3: Total Transport Cost 29

Trade Facilitation Indicator 4: Speed to Travel on CAREC Corridors 30

Corridor Performance $\quad 30$

6 Country Updates $\quad 34$

Afghanistan $\quad 34$

Azerbaijan $\quad 36$

People's Republic of China 38

$\begin{array}{ll}\text { Georgia } & 40\end{array}$

$\begin{array}{ll}\text { Kazakhstan } & 42\end{array}$

Kyrgyz Republic $\quad 46$

$\begin{array}{ll}\text { Mongolia } & 48\end{array}$

$\begin{array}{ll}\text { Pakistan } & 50\end{array}$

Tajikistan $\quad 53$

Turkmenistan $\quad 55$

Uzbekistan 
7 Corridor Performance Measurement and Monitoring and Time Release Study Tools 60

$\begin{array}{ll}\text { Background } & 60\end{array}$

Time Release Study Methodology 61

Time Release Study Findings: Sarpi Border-Crossing Point and Poti 61

Key Lessons Learned from the Time Release Study 63

Comparison of Corridor Performance Measurement and Monitoring and Time Release Study 63

Comparison of Methodologies 64

Findings: Similarities and Differences 64

Complementarity between Corridor Performance Measurement and Monitoring 65 and Time Release Study Tools

8 Conclusion $\quad 68$

Appendixes

1 Corridor Performance Measurement and Monitoring Methodology 69

22019 Partner Associations 72

3 Trade Facilitation Indicators

4 Border-Crossing Activities $\quad 79$

5 Central Asia Regional Economic Cooperation Border-Crossing Points 82

6 Trade Facilitation Indicators: Summary Statistics 84

7 Activities at Road Border-Crossing Points 86

8 Activities at Rail Border-Crossing Points 94 


\section{Tables, Figures, and Boxes}

Tables

3 CAREC Corridor Alignment and Key Border-Crossing Points $\quad 15$

4.1 Average Time Taken to Clear a Border-Crossing Point 18

4.2 Average Cost Incurred at Border-Crossing Clearance 18

4.3 Average Cost at Road Border-Crossing Points by Activity 19

4.4 Estimated Unofficial Fees Paid per Activity for Road Transport in 2019

4.5 Average Cost Incurred to Travel a Corridor Section 20

4.6 Average Speed to Travel on CAREC Corridors 21

4.7 Transports Internationaux Routiers-Enabled People's Republic of China 23

Border-Crossing Points

4.8 Key Indicators of Shipments from Poti, Georgia to Central Asia 24

4.9 Comparisons of Trade Facilitation Indicators between Corridors 3a and 3b in 2019

4.10 Comparison of Average Border-Crossing Times in Subcorridors 3a and 3b 25

4.11 Comparisons of Road and Road-Rail Shipments along Subcorridor 4b 26

5.1 Average Time Taken to Clear a Border-Crossing Point 28

5.2 Average Cost Incurred at Border-Crossing Clearance 29

5.3 Average Cost Incurred to Travel a Corridor Section 29

5.4 Average Speed to Travel on CAREC Corridors 30

5.5 Transit Rail Container Traffic Direction, 2014-2018 32

6.1 Trade Facilitation Indicators for Afghanistan 34

6.2 Border-Crossing Performance in Afghanistan $\quad 35$

6.3 Trade Facilitation Indicators for Azerbaijan 36

6.4 Border-Crossing Performance in Azerbaijan 37

6.5 Trade Facilitation Indicators for the People's Republic of China 38

6.6 Border-Crossing Performance in the People's Republic of China 39

6.7 Trade Facilitation Indicators for Georgia 40

6.8 Border-Crossing Performance in Georgia 41

6.9 Trade Facilitation Indicators for Kazakhstan 43

6.10 Border-Crossing Performance in Kazakhstan 43

6.11 Trade Facilitation Indicators for the Kyrgyz Republic $\quad 47$

6.12 Border-Crossing Performance in the Kyrgyz Republic 47

6.13 Trade Facilitation Indicators for Mongolia 48

6.14 Border-Crossing Performance in Mongolia 49

6.15 Trade Facilitation Indicators for Pakistan $\quad 51$

6.16 Border-Crossing Performance in Pakistan 51

6.17 Trade Facilitation Indicators for Tajikistan 53

6.18 Border-Crossing Performance in Tajikistan 54

6.19 Trade Facilitation Indicators for Turkmenistan 56

6.20 Border-Crossing Performance in Turkmenistan 56

6.21 Trade Facilitation Indicators for Uzbekistan 57

6.22 Border-Crossing Performance in Uzbekistan 58

7.1 Average Clearance Times for Poti, 2016

7.2 Distinguishing Factors between the Corridor Performance Measurement and Monitoring 64 and Time Release Study

$8 \quad$ Road and Rail Transport Trade Facilitation Indicators, $2019 \quad 68$

A2 2019 Corridor Performance Measurement and Monitoring Partner Associations $\quad 72$

A3 Measuring the Trade Facilitation Indicators 74

A5 CAREC Corridor Border-Crossing Points 82 
A6 Trade Facilitation Indicators-Summary Statistics 84

A7.1 Time and Cost Spent at Road Border-Crossing Points, Outbound 86

A7.2 Time and Cost Spent at Road Border-Crossing Points, Inbound 90

A8 Time and Cost Spent at Rail Border-Crossing Points, Outbound and Inbound 94

Figures

A Road Transport Trade Facilitation Indicators $\quad$ ix

B Rail Transport Trade Facilitation Indicators x

1.1 Six CAREC Transport Corridors 2

1.2 Corridor Performance Measurement and Monitoring Methodology 3

2.1 Time Taken to Clear a Border-Crossing Point, Road Transport 5

2.2 Cost Incurred at Border-Crossing Clearance, Road Transport 6

2.3 Cost Incurred to Travel a Corridor Section, Road Transport 6

2.4 Speed to Travel on CAREC Corridors, Road Transport 7

2.5 Time Taken to Clear a Border-Crossing Point, Rail Transport 7

2.6 Cost Incurred at Border-Crossing Clearance, Rail Transport 8

2.7 Cost Incurred to Travel a Corridor Section, Rail Transport 8

2.8 Speed to Travel on CAREC Corridors, Rail Transport 9

2.9 Trend of Trade Facilitation Indicators for Combined Road and Rail Transport, 9 2010-2019

2.10 Average Speed along CAREC Road Transport Corridors, 2014 11

2.11 Average Speed along CAREC Road Transport Corridors, 2019 12

3.1 Data Profile of Corridor Performance Measurement and Monitoring Samples in $2019 \quad 13$

3.2 Number of Shipment, by Type of Commodity 14

4.1 Comparisons of Corridor Performance: Average Border-Crossing Duration 22 versus Cost, 2019

4.2 Comparing Torkham Border-Crossing Time before and after 24/7 Implementation 27

6.1 Freight Carried by Different Transport Modes in Mongolia, 2015-2019 49

6.2 Estimated Waiting Time in Line at Peshawar and Torkham Border-Crossing Points 51 before and after 24/7 Implementation

7.1 Time Release Study Average Time to Complete Documentary Compliance at Sarpi 62

7.2 Time Release Study Average Time to Complete Physical Examinations at Sarpi 62

7.3 Potential Steps and Data Flow for Corridor Performance Measurement and Monitoring 66 and Time Release Study Complementarity

7.4 Sample Process Map on the Standard Declaration in Georgia 66

A1 Corridor Performance Measurement and Monitoring Flowchart 70

A3 Measuring the Trade Facilitation Indicators 74

Boxes

4.1 Persistent Barriers to Faster Cheaper Road Transport Trade in CAREC Corridors 23

5.1 Persistent Barriers to Faster Cheaper Rail Transport in CAREC Corridors 31 


\section{Acknowledgments}

This technical report was prepared by the Asian Development Bank (ADB) Central Asia Regional Economic Cooperation (CAREC) Corridor Performance Measurement and Monitoring (CPMM) team led by Rose McKenzie, senior regional cooperation and integration specialist; with Max Ee Khong Kie, ADB international consultant; Andy Sze, ADB international consultant; Julius Santos, ADB national consultant; and Ma. Bernadette Y. De Castro, project analyst, as team members. Director General James Lynch, Deputy Director General M. Teresa Kho, and Director Xiaoqin Fan provided overall guidance. The CAREC Institute CPMM team provided valuable commentary on the report, including Iskandar Abdullaev, deputy director 2, CAREC Institute; Hans Holzhacker, chief economist; Tamar Berdzenishvili, senior knowledge management specialist; Ghulam Samad, senior research specialist; and Chen Long, knowledge management officer. ADB is grateful to Samson Uridia, head of revenue service, International Relations Department, Georgia Revenue Service; and Mikheil Peikrishvili, adviser, International Relations Department, Georgia Revenue Service, who provided data and inputs to Chapter 7 of the report.

Yuebin Zhang, principal regional cooperation specialist; Saad Paracha, senior regional cooperation specialist; Oleg Samukhin, senior transport specialist; and Kijin Kim, economist, peer-reviewed the draft report.

CAREC CPMM in-country partners are established national carrier and forwarder associations in CAREC member countries and are essential to the success of the CPMM mechanism. For the 2019 CPMM cycle, ADB gratefully recognizes the following national associations: the Association of Afghanistan Freight Forwarding Companies; the Chongqing International Freight Forwarders Association, Inner Mongolia Autonomous Region Logistics Association, and Xinjiang Uygur Autonomous Region Logistics Association (People's Republic of China); the Georgia International Road Carriers Association; the Association of National Freight Forwarders of the Republic of Kazakhstan; the Freight Operators Association (Kyrgyz Republic); the Federation of Mongolian Freight Forwarders, Mongolia Chamber of Commerce and Industry, and the National Road Transport Association of Mongolia; the Pakistan International Freight Forwarders Association; the Association of Road Transport Operators of Republic of Tajikistan and the Association of International Automobile Transport of Tajikistan; and the Association for Development of Business Logistics and the Association of International Road Carriers of Uzbekistan.

The team is grateful to ADB staff at headquarters and in the CAREC country resident missions for their support and inputs. For production of the report, we note the strong contributions of Edith Joan Nacpil, Sophia Castillo-Plaza, Abraham Villanueva, Principe Nicdao, Monina Gamboa, Svetlana Chirkova, Elena Tsoi, and Rustam Sataev.

The CPMM 2019 Annual Report is published in memory of Yuri Nevenchanny, who set the bar in translation of the first seven CPMM annual reports and who will be sorely missed by the CPMM team.

CPMM activities and publications are funded through technical assistance supported by the ADBadministered Regional Cooperation and Integration Fund. 


\section{Abbreviations}

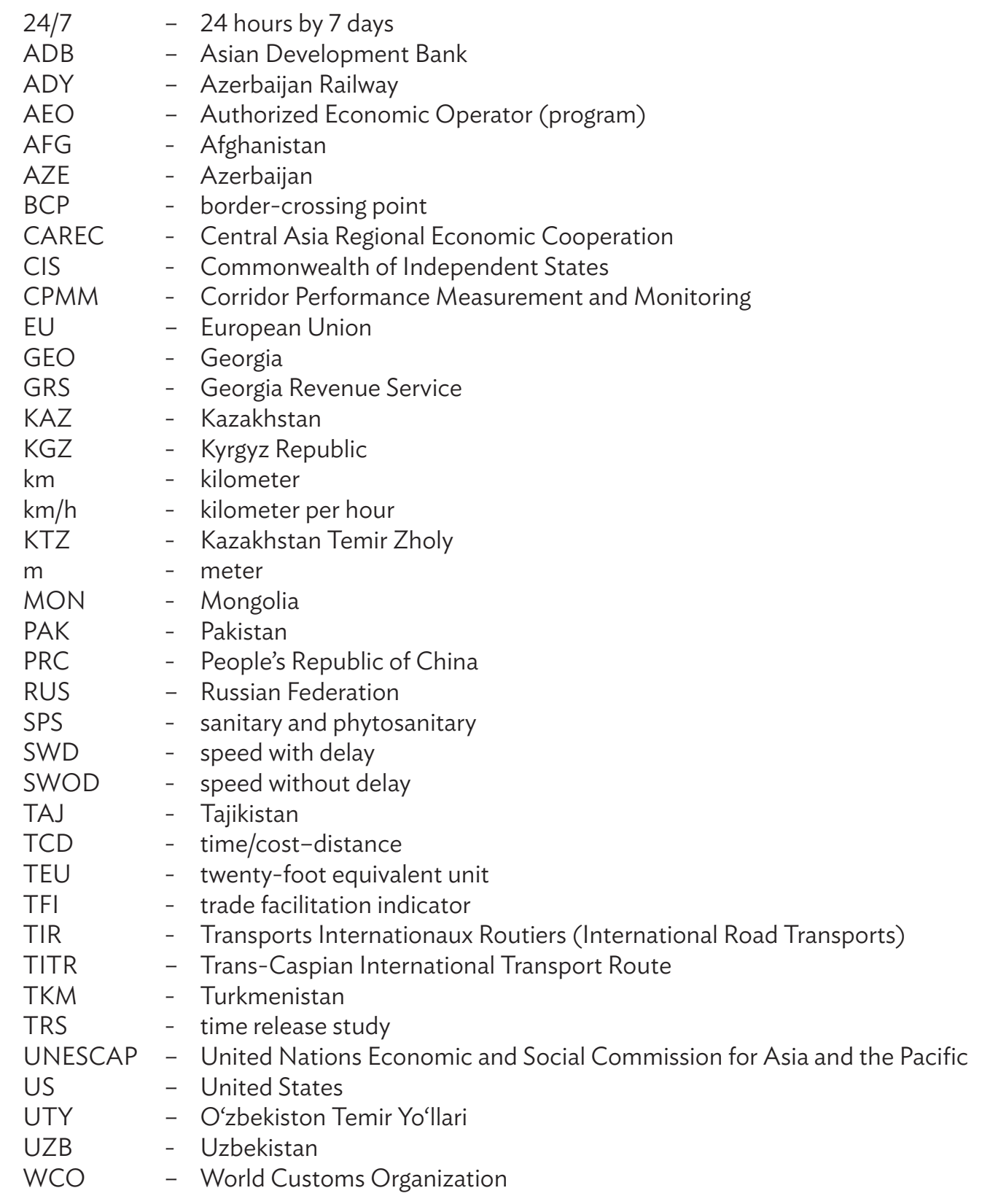




\section{Executive Summary}

The Corridor Performance Measurement and Monitoring (CPMM) mechanism is an empirical tool designed by the Central Asia Regional Economic Cooperation (CAREC) Program to assess and track the time and cost of moving goods across borders and along the six CAREC corridors, spanning the 11 participating countries-Afghanistan, Azerbaijan, the People's Republic of China (PRC), Georgia, Kazakhstan, the Kyrgyz Republic, Mongolia, Pakistan, Tajikistan, Turkmenistan, and Uzbekistan.

The CPMM evaluates a set of trade facilitation indicators (TFIs) to illustrate the overall annual performance and efficiency of the CAREC corridors. Measured over time and across corridors, the indicators provide a comparative picture that allows the assessment and validation of impacts of transport and trade initiatives in the region. The TFIs include (i) time taken to clear a border-crossing point (BCP), (ii) cost incurred at a $B C P$, (iii) cost incurred to travel a corridor sector, and (iv) speed to travel along CAREC corridors.

Data analysis, based on the TFIs, contributes to reform and modernization initiatives that foster seamless transport and trade facilitation within the CAREC region. Central to the CPMM's success and sustainability are (i) private sector participation, (ii) fact-based and data-driven conclusions, and (iii) adaptability to landlocked countries.

CPMM data for 2019 reported comparatively diverging results for road and rail transport. While average border-crossing time (TFI1) remained unchanged for road, TFI1 for rail transport improved by $11.3 \%$. Average border-crossing costs (TFI2) deteriorated and increased for both road (4.1\%) and rail (1.2\%). On the other hand, good progress in total average transport cost (TFI3) showed a decline of $5.5 \%$ for road transport and $15.5 \%$ for rail. Overall average road speed (TFI4) decreased, while overall average rail speed increased. For road transport, average speed without delay (SWOD) fell by $3.2 \%$, and speed with delay (SWD) fell by 5.9\%. However, for rail transport, robust results showed an increase of $19 \%$ for average SWOD, and of $26.9 \%$ for average SWD.

\section{Road Transport}

One TFl improved, one remained unchanged, and two did not fare as well (Figure A). Compared to 2018, average border-crossing time was relatively unchanged from 12.0 hours to 12.2 hours (up $1.4 \%$ ), while

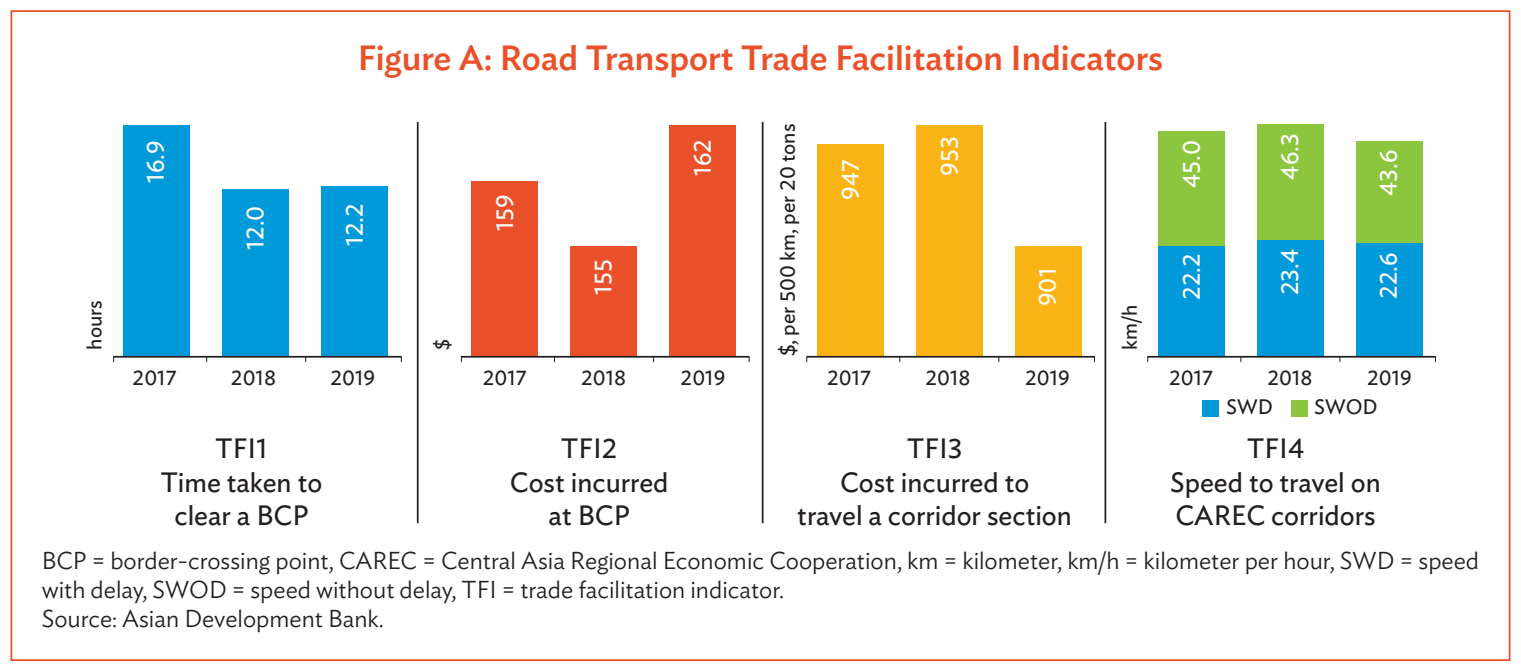


average cost increased from $\$ 155$ to $\$ 162$ (up 4.1\%). Unofficial payments were most prevalent for activities including customs control, commercial inspection, and loading and unloading at high-traffic BCPs.

Total average road transport cost decreased by 5.5\%, from $\$ 953$ to $\$ 901$. SWOD decreased by $5.9 \%$, from 46.3 kilometers per hour $(\mathrm{km} / \mathrm{h})$ to $43.6 \mathrm{~km} / \mathrm{h}$; and SWD also deteriorated by $3.2 \%$, from $23.4 \mathrm{~km} / \mathrm{h}$ to $22.6 \mathrm{~km} / \mathrm{h}$.

\section{Rail Transport}

Rail transport indicators for 2019 (Figure B) showed that average border-crossing times improved by $11.3 \%$, from 23.2 hours to 20.6 hours; while average cost remained relatively unchanged with a minor $1.2 \%$ increase, from $\$ 196$ to $\$ 198$. Total average freight rates for rail fell $15.5 \%$, from $\$ 970$ to $\$ 820$. SWOD and SWD both improved in 2019: SWOD increased 26.9\%, from $35.4 \mathrm{~km} / \mathrm{h}$ to $45 \mathrm{~km} / \mathrm{h}$; and SWD rose $19.0 \%$ from $15.9 \mathrm{~km} / \mathrm{h}$ to $19.0 \mathrm{~km} / \mathrm{h}$.

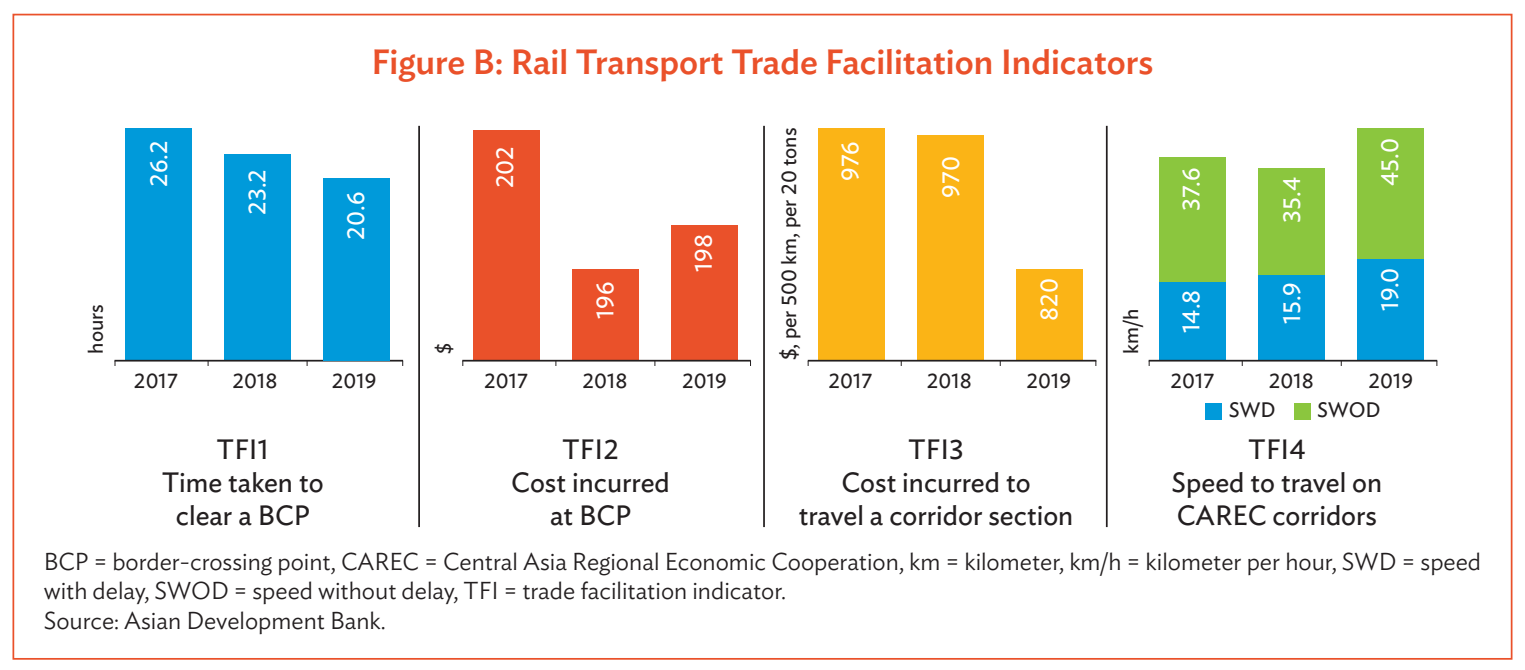

\section{Country Updates}

The 2019 CPMM annual report continues analysis of the four CPMM TFls at the national level for all 11 CAREC countries, segregated by road and rail transport, and further decomposed into outbound and inbound direction for border-crossing time and costs. These data are supplemented by average bordercrossing time and cost estimates for BCPs along relevant CAREC corridors. Country-level developments and challenges are also identified to assist national policy makers in determining the necessary focus of national strategies to address both national and regional transport, trade, and trade facilitation problems. Further details are provided in subsequent chapters.

Afghanistan. Some of the most time-consuming BCPs monitored by the CPMM are in Afghanistan, including Torkham, Spin Buldak, and Shirkhan Bandar, due to long border-crossing clearance. In 2019, however, Torkham BCP began 24 hours by 7 days (24/7) operations which rapidly decreased bordercrossing times. 2019 also saw the first export shipment by rail from Afghanistan to the PRC, transiting Uzbekistan and Kazakhstan.

Kazakhstan. With increased time and cost for average border crossing in 2019, CPMM data for Kazakhstan showed mixed results in 2019. Long delays were indicated especially at Karasu BCP largely due to anti-smuggling measures in March-April 2019. Rail transport showed a commendable increase in 
SWOD, although not at Dostyk rail BCP, which stood out as the most time-consuming BCP due to a lack of available wagons. The PRC increased the length of its trains crossing into Kazakhstan to a maximum of 70 wagons, causing infrastructure problems, for example, at Altynkol BCP in Kazakhstan which suffered from insufficient shunting locomotives and track.

Kyrgyz Republic. CPMM data showed better year-on-year overall performance, with the exception of average border-crossing times. Anti-smuggling initiatives at BCPs with Kazakhstan directed at Kyrgyz vehicles carrying shipments from the PRC required detailed physical inspections at Karasu BCP, adding very significant time to border crossings. Additional physical inspections of this type also led to an increase in demands for unofficial payments.

Mongolia. For road travel in 2019, all indicators deteriorated with the only exception being a drop in the cost to travel a CAREC corridor section. Indicators for rail transport performed only slightly better with cost and speed to travel CAREC corridors showing improvement. Rapid growth of close to $17 \%$ in both freight tonnage and freight turnover was registered during 2015-2019 for transit shipments. To support long-term rail traffic growth, Mongolia continues to prioritize extension of rail connections from Tavan Tolgoi to Zunnbayan and Gashuun Sukhait, which will facilitate domestic transport and export of Tavan Tolgoi's rich deposits of coal and other mineral resources to the PRC and the Russian Federation.

Pakistan. CPMM data reported modest improvement in total average transport cost, although slower average speed and still lengthy average border-crossing time due to customs control and long waiting in line for Pakistan: Torkham and Chaman BCPs continued as two of the most time-consuming nodes monitored by the CPMM. A positive step was the implementation of 24/7 operations at Torkham, which immediately reduced the long waiting times at this high-traffic BCP. Pakistan took robust actions to improve the environment for transit trade, yet still faced severe challenge in reducing structural barriers for road transport that keep costs high.

Tajikistan. Average border-crossing costs decreased in 2019, but all other indicators showed a less encouraging trend. Panji Poyon remained a challenging BCP in terms of long waiting times for vehicles arriving from Afghanistan. Tajikistan began preparing for the Transports Internationaux Routiers (International Road Transports) or TIR Electronic Pre-Declaration, including its integration into Tajikistan's national single window system. In 2019, Tajikistan also acceded to the electronic Convention on the Contract for the International Carriage of Goods by Road.

Turkmenistan. CPMM data showed largely deteriorating indicators for Turkmenistan, with higher average time and cost to cross BCPs, and no significant increase in speed. Sarahs and Farap BCPs, which serve transit traffic, were adversely affected by United States (US) sanctions against Iran in 2019, and continued to report elevated time and cost in comparison to other BCPs in the region.

Uzbekistan. Diverging performance for road and rail transport was observed for 2019 in Uzbekistan. While average border-crossing time for road transport decreased, time for rail transport increased. Average border-crossing cost increased for road BCPs, but decreased for rail. On the other hand, total average transport cost for road fell, while that of rail rose. Speeds for road remained the same, yet for rail showed mixed performance. Uzbekistan continued to make progress in trade facilitation reform, including establishment of the Ministry of Transport, and continued support to its well-managed national rail network.

\section{Case Study}

The CPMM 2019 report explores the common ground shared by the CAREC CPMM and the World Customs Organization time release study (TRS) tools, which both seek to measure the time and cost of specific trade facilitation activities with the ultimate aim of better informing government and trade-related entities of priority reform and modernization steps. The experience and findings of TRS activities completed 
by Georgia Revenue Service in 2013 and 2016 are discussed and compared against the findings of the 2019 CPMM data for Georgia. Both the TRS and CPMM tools covered Sarpi, Poti, and Tsiteli Khidi BCPs.

Comparative analysis showed similar values and findings for border-crossing performance, and both studies show efficient border-crossing procedures by Georgia as a result of its one-stop service. While the CPMM proved advantageous in measuring a broader scope of activities and BCPs, the TRS demonstrated a capacity for deeper analyses of issues within the confines of a BCP. The study also identified some notable complementarities, such as (i) inputs for scoping, (ii) process mapping, (iii) insights on customs controls and operations, and (iv) validation and verification. 


\section{Introduction}

\section{Background}

The Corridor Performance Measurement and Monitoring (CPMM) mechanism is an empirical tool designed by the Central Asia Regional Economic Cooperation (CAREC) Program to assess the efficiency of its six priority transport corridors (Figure 1.1). ${ }^{1}$ The CAREC corridors link the region's key economic hubs to each other, and connect landlocked CAREC countries to Eurasian and global markets. ${ }^{2}$

The CPMM aims to (i) identify the causes of delay and unnecessary cost to cargo moving along the links and nodes of each CAREC corridor, including at border-crossing points (BCPs) and intermediate stops; (ii) help national CAREC authorities determine how to address identified bottlenecks; and (iii) assess the impact of regional cooperation initiatives implemented along the CAREC corridors by member countries. ${ }^{3}$

Launched in 2009, the CPMM methodology and data collection process captures a range of ground-level information by measuring and recording actual cargo shipments along CAREC corridors and at 36 pairs of BCPs, identified and prioritized by CAREC member countries. The methodology comprises a four-phased approach summarized in Figure 1.2 and elaborated on in Appendix 1 . An established pool of national freight forwarder and transport carrier partners collects the data along the corridors and at the BCPs. ${ }^{4}$

The CPMM evaluates a set of trade facilitation indicators (TFIs) to illustrate the overall annual performance and efficiency of the CAREC corridors. ${ }^{5}$ Measured over time and across corridors, the indicators provide a comparative picture that allows the assessment and validation of impacts of transport and trade initiatives in the region. The four aggregate TFIs are:

(i) TFI1: Time taken to clear a BCP. This TFI refers to the average length of time (in hours) taken to move cargo across a border from the entry to exit points of a BCP. The entry and exit points are typically primary control centers where customs, immigration, and quarantine are handled. Along with the standard clearance formalities, this measurement includes waiting time, unloading and loading time, time taken to change rail gauges, and other indicators. The intent is to capture both the complexity and the inefficiencies inherent in the border-crossing process.

(ii) TFI2: Cost incurred at a BCP. This is the average total cost, in United States (US) dollars, of moving cargo across a border from entry to exit of a BCP. Both official and unofficial payments are included.

(iii) TFI3: Cost incurred to travel a corridor section. This comprises average total costs, in US dollars, incurred for one unit of cargo traveling along a corridor section within a country or across borders. One unit of cargo refers to a cargo truck or train carrying 20 tons of goods. A corridor section is defined as a stretch of road 500 kilometers $(\mathrm{km})$ long. Both official and unofficial payments are included. However, in practice due to data collection constraints, transport cost figures reported in the CPMM refer to transport rates for trucks, or railway tariffs for trains. ${ }^{6}$

\footnotetext{
The CAREC Program is a partnership of 11 countries-Afghanistan (AFG), Azerbaijan (AZE), the People's Republic of China (PRC), Georgia (GEO), Kazakhstan (KAZ), the Kyrgyz Republic (KGZ), Mongolia (MON), Pakistan (PAK), Tajikistan (TAJ), Turkmenistan (TKM), and Uzbekistan (UZB)working together to promote development through cooperation, leading to accelerated economic growth and poverty reduction: www.carecprogram.org.

2 The CPMM annual report is a technical document and, for the benefit of readers, it includes standard explanations and definitions, such as Chapter 1 and some of the appendixes.

A detailed description of each CAREC corridor is found at www.carecprogram.org/?page_id=20.

The national forwarder and carrier partners for 2019 are listed in Appendix 2.

The TFIs are explained in detail in Appendix 3, including statistical derivation.

"Transport cost" is viewed from the perspective of the shipper or receiver. It represents the market rate paid to move the cargo, rather than the carrier's cost of providing the service.
} 


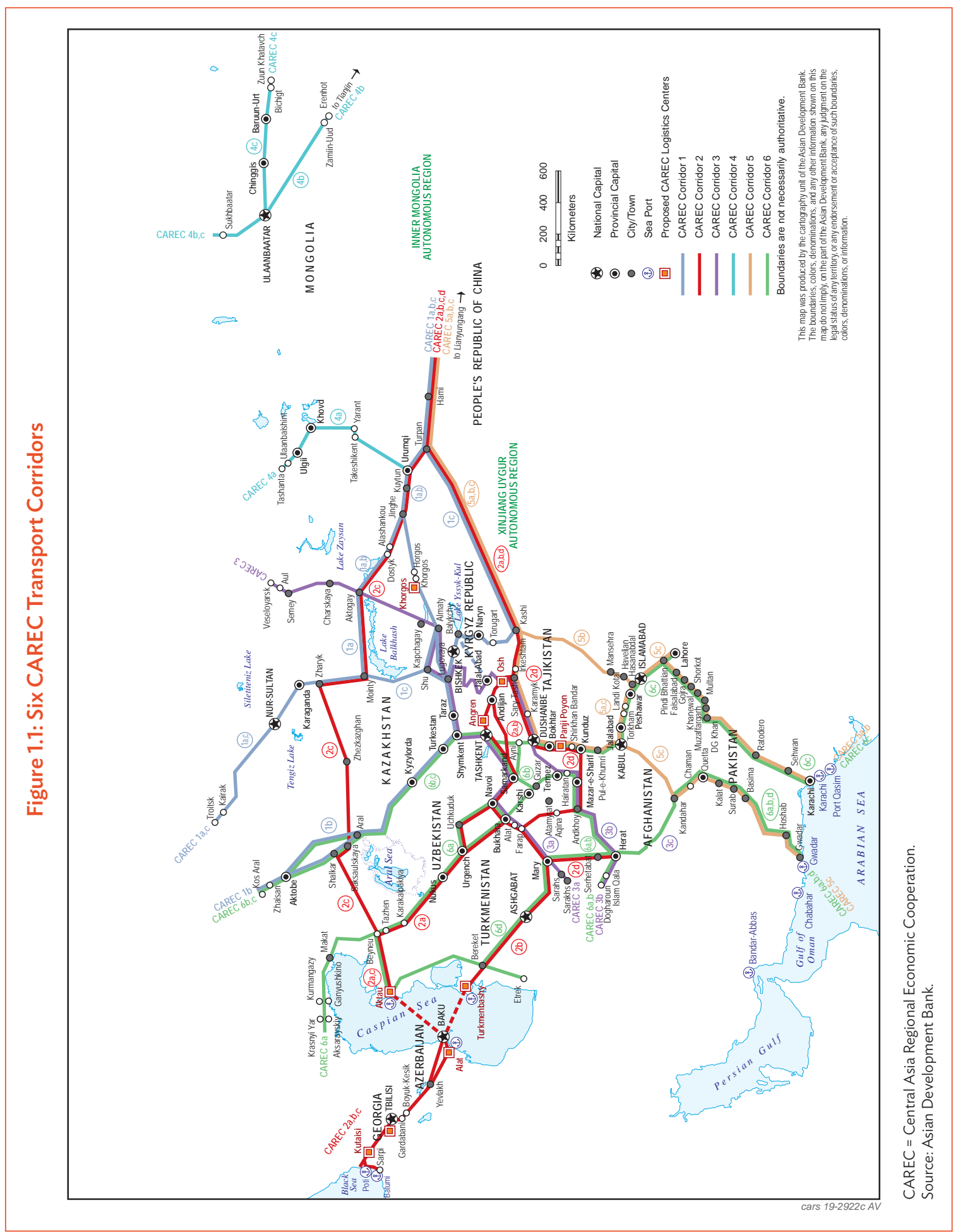


Figure 1.2: Corridor Performance Measurement and Monitoring Methodology

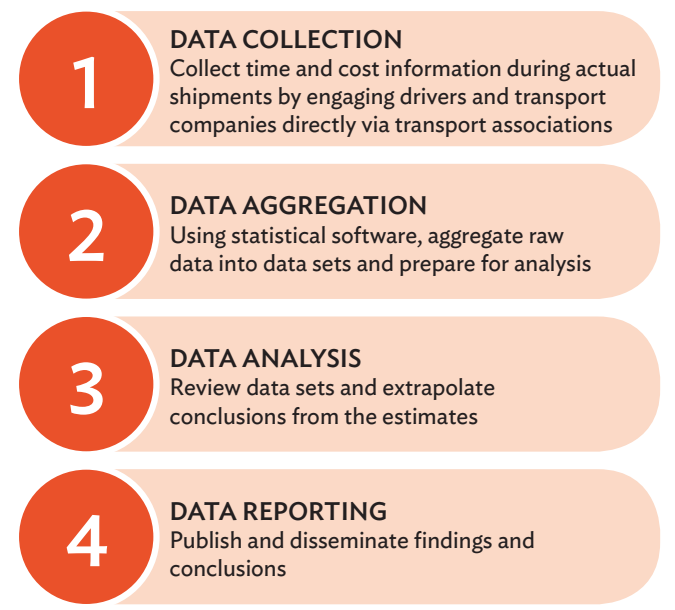

Source: Asian Development Bank.

(iv) TFI4: Speed to travel along CAREC corridors. This is the average speed, in kilometers per hour $(\mathrm{km} / \mathrm{h})$, at which a unit of cargo travels along a corridor section within a country or across borders. A unit of cargo refers to a cargo truck or train carrying 20 tons of goods, and a corridor section refers to a stretch of road $500 \mathrm{~km}$ long. Speed is calculated by dividing the total distance traveled by the duration of travel. Distance and time measurements include border crossings.

The CPMM uses two measures of speed: speed without delay (SWOD) and speed with delay (SWD). SWOD is the ratio of the distance traveled to the time spent by a vehicle in motion between origin and destination (actual traveling time). SWD is the ratio of distance traveled to the total time spent on the journey, including the time the vehicle was in motion and the time it was stationary. Under the CPMM, all activities that delay (customs controls, inspections, loading and unloading, and police checkpoints, among others) are recorded by drivers. SWOD represents a measure of the condition of physical infrastructure (such as roads and railways), while SWD is an indicator of the efficiency of BCPs along the corridors.

Time and cost indicators are also measured by activity at CAREC BCPs and other intermediate stops, such as toll booths, security inspections, and others, to help identify not only the location, but also the nature of delay at stops along a given corridor.?

Central to the CPMM's success and sustainability are:

(i) Private sector participation. National transport associations are formally engaged to train selected national transport operators or freight forwarders to use the CPMM tool, and to gather and record data. Each data sample reflects a bona fide cargo movement through the CAREC transport corridors of Central Asia.

(ii) Fact-based and data-driven conclusions. CPMM data are derived from actual transport movements and are submitted monthly by national transport associations in each CAREC country. The findings are aggregated and analyzed quarterly and annually. Over an extended period, the CPMM tool shows whether time and cost performances are improving or deteriorating.

Activities encompass all anticipated checks and procedures, both at BCPs and at intermediate stops along the transit corridor, and are listed in Appendix 4. A list of CAREC BCPs covered by the CPMM is in Appendix 5. 
(iii) Customized for landlocked countries. As most CAREC member countries are landlocked, their time and cost transport performance cannot be compared on an equal footing against countries that have seaports. CPMM methodology focuses on road and rail transport, the two dominant transport modes in Central Asia. Particular emphasis is given to border-crossing time and cost, which are frequently identified as the main cause of delay in cross-border cargo movement. In short, the CPMM is customized to meet the physical context of CAREC member countries, aligned with the CAREC corridors. 


\section{Key Results}

In this chapter, analysis of CPMM data collected throughout 2019 reports the latest TFIs for both road and rail transport at selected $\mathrm{BCPs},{ }^{8}$ and along the CAREC corridors. ${ }^{9}$ It provides an overview of the regional and local developments in the CAREC region, followed by performance evaluation of the four TFIs and the six CAREC Corridors.

\section{Trade Facilitation Indicator Results for 2019: Road Transport}

Analysis of 2019 CPMM data showed that one out of the four TFIs for road transport improved compared to results for 2018, one remained unchanged, while two underperformed. The average border-crossing times remained largely unchanged while average costs increased. Average speed to travel the CAREC corridors fell, but so did the total average cost. Detailed results are presented in Chapter 4.

TFI1: Time taken to clear a border-crossing point (Figure 2.1). Average border-crossing time averaged 12.2 hours, largely unchanged from 2018. However, the long-term median displayed a noticeable rise, attributed to the steady increase observed at Dautota-Tazhen (KAZ-UZB), Yallama-Konysbaeva (UZBKAZ), and Alat-Farap (UZB-TKM) BCPs. Karasu BCP (on the Kazakhstan border with Kyrgyz Republic) showed a spike in 2019 due to long delays associated with unofficial collections at the border. Recent additions of two BCPs (Torghondi in Afghanistan and Tsiteli Khidi in Georgia) also added to the increase of median border-crossing times.

TFI2: Cost incurred at border-crossing clearance (Figure 2.2). The average border-crossing cost was estimated at $\$ 162$ in 2019, a slight increase from $\$ 155$ in 2018. The most costly BCPs were identified along subcorridor $1 \mathrm{~b}$ and all subcorridors along corridor $5.1^{10}$ The most costly BCPs in 2019 were

Figure 2.1: Time Taken to Clear a Border-Crossing Point, Road Transport

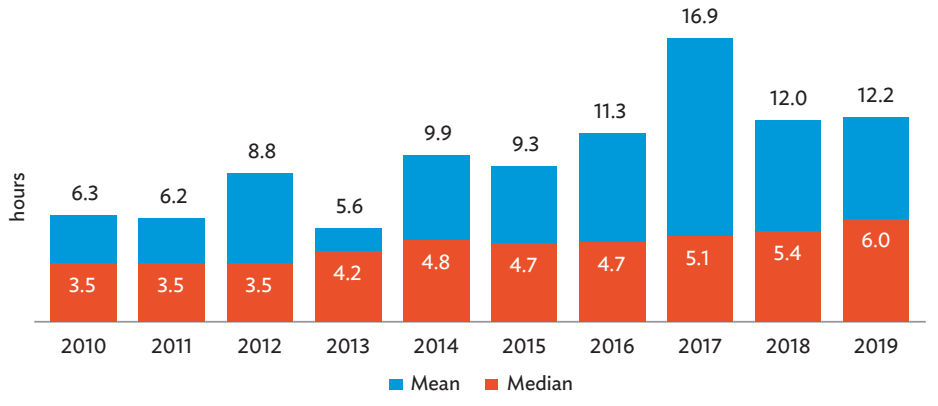

Source: Asian Development Bank.

\footnotetext{
Time and cost indicators spent at border crossing by activity and by direction of shipment at key BCPs along CAREC corridors are summarized in Appendix 7 for road transport BCPs, and in Appendix 8 for rail transport BCPs.

Summary statistics and year-on-year comparison of 2018 and 2019 trade facilitation indicators by mode of transport and by corridor are in Appendix 6.

10 Forwarders, customs brokers, shippers, and receivers frequently identify Horgos-Khorgos (PRC-KAZ) as the BCP with the highest unofficial costs. Not only do shippers and receivers frequently have to make informal payments to expedite border clearance, but carriers must also pay "protection fees" to criminal gangs at the border. Further, the declaration fee charged by Horgos customs brokers is the highest in the CAREC region.
} 
Figure 2.2: Cost Incurred at Border-Crossing Clearance, Road Transport

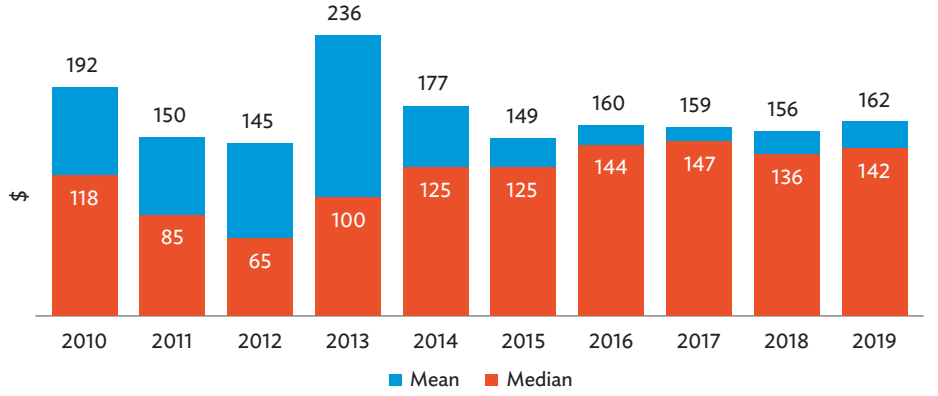

Source: Asian Development Bank.

Horgos-Khorgos (PRC-KAZ), Peshawar-Torkham (PAK-AFG), ${ }^{11}$ Shirkhan Bandar-Panji Poyon (AFGTAJ), ${ }_{12}^{12}$ Torghondi-Serkhet Abad (AFG-TKM), and Takeshikent-Yarant (PRC-MON). ${ }^{13}$ Key reasons for the high costs were customs controls and loading or unloading fees. Kuryk, a seaport terminal at Aktau handling traffic crossing the Caspian Sea, was added in 2019 to the BCPs monitored by the CPMM. CPMM data showed that the cost of acquiring permits to ship oversized equipment and machinery from Georgia to Kazakhstan contributed to the 2019 rise in border-crossing cost.

TFI3: Cost incurred to travel a corridor section (Figure 2.3). Total average transport cost to travel a corridor section in 2019 was \$901, down from $\$ 953$ in 2018 and spurred by a substantial decrease in estimated average road freight rates along corridor 4 . This was due to subcorridor $4 \mathrm{~b}$, where TFI3 saw a drop of $23.4 \%$ from $\$ 2,297$ (2018) to $\$ 1,749$ (2019). The costliest section was identified along subcorridors $5 \mathrm{~b}$ and $6 \mathrm{~d}$. Subcorridor $5 \mathrm{~b}$ is used for export of dried fruits from Kashi, PRC to Sost, Pakistan and the high road freight rate can be attributed to the high altitude and remoteness of this route. Despite the short distance from Kashi to Sost $(513 \mathrm{~km})$, the total road freight rate could be as much as $\$ 5,200$. Subcorridor

Figure 2.3: Cost Incurred to Travel a Corridor Section, Road Transport

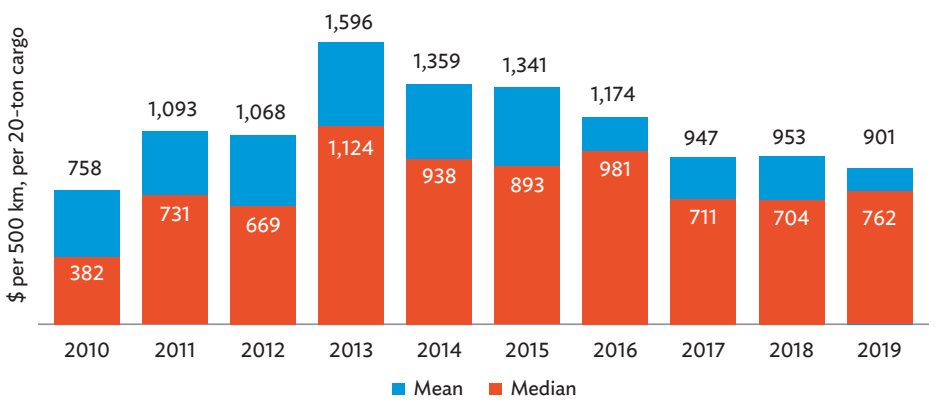

$\mathrm{km}=$ kilometer .

Source: Asian Development Bank.

11 The actual border-crossing activities are mainly conducted in Peshawar, which is the transport hub for Afghan transit trade. The truck then crosses to Torkham, the BCP that serves as the gateway for both Afghanistan and Pakistan. The names "Peshawar" and "Torkham" are used interchangeably for border crossing in this report, and to be distinct with Torkham on the Afghanistan side.

12 Panji Poyon is an international BCP located at the Afghanistan-Tajikistan border, referred to both locally and in earlier CPMM annual reports as Nizhni Pianj.

13 CPMM naming conventions identify national BCPs using the country abbreviation in parenthesis directly after the BCP names, e.g. Horgos-Altynkol (PRC-KAZ) and Horgos (PRC) 
6d serves transit shipment of agricultural produce from Quetta, Pakistan across Afghanistan to Ashgabat, Turkmenistan: the security premium assigned to trucks having to cross restive regions pushed up the road freight rate.

TFI4: Speed to travel on CAREC corridors (Figure 2.4). Both SWOD and SWD exhibited a year-on-year decrease: SWOD was 43.6 kilometers per hour $(\mathrm{km} / \mathrm{h})$, down from $46.3 \mathrm{~km} / \mathrm{h}$ in 2018; and SWD was $22.6 \mathrm{~km} / \mathrm{h}$, down from $23.4 \mathrm{~km} / \mathrm{h}$ in 2018 . Corridor 1 was the fastest while the slowest was corridor 5 . Both corridors 4 and 5 led the decrease in SWOD. Although SWD dropped slightly, the average speed remained within the long-term trend line.

Figure 2.4: Speed to Travel on CAREC Corridors, Road Transport

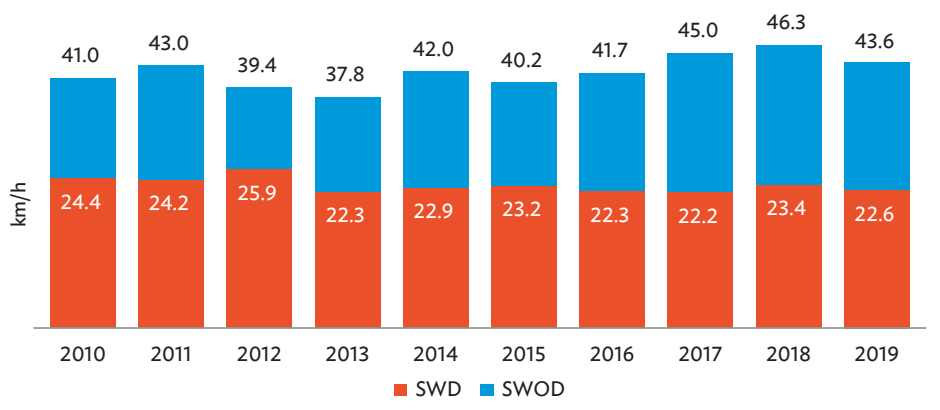

$\mathrm{km} / \mathrm{h}=$ kilometer per hour, SWD = speed with delay, SWOD = speed without delay. Source: Asian Development Bank.

\section{Trade Facilitation Indicator Results for 2019: Rail Transport}

Continuing a trend that started in 2014 , the average time to clear a BCP, cost to travel a corridor section, SWOD, and SWD have all continued to improve significantly in 2019. On the other hand, the average cost to clear a BCP remained about the same as 2018, part of a slow downtrend that began in 2011. Detailed results are in Chapter 5 .

TFI1: Time taken to clear a border-crossing point (Figure 2.5). CPMM data showed that average BCP crossing time for rail transport dropped significantly to 20.6 hours from 23.2 hours in 2018 , continuing a steady downward trend that began in 2014. Much of the improvement can be attributed to specific

Figure 2.5: Time Taken to Clear a Border-Crossing Point, Rail Transport

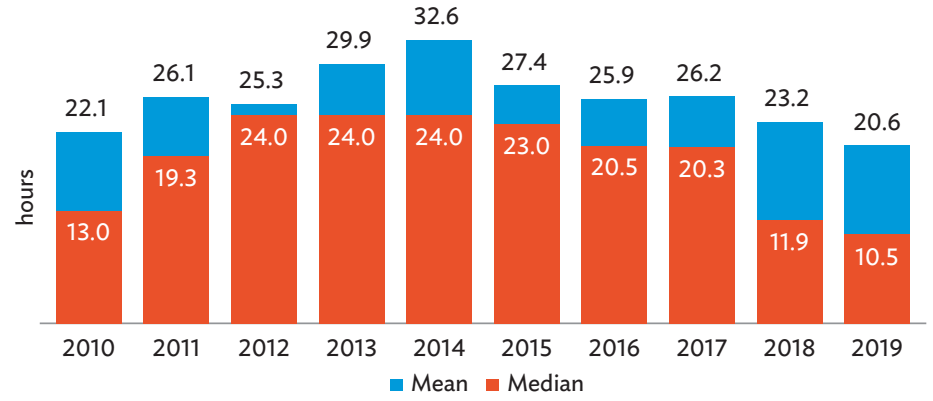

Source: Asian Development Bank. 
measures taken by the PRC, including streamlining border-crossing processes, enhancing transloading capability, and increasing the supply of flat wagons.

TFI2: Cost incurred at border-crossing clearance (Figure 2.6). The median border-crossing clearance cost for 2019 remained the same as for 2018, but the mean rose slightly during the same period. While the PRC reduced border-crossing clearance cost, this was not apparent at BCPs in other CAREC member countries: for example, both Dostyk and Altynkol BCPs in Kazakhstan saw very high expenses associated with border clearance.

Figure 2.6: Cost Incurred at Border-Crossing Clearance, Rail Transport

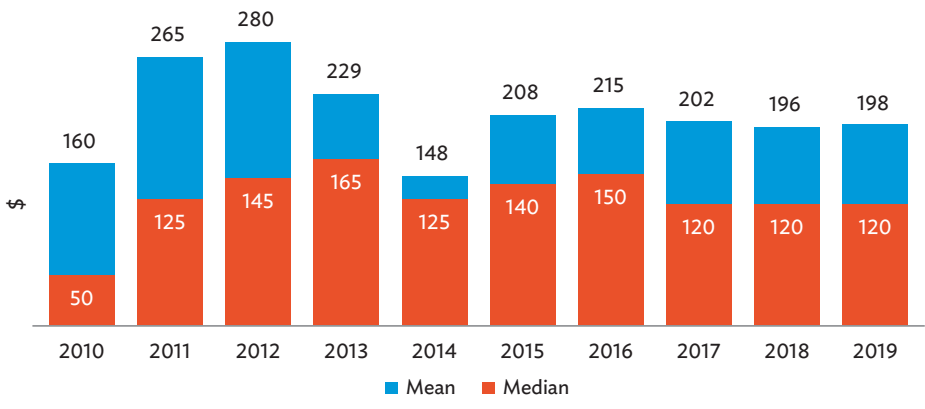

Source: Asian Development Bank

TFI3: Cost incurred to travel a corridor section (Figure 2.7). Total average transport cost dropped from $\$ 970$ in 2018 to $\$ 820$ in 2019, continuing a steady downward trend that also began in 2014, although average costs along corridor 6 remained high.

TFI4: Speed to travel on CAREC corridors (Figure 2.8). SWOD and SWD in 2019 both showed significant improvements over 2018, with SWOD jumping from $35.4 \mathrm{~km} / \mathrm{h}$ to $45.0 \mathrm{~km} / \mathrm{h}$, and SWD from $15.9 \mathrm{~km} / \mathrm{h}$ to $19.0 \mathrm{~km} / \mathrm{h}$. These improvements can be due to shorter average border-crossing times.

Figure 2.7: Cost Incurred to Travel a Corridor Section, Rail Transport

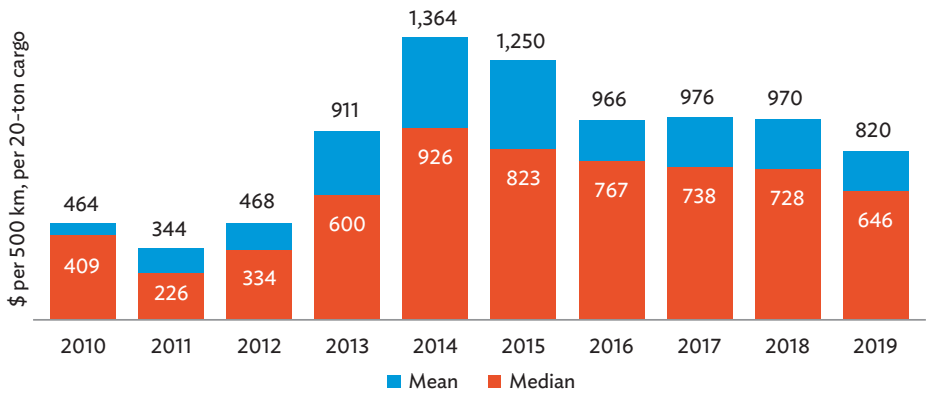

$\mathrm{km}=$ kilometer

Source: Asian Development Bank. 
Figure 2.8: Speed to Travel on CAREC Corridors, Rail Transport

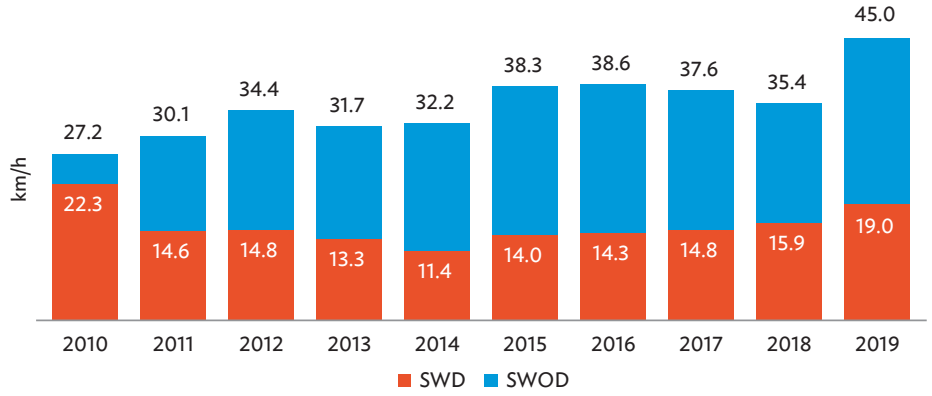

$\mathrm{km} / \mathrm{h}=$ kilometer per hour, SWD = speed with delay, SWOD = speed without delay

Source: Asian Development Bank.

\section{Trade Facilitation Indicator Trends 2010-2019}

After 10 years of sampling actual cross-border commercial shipments, the CPMM database holds rich information about transport corridor performance throughout the CAREC region. In the following section, the four CPMM TFIs are used during the period 2010-2019 to examine the key longer-term performance trends for both road and rail transport (Figure 2.9).

In general, TFI1 displayed a decline, mostly as a result of improvement in average border-crossing time for rail transport in 2019, while that of road transport remained unchanged. TFI2 has remained within the

Figure 2.9: Trend of Trade Facilitation Indicators for Combined Road and Rail Transport, 2010-2019

TFI1: Time to Clear a BCP
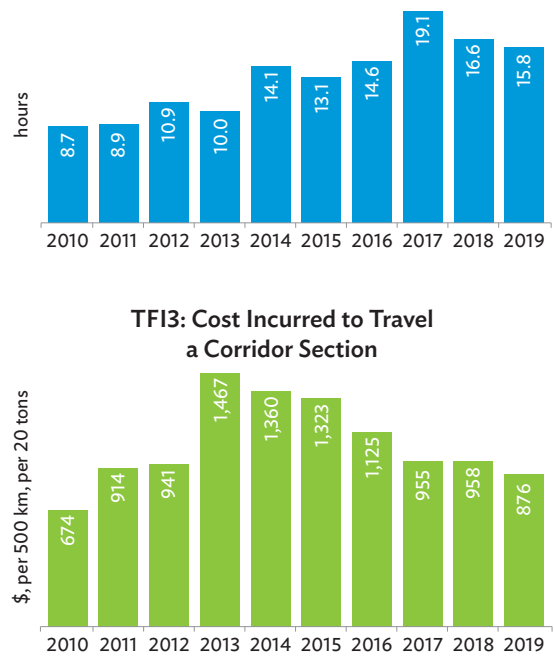

TFI2: Cost Incurred at a BCP

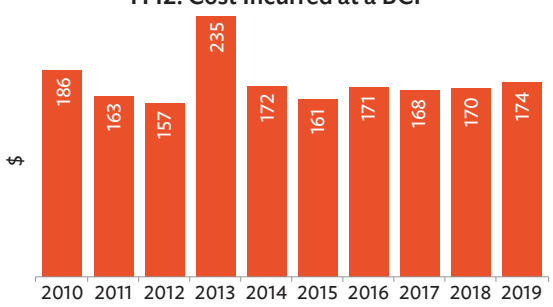

TFI4: Speed to Travel on CAREC Corridors

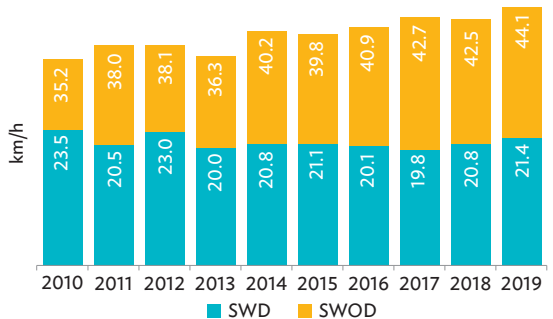

$\mathrm{BCP}=$ border-crossing point, $\mathrm{CAREC}=$ Central Asia Regional Economic Cooperation, $\mathrm{km}=$ kilometer, $\mathrm{km} / \mathrm{h}=$ kilometer per hour, $\mathrm{SWD}$ = speed with delay, $\mathrm{SWOD}$ = speed without delay, $\mathrm{TFI}$ = trade facilitation indicator.

Source: Asian Development Bank. 
same range since 2014. TFI3 reported notable reduction in the longer-term trend due to the simultaneous decrease in total average transport rates in both road and rail (Figures 2.10 and 2.11). TFI4 inched up as a result of increasing speeds in rail transport in 2019.

Corridor 1: Benefiting from infrastructure improvement initiatives, including Kazakhstan's Nurly Zhol transport infrastructure modernization program, all three subcorridors sustained SWOD over $50 \mathrm{~km} / \mathrm{h}$ in 2019. Trucks transiting the Shymkent-Kyzylorda-Aral/Aktobe sections (south and northwestern Kazakhstan) registered an average SWOD of $30-40 \mathrm{~km} / \mathrm{h}$.

Corridor 2: Trucks in the Caucasus moved at speeds beyond $40 \mathrm{~km} / \mathrm{h}$, with the Poti-Tbilisi-Tsiteli Khidi road section supporting SWOD of 40-50 km/h. From Krasnyi Most BCP to Baku, trucks moved at SWOD of more than $50 \mathrm{~km} / \mathrm{h}$.

Corridor 3: This corridor generally supported SWOD above $50 \mathrm{~km} / \mathrm{h}$, with trucks continuing to move rapidly along roads in the Uzbekistan section. The Khujand-Dushanbe section of Tajikistan improved significantly, showing a rise in estimated SWOD from 30-40 km/h in 2014 to above $50 \mathrm{~km} / \mathrm{h}$ in 2019. Sections including Panji Poyon-Dushanbe, Shymkent-Tashkent, and Angren-Osh still limited SWOD to 40-50 km/h, however, and could be further improved.

Corridor 4: Mongolia has for several years been the beneficiary of a major road rehabilitation program supported by ADB and other donor international organizations. CPMM monitoring reflects considerable improvement in speed during the period 2014-2019, with subcorridor 4b (Sukhbaatar-UlaanbaatarZamiin-Uud) supporting SWOD of 40-50 km/h, and subcorridor 4c crossing Bichigt at speeds of above $50 \mathrm{~km} / \mathrm{h}$.

Corridor 5: 2019 CPMM data for subcorridors 5a and 5b signaled deterioration in several sections and SWOD of less than $30 \mathrm{~km} / \mathrm{h}$. The route Karachi-D.I. Khan-Peshawar-Jalalabad-Kabul slowed severely due to (i) the axle load regime implemented inside Pakistan in $2019^{14}$ and (ii) the ongoing security situation in Afghanistan where trucks could be stopped by anti-government forces, especially along the TorkhamJalalabad and Kabul to Kunduz sections.

Corridor 6: The Quetta-Kandahar section suffered a decrease in SWOD to less than $30 \mathrm{~km} / \mathrm{h}$ due to the implementation of the axle load regime described in corridor 5. Other sections of corridor 6 within Uzbekistan sustained speeds of above $50 \mathrm{~km} / \mathrm{h}$ in 2019.

14 The National Highway Authority of Pakistan implemented and enforced its new axle load regime through a network of checkpoints that randomly checked the weight of trucks, leading to delay and slower driving speed. However, this regime was suspended for 1 year following strong protest by the business community as compliance significantly increased transport costs by limiting payload and requiring additional truck trips. 


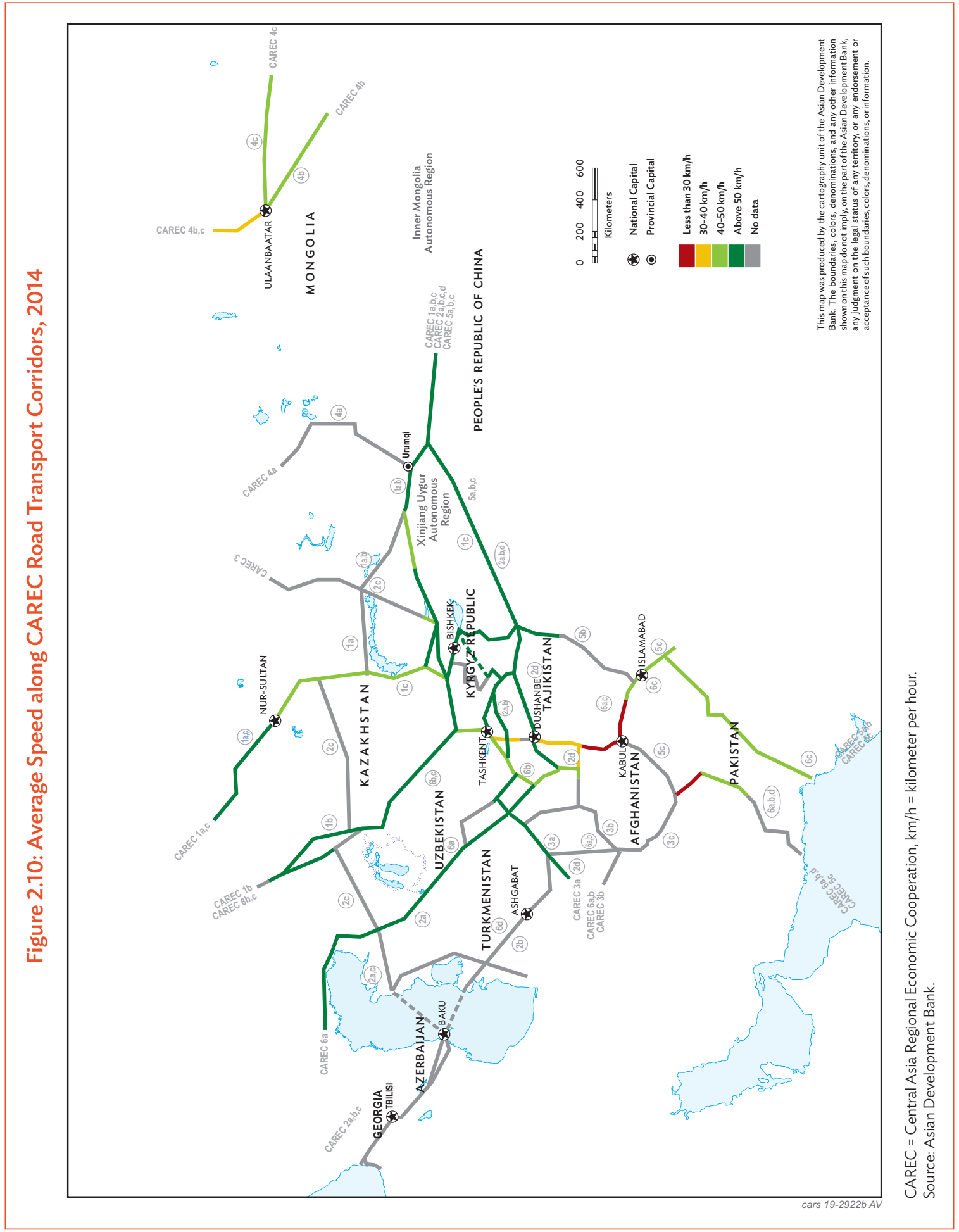




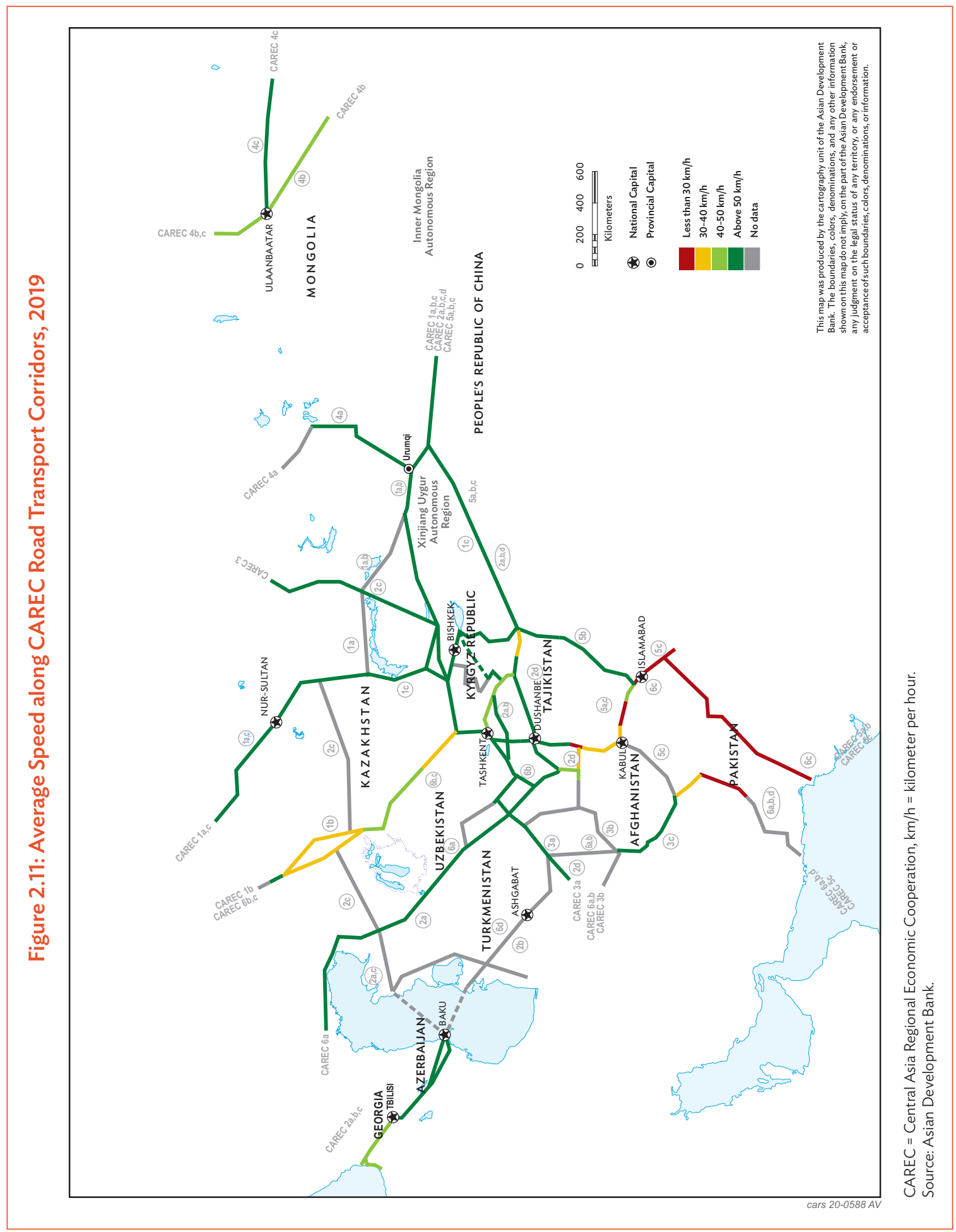




\section{Corridor Performance Measurement and Monitoring Data}

CPMM data are derived from commercial shipments that move through Central Asia. Although most of these shipments originate within CAREC member countries, some start from outside the region, for example, in Iran, the Russian Federation, or Turkey. Similarly, the final destination of most monitored shipments is within Central Asia, although some continue to more distant destinations, notably Europe and the Russian Federation.

CPMM road and rail transport time and cost data are collected by transport operators and analyzed monthly. Data relating to time is measured in hours and collected for the (i) travel time on road, railways, or water; and (ii) border-crossing time. Likewise, data relating to cost comprise (i) transport rates for trucks, or railway tariffs for trains; and (ii) border-crossing fees. The CPMM also reports on activities and locations that involve unofficial payments, such as paying additional "tea money" to border agencies at $\mathrm{BCPs}$ in exchange for preferential treatment.

\section{Data Profile}

In 2019, 15 associations (Appendix 2) in 9 countries collected 2,973 samples of cross-border shipments. The goods were carried on road (62\%), railways (26\%), and multimodal transport (12\%); perishable shipments accounted for $24 \%$ of the total and were predominantly carried on trucks (Figure 3.1). Of all samples, $17 \%$ used the TIR Carnet as a transit mechanism.

The top five categories of goods carried included vegetables products (25.9\%), machinery and mechanical appliances (20.2\%), base metals (8.1\%), textiles (7.6\%), and chemical products (5.9\%) (Figure 3.2).

Figure 3.1: Data Profile of Corridor Performance Measurement and Monitoring Samples in 2019
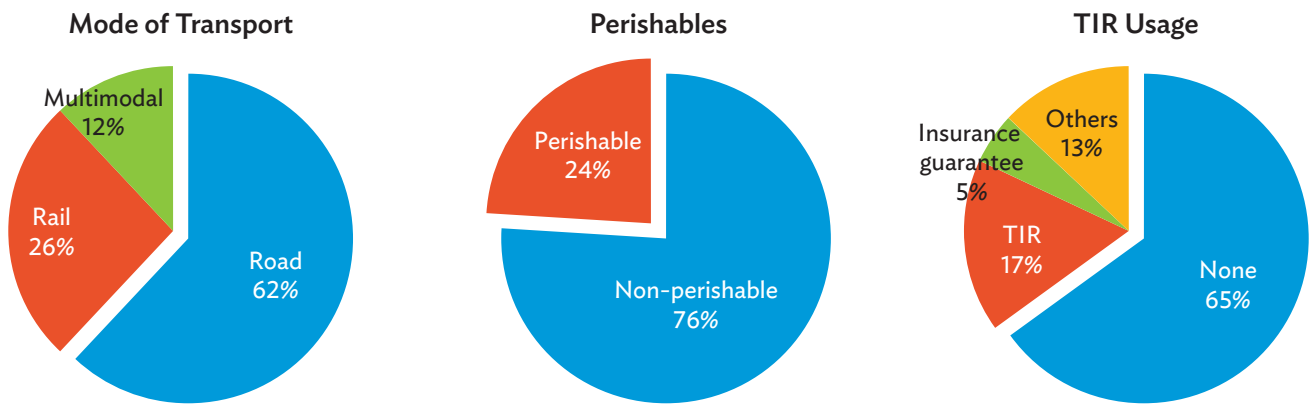

TIR = Transports Internationaux Routiers (International Road Transports).

Source: Asian Development Bank. 


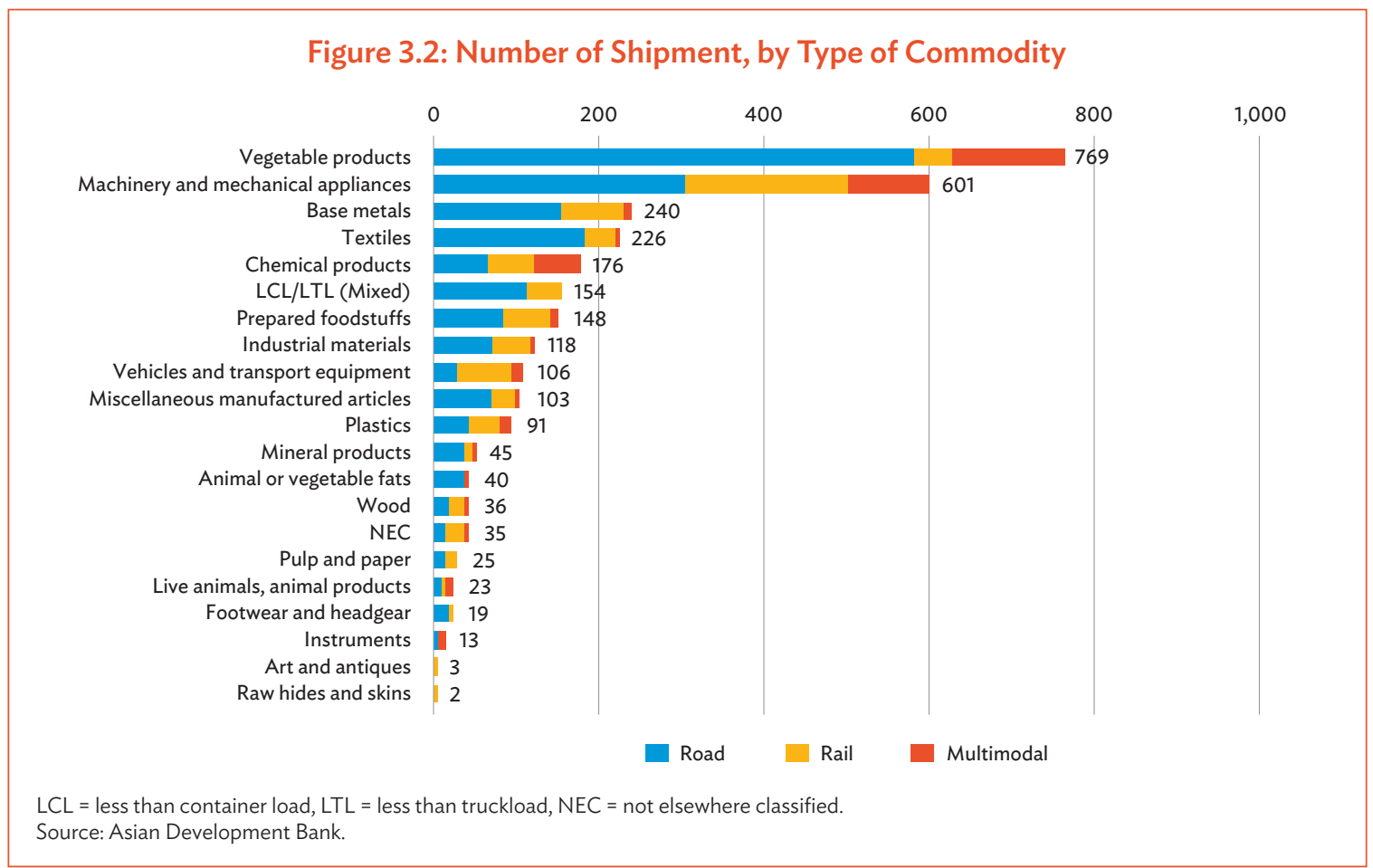

\section{Cargo Movement}

The CPMM mechanism focuses on road, railway, and multimodal transport along the six CAREC corridors and the $\mathrm{BCPs}$ along them. Each data sample gathered includes points of origin and destination which are mainly within the CAREC region, although some samples originate or terminate outside the region.

Table 3.1 lists commonly crossed key BCPs along the CAREC corridors. One BCP can appear in more than one corridor because of overlapping corridor sections.

Using 2019 CPMM data, cargo movement in each CAREC member country is summarized below. Commodity descriptions and the routes do not vary significantly year-to-year because the products are mainly staple items sent over established channels.

Afghanistan. In 2019, the CPMM captured the following types of ROAD cargo movements across Afghanistan: (i) containerized shipments from Karachi seaport, Pakistan, to Jalalabad; (ii) containerized shipments from Karachi seaport to Kandahar; (iii) transit shipments from Peshawar to Dushanbe, Tajikistan; and (iv) transit shipments from Peshawar to Tashkent, Uzbekistan. RAIL shipments included multimodal transit shipments from Quetta, Pakistan to Ashgabat, Turkmenistan or Tashkent, Uzbekistan. COMMODITIES commonly transported by road and railway were fresh fruits and vegetables.

Azerbaijan. In 2019, the CPMM captured the following types of ROAD cargo movements across Azerbaijan: (i) containerized shipments from Poti or Batumi to Baku-Aktau and which terminated in Kazakhstan, (ii) containerized shipments from Tajikistan and Uzbekistan to Georgia, and (iii) transit shipments from Turkey to Kazakhstan. No RAIL shipment data was recorded by the CPMM in 2019. COMMODITIES commonly transported by road were electrical equipment and machinery, and pharmaceuticals. 
Table 3: CAREC Corridor Alignment and Key Border-Crossing Points

\begin{tabular}{|c|c|c|}
\hline Country & CAREC Corridors & Key BCPs in CPMM \\
\hline Afghanistan & $2,3,5$, and 6 & $\begin{array}{c}\text { Hairatan, Shirkhan Bandar, Spin Buldak, } \\
\text { Torghondi, and Torkham }\end{array}$ \\
\hline Azerbaijan & 2 & $\begin{array}{c}\text { Baku (seaport), Boyuk Kesik, } \\
\text { and Red Bridge }\end{array}$ \\
\hline China, People's Republic of & $1,2,4$, and 5 & $\begin{array}{l}\text { Alashankou, Erenhot, Irkeshtan, Horgos, } \\
\text { Khunjerab, Kara-Suu, Takeshikent, Torugart, } \\
\text { and Zuun Khatavch }\end{array}$ \\
\hline Georgia & 2 & Gardabani, Sarpi, and Tsiteli Khidi \\
\hline Kazakhstan & $1,2,3$, and 6 & $\begin{array}{c}\text { Altynkol, Dostyk, Khorgos, Konysbaeva, } \\
\text { and Tazhen }\end{array}$ \\
\hline Kyrgyz Republic & $1,2,3$, and 5 & $\begin{array}{l}\text { Ak-Tilek, Chaldovar, Gulistan, Irkeshtam, } \\
\text { Karamyk, and Torugart }\end{array}$ \\
\hline Mongolia & 4 & $\begin{array}{l}\text { Altanbulag, Bichigt, Sukhbaatar, Yarant, } \\
\text { and Zamiin-Uud }\end{array}$ \\
\hline Pakistan & 5 and 6 & Chaman and Peshawar \\
\hline Tajikistan & $2,3,5$, and 6 & $\begin{array}{l}\text { Dusti, Gulistan, Karamyk, Kulma, } \\
\text { Pakhtaabad and Panji Poyon }\end{array}$ \\
\hline Turkmenistan & 2,3 , and 6 & Farap, Sarahs, and Serkhet Abad \\
\hline Uzbekistan & 2,3 , and 6 & $\begin{array}{c}\text { Alat, Dautota, Hairatan, Dustlik, Oibek, } \\
\text { Saryasia, Termez, and Yallama }\end{array}$ \\
\hline
\end{tabular}

$\mathrm{BCP}=$ border-crossing point, $\mathrm{CAREC}=$ Central Asia Regional Economic Cooperation, $\mathrm{CPMM}=$ Corridor Performance Measurement and Monitoring. Source: Asian Development Bank.

People's Republic of China. Both road and railways shipments were collected in 2019. ROAD shipments included (i) exports of consumer and industrial goods to Kazakhstan and the Kyrgyz Republic; (ii) exports of construction equipment and building materials to Afghanistan and Tajikistan; (iii) exports of mineral fuels, consumer items, construction material, and food commodities to Mongolia; (iv) exports of plastic pipes to Pakistan along subcorridor 5b; ( $v$ ) imports of coal and minerals from Mongolia along subcorridors 4a and 4c; (vi) imports of the Russian Federation's lumber along subcorridor 4b; and (vii) transit shipments of Mongolian exports to Tianjin seaport along subcorridor 4b. Sampled RAIL movements included (i) exports of consumer products to Almaty and Nur-Sultan in Kazakhstan along corridor 1; (ii) exports of machineries and equipment to Turkmenistan, crossing Kazakhstan and Uzbekistan; (iii) exports of electronics from Chongqing to Duisburg, Germany, using container express trains; and (iv) exports of glass bottles, motorcycles, and automobile spare parts from Chongqing to Ulaanbaatar, Mongolia. COMMODITIES commonly transported by road were a mixed assortment of consumer products, apparel, iron or steel articles, and electrical equipment and machinery. Commodities shipped by railway included chemicals, electrical equipment, auto parts, machinery, and plastic articles.

Georgia. All shipments through Georgia are by ROAD along subcorridor 2 and were mostly not containerized. They included (i) exports of machineries and equipment from Turkey to Central Asia, (ii) exports of industrial and consumer goods from Ukraine and other countries on vessels that berth at Poti or Batumi and are then carried on trucks to Central Asia, (iii) exports of dried fruits and nuts from Uzbekistan to Georgia (Tbilisi), and (iv) exports of cotton from Tajikistan to Georgia. These movements cross the Caspian Sea at Baku-Aktau (AZE-KAZ). There was no RAIL shipment. COMMODITIES commonly transported by road were fruits and nuts, processed food, cotton, vehicles, electrical equipment and machinery, and pharmaceuticals.

Kazakhstan. ROAD shipments included (i) imports of consumer and industrial materials from Urumqi, the PRC, to Almaty on trucks along subcorridor 1b; (ii) imports from the Kyrgyz Republic and Uzbekistan of fresh fruits and vegetables; and (iii) transit shipments of agricultural products from the Kyrgyz Republic and Uzbekistan through Kazakhstan to the Russian Federation. CPMM data captured records of RAIL 
shipments including (i) imports of vehicles and industrial goods from major PRC cities such as Chongqing and Shenzhen on trains to Almaty; (ii) imports of vehicles and consumer goods from foreign origins using ocean containers to cities in Kazakhstan; (iii) imports of chemicals, equipment, and machineries from Urumqi to Almaty and Nur-Sultan in Kazakhstan on trains along subcorridors 1a or 1b; and (iv) transit shipments of machineries and equipment from Urumqi to Uzbekistan and Turkmenistan. COMMODITIES commonly transported by road were a mixed assortment of consumer products, apparel, and electrical equipment and machinery. Those shipped by railway included consumer electronic appliances, electrical equipment and machinery, textiles, and building and construction materials.

Kyrgyz Republic. Only ROAD shipments are tracked in CPMM data samples during 2019. They included (i) import of consumer products from the PRC; (ii) import of paper from Kazakhstan; (iii) exports of fresh and dried fruits and textiles to Kazakhstan and the Russian Federation; and (iv) transit shipments of equipment and machineries from the PRC to Tajikistan. There was no RAIL shipment as the Kyrgyz rail network is very small and disjointed. COMMODITIES commonly transported by road were vegetables, fruits and nuts, small appliances, apparel, and electrical equipment and machinery.

Mongolia. CPMM data captured both road and rail transport data in Mongolia in 2019. ROAD traffic samples included (i) imports of chemicals and diesel fuel from the PRC into Mongolia, and crude oil exports to the PRC from Mongolia, crossing Bichigt along subcorridor 4c; (ii) imports of mixed consumer goods and foodstuff from the PRC to Ulaanbaatar, crossing Zamiin-Uud along subcorridor 4b; (iii) imports of consumer goods and beverages from the Russian Federation to Ulaanbaatar, crossing Altanbulag along subcorridor 4b; and (iv) exports of coal from Mongolia to the PRC, crossing Yarant along subcorridor 4c; and (v) imports of beverages, electrical equipment, and mixed cargoes crossing Borshoo, which was a new addition in 2019. All samples were transported on noncontainerized trucks. RAIL shipments included (i) imports of containerized cargoes from Japan, the Republic of Korea, and parts of the PRC, such as Tianjin to Ulaanbaatar; (ii) exports of meat and minerals in containers from Ulaanbaatar to Tianjin for reexport; and (iii) transit shipments of the Russian Federation's lumber to the PRC. COMMODITIES commonly transported by road were a mixed assortment of consumer products, foodstuff, and diesel fuel. Those shipped by railways included chemicals, electrical equipment and machinery, and plastic articles.

Pakistan. ROAD shipments included (i) exports of fruits and vegetables to Tajikistan and Uzbekistan via Afghanistan; (ii) exports of fruits and vegetables from Quetta to Ashgabat, Turkmenistan, via Afghanistan; and (iii) transit shipments of containerized cargoes to Jalalabad, or Kandahar from Karachi. There was no RAIL shipment. COMMODITIES commonly transported by road were predominantly fresh fruits and vegetables, some electrical equipment and machinery, and ceramic products.

Tajikistan. ROAD shipments included (i) imports of construction and building equipment in containers from the PRC to Dushanbe, (ii) imports of consumer and industrial products in containers from the Russian Federation to Dushanbe (crossing Kazakhstan and Uzbekistan), (iii) bilateral trade with the Kyrgyz Republic via Karamyk, and (iv) imports of fruits and vegetables from Pakistan via Afghanistan. There was no RAIL shipment tracked in 2019: the Tajik rail system is small and connects internationally via the Uzbek and Turkmen rail systems, and in 2019, was still negatively affected by embargoes imposed by Turkmenistan Railway. The reasons for these embargoes remain unclear and suggest the need for increased dialogue between the governments of Tajikistan and Turkmenistan.

Turkmenistan. In 2019, ROAD shipments included transit shipments of containerized cargoes on trucks in both directions between Iran and Uzbekistan. RAIL shipments included (i) imports of equipment and machineries from the PRC and (ii) imports of fruits and vegetables from Pakistan. COMMODITIES commonly transported by road were carpets and copper articles. Rail shipments included agricultural products, and electrical equipment, and machinery.

Uzbekistan. ROAD shipments included (i) exports of agricultural products to the Russian Federation via Kazakhstan and imports of manufactured goods and seaborn fruits through Russian ports in the 
other direction, (ii) exports of fruits and vegetables to Kazakhstan, (iii) imports of fruits and vegetables from Pakistan via Afghanistan, and (iv) transit shipments of manufactured goods and equipment from the Russian Federation to Tajikistan. RAIL shipment included transit shipment of machinery and equipment from the PRC to Turkmenistan. COMMODITIES commonly transported by road were fruits and vegetables, textiles, cooper articles, and vehicles. Those shipped by railways included electrical equipment and machinery. Government reform has reopened BCPs with neighboring countries, enabling new transport routes that are shorter and more convenient, benefiting not only Uzbekistan, but also other CAREC member countries. In addition, the government has forged transit agreements with various countries to enable Uzbek road carriers to carry more cargo to and from international locations. A good example is the transit agreement with Kazakhstan to enable Uzbek truckers to transport goods between Uzbekistan and the PRC over Kazakh roads. 


\section{Road Transport in 2019}

The 2019 CPMM TFls for road transport are detailed in Tables 4.1, 4.2, 4.5, and 4.6. On a year-to-year comparison, 2019 CPMM data showed:

(i) average border-crossing time remained stable with minimal increase from 12.0 hours in 2018 to 12.2 hours in 2019;

(ii) border-crossing cost increased from \$155 in 2018 to $\$ 161$ in 2019;

(iii) total transport cost to travel a corridor section decreased from $\$ 953$ in 2018 to $\$ 901$ in 2019; and

(iv) SWD decreased from $23.4 \mathrm{~km} / \mathrm{h}$ in 2018 to $22.6 \mathrm{~km} / \mathrm{h}$ in 2019 , and SWOD decreased from $46.3 \mathrm{~km} / \mathrm{h}$ in 2018 to $43.6 \mathrm{~km} / \mathrm{h}$ in 2019.

Results for TFls by corridor are provided in Appendix 6.

\section{Trade Facilitation Indicator 1: Average Border-Crossing Time}

Table 4.1: Average Time Taken to Clear a Border-Crossing Point

\begin{tabular}{llccc} 
& & 2018 & 2019 & $\%$ change \\
\hline TFI1 & $\begin{array}{l}\text { Time taken to clear a border-crossing } \\
\text { point (hours) }\end{array}$ & 12.0 & 12.2 & +1.4 \\
\hline
\end{tabular}

$\mathrm{TFI}=$ trade facilitation indicator.

Source: Asian Development Bank.

In 2019, CPMM data identified lengthy border-crossing times for road transport at Chaman (60.1 hours), Kuryk (44.7 hours), Peshawar (35.7 hours), and Torghondi BCPs (28.2 hours) for outbound traffic. For inbound traffic, the most time-consuming BCPs were Karasu (34.4 hours), Spin Buldak (25.3 hours), Torkham (23.5 hours), and Shirkhan Bandar (20.0 hours). Kuryk is a seaport terminal at Aktau, serving the trans-Caspian cargo movement between the Caucasus and Central Asia, and was included for the first time in the CPMM in 2019.

Corridor 5 was the most time-consuming for border crossing (largely due to customs controls and waiting in line) at an average of 28.0 hours, followed by corridor 6 at an average of 14.0 hours, which are both similar to 2018 times. Corridor 4 showed the shortest average border-crossing time of 3.9 hours.

\section{Trade Facilitation Indicator 2: Average Border-Crossing Cost}

Table 4.2: Average Cost Incurred at Border-Crossing Clearance

\begin{tabular}{|c|c|c|c|c|}
\hline & & 2018 & 2019 & $\%$ change \\
\hline TFI2 & $\begin{array}{l}\text { Cost incurred at border-crossing } \\
\text { clearance }(\$)\end{array}$ & 155 & 162 & +4.1 \\
\hline
\end{tabular}

$\mathrm{TFI}=$ trade facilitation indicator.

Source: Asian Development Bank. 
TFI2 rose in 2019 due to the steady increase of border-crossing cost in specific sections of subcorridors $5 \mathrm{a}$ and $5 \mathrm{c}^{15}$ while three BCPs-Chaman, Spin Buldak, and Torkham - showed increasing TFI2 values. In 2019, cost was also affected by activity at Karasu BCP on subcorridor 1c (located at the border between Kazakhstan and Kyrgyz Republic): Kyrgyz transport operators carrying goods from the PRC to the Russian Federation were stopped at Karasu and compelled to undergo lengthy physical examination and to pay $\$ 500-\$ 1,000$ per truck to the Kazakhstan Revenue Committee, as part of anti-smuggling operations during March-April 2019. Calculation of the land-side fees at the Kuryk seaport included customs controls and road tolls to move into Kazakhstan.

Table 4.3 illustrates the dispersion of costs incurred at BCPs along CAREC Corridors in 2019. The major sources of fees and payments were customs controls, loading and unloading, road and bridge tolls, and escort and convoy costs. The highest fee (\$316) was found along corridor 1 for loading and unloading fees, due to the need for material transfer of goods from PRC trucks to temporary warehousing at Horgos, and then to Kazakh trucks. A need for escort and convoy services was reported along corridors 2, 3, and 6 (only one sample was reported, and it cost $\$ 260$ ). Customs controls were particularly costly along corridor 5 (\$225) and corridor 1 (\$181). Road and bridge toll fees (only one sample) along corridor 3 cost $\$ 260$.

Corridor 5 was also the costliest in terms of border crossing, while corridors 1, 3, and 5 saw increased border-crossing fees compared to the previous year.

Table 4.3: Average Cost at Road Border-Crossing Points by Activity

\begin{tabular}{|c|c|c|c|c|c|c|c|c|}
\hline & \multirow[b]{3}{*}{ Road Transport } & \multicolumn{7}{|c|}{ Average Cost $(\$)$} \\
\hline & & \multirow[b]{2}{*}{ Overall } & \multicolumn{6}{|c|}{ Corridors } \\
\hline & & & 1 & 2 & 3 & 4 & 5 & 6 \\
\hline $\mathrm{i}$ & Border security and/or control & 15 & 11 & 11 & 10 & 26 & 17 & 13 \\
\hline ii & Customs controls & 105 & 181 & 51 & 24 & 73 & 225 & 66 \\
\hline iii & Commercial inspection & 27 & 63 & 21 & - & 24 & 33 & - \\
\hline iv & Health and/or quarantine & 9 & - & 7 & 7 & 3 & 10 & 10 \\
\hline v & Phytosanitary & 15 & 17 & 8 & 8 & - & 35 & 10 \\
\hline vi & Veterinary inspection & 7 & - & 69 & 6 & - & - & 6 \\
\hline vii & Visa and/or immigration & 24 & 16 & 79 & 7 & - & 43 & 12 \\
\hline viii & Transit conformity & 11 & 13 & 6 & 10 & - & - & 11 \\
\hline ix & GAl and/or traffic inspection & 8 & 5 & 18 & 4 & - & 9 & 7 \\
\hline$x$ & Police checkpoint and/or stop & 9 & - & 5 & - & - & 9 & 9 \\
\hline $\mathrm{xi}$ & Transport inspection & 12 & 18 & 12 & 8 & - & 20 & 13 \\
\hline xii & Weight and/or standard inspection & 20 & 10 & 16 & 15 & 33 & 10 & 13 \\
\hline xiii & Vehicle registration & 10 & 30 & 9 & 7 & - & - & 12 \\
\hline xiv & Emergency repair & 73 & - & 9 & - & - & 77 & - \\
\hline$x v$ & Escort and/or convoy & 108 & - & 239 & 66 & - & - & 260 \\
\hline$x v i$ & Loading and/or unloading & 114 & 316 & 67 & 8 & 137 & 98 & 107 \\
\hline xvii & Road and/or bridge toll & 26 & 25 & 81 & 260 & 12 & 9 & 9 \\
\hline xviii & Waiting and/or queue & 27 & 70 & 9 & - & 9 & 17 & 35 \\
\hline
\end{tabular}

Source: Asian Development Bank.

15 Cost estimates are derived by summing fees and payments for each border-crossing activity at the BCP, to estimate the total sum paid. Moreover, "tea money" or "facilitation fees" outside of the official amount to be paid were included. 
The CPMM analyzed unofficial payments in the CAREC region (Table 4.4). ${ }^{16}$ The same rent-seeking behaviors were observed during 2019 as in 2018 in the following activities, ranked by likelihood of occurrence: (i) vehicle registration (52\%), (ii) phytosanitary activities (30\%), (iii) health and quarantine (29\%), (iv) customs controls (25\%), and (v) transport inspection (23\%). While the likelihood of having to make unofficial payments for vehicle inspection, and health and quarantine controls decreased marginally, it was slightly more likely in 2019 than 2018 that similar payments would be required for phytosanitary activities, transport inspection, and customs control. In terms of the magnitude of unofficial payment per truck, the largest sums were taken during (i) customs controls (\$92), (ii) commercial inspection (\$18), and (iii) loading and unloading (\$10).

Table 4.4: Estimated Unofficial Fees Paid per Activity for Road Transport in 2019

\begin{tabular}{|c|c|c|c|c|c|c|c|c|c|}
\hline & \multirow[b]{3}{*}{ Road Transport } & \multirow{3}{*}{$\begin{array}{l}\text { Likelihood } \\
(\%)\end{array}$} & \multicolumn{7}{|c|}{ Average $(\$)$} \\
\hline & & & \multirow[b]{2}{*}{ Overall } & \multicolumn{6}{|c|}{ Corridors } \\
\hline & & & & 1 & 2 & 3 & 4 & 5 & 6 \\
\hline $\mathrm{i}$ & Border security and/or control & 6 & 4 & - & 4 & - & - & - & - \\
\hline ii & Customs controls & 25 & 92 & 2 & 54 & - & 1 & 105 & 29 \\
\hline iii & Commercial inspection & 1 & 18 & - & - & - & - & 18 & - \\
\hline iv & Health and/or quarantine & 29 & 4 & 8 & 3 & 4 & - & - & 4 \\
\hline$v$ & Phytosanitary & 30 & 5 & 6 & 3 & 7 & - & - & 5 \\
\hline vi & Veterinary inspection & 6 & 2 & - & 3 & 2 & - & - & - \\
\hline vii & Visa and/or immigration & 10 & 3 & - & 4 & 2 & - & - & - \\
\hline viii & Transit conformity & 0 & - & - & - & - & - & - & - \\
\hline ix & GAl and/or traffic inspection & 0 & - & - & - & - & - & - & - \\
\hline$x$ & Police checkpoint and/or stop & 0 & 2 & - & 2 & - & - & - & - \\
\hline $\mathrm{xi}$ & Transport inspection & 23 & 5 & 6 & 4 & 6 & - & - & 6 \\
\hline xii & Weight and/or standard inspection & 21 & 5 & 10 & 4 & 5 & - & - & 6 \\
\hline xiii & Vehicle registration & 52 & 4 & 3 & 4 & 4 & - & - & 5 \\
\hline xiv & Emergency repair & 4 & 4 & - & 3 & - & - & 10 & - \\
\hline$x v$ & Escort and/or convoy & 0 & - & - & - & - & - & - & - \\
\hline xvi & Loading and/or unloading & 0 & 10 & 20 & - & - & 0 & - & 9 \\
\hline xvii & Road and/or bridge toll & 0 & 5 & - & 3 & - & 400 & - & - \\
\hline xviii & Waiting and/or queue & 0 & - & - & - & - & - & - & - \\
\hline
\end{tabular}

- = no data, GAI = Gosudarstvennya Avtomobilnaya Inspektsyya.

Source: Asian Development Bank.

\section{Trade Facilitation Indicator 3: Total Transport Cost}

Table 4.5: Average Cost Incurred to Travel a Corridor Section

\begin{tabular}{llllc} 
& & 2018 & 2019 & $\%$ change \\
TFI3 & $\begin{array}{l}\text { Cost incurred to travel a corridor } \\
\text { section }(\$ \text { per } 500 \mathrm{~km}, \text { per 20 tons) }\end{array}$ & $\$ 953$ & $\$ 901$ & -5. \\
\hline
\end{tabular}

$\mathrm{km}=$ kilometer, $\mathrm{TFI}=$ trade facilitation indicator.

Source: Asian Development Bank.

16 An unofficial payment is defined as a sum paid on top of that officially recognized by law, with the aim of gaining a favor in return. No official receipt is given, so tracking an unofficial payment is inherently difficult due to the opaque nature of the transaction. Drivers participating in the CPMM are trained to recognize unofficial payments and record them separately. Unofficial payments differ across corridors and tend to be more significant along high-traffic corridors where congestion leads to longer time waiting in line and where drivers paid "tea money" to shorten the waiting time. Unofficial payments were recorded at BCP and non-BCP locations, such as inland customs offices or when interacting with traffic police on the road. 
The average total transport cost to travel a corridor section dropped to $\$ 901$ in 2019 , its lowest for 3 years, as a result of cost reductions at Erenhot and Takeshikent BCPs on the PRC side of the PRC-Mongolia border. This achievement could be attributed to institutional changes in the PRC that incorporated the Quarantine Bureau into the General Administration of Customs on 1 May 2018, thus streamlining inspection procedures.

Despite this improvement, however, corridor 4 was still assessed as the overall costliest (approximately $\$ 1,500$ ), followed by corridor 1 (around $\$ 1,100$ ). Further analysis showed that the costliest specific corridor sections were located along subcorridors $5 b(\$ 1,921), 4 b(\$ 1,748)$, and $6 \mathrm{~d}(\$ 1,739)$.

\section{Trade Facilitation Indicator 4: Speed to Travel on CAREC Corridors}

Table 4.6: Average Speed to Travel on CAREC Corridors

\begin{tabular}{llccc} 
& & 2018 & 2019 & \% change \\
TFI4 & $\begin{array}{l}\text { Speed to travel on CAREC corridors } \\
(\mathrm{km} / \mathrm{h})\end{array}$ & 23.4 & 22.6 & -3.2 \\
SWOD & Speed without delay $(\mathrm{km} / \mathrm{h})$ & 46.3 & 43.6 & -5.9 \\
\hline
\end{tabular}

CAREC $=$ Central Asia Regional Economic Cooperation, $\mathrm{km} / \mathrm{h}=$ kilometer per hour, $\mathrm{SWOD}=$ speed without delay, $\mathrm{TFI}=$ trade facilitation indicator Source: Asian Development Bank.

SWOD suffered a drop in 2019 from $46.3 \mathrm{~km} / \mathrm{h}$ to $43.6 \mathrm{~km} / \mathrm{h}$ due to the speed reduction along corridors 4 and 5. The drop in speed could be due to the decrease of SWOD in sections along subcorridors $5 \mathrm{a}$ and $5 \mathrm{c}$. Nonetheless, the SWOD of $43.6 \mathrm{~km} / \mathrm{h}$ was in line with the 5-year trend (2015-2019) where the average SWOD was estimated at $43.4 \mathrm{~km} / \mathrm{h}$. SWD reduced slightly from $23.4 \mathrm{~km} / \mathrm{h}$ to $22.6 \mathrm{~km} / \mathrm{h}$, which was still in line with the 5-year trend (2015-2019) averaging $22.7 \mathrm{~km} / \mathrm{h}$.

Corridor 1 remained the fastest corridor for trucks, reaching average speeds of $57 \mathrm{~km} / \mathrm{h}$, followed by corridor 2 at $56 \mathrm{~km} / \mathrm{h}$. Trucks in corridor 5 moved at an average of $30 \mathrm{~km} / \mathrm{h}$, while trucks crossing other corridors attained average speeds of more than $40 \mathrm{~km} / \mathrm{h}$. In terms of SWD, corridor 1 remained the fastest $(31 \mathrm{~km} / \mathrm{h})$, followed by corridor $2(25 \mathrm{~km} / \mathrm{h})$. Corridor 5 was the slowest at $10.5 \mathrm{~km} / \mathrm{h}$. The worstperforming routes were located along corridors $5 \mathrm{a}, 5 \mathrm{c}$, and $6 \mathrm{~d}$, which also had the longest border-crossing times.

\section{Corridor Performance}

Figure 4.1 shows the relative performance of the six CAREC corridors using average border-crossing times and cost. Corridor 5 had the highest relative time and cost in 2019, which continues a trend of 6 years. ${ }^{17}$ Persistent issues were noted at Torkham (PAK-AFG), Chaman-Spin Buldak (PAK-AFG), and Shirkhan Bandar-Panji Poyon (AFG-PAK) BCPs.

\section{Corridor 1}

This corridor links East Asia to Europe by way of three subcorridors: (i) subcorridor 1a predominantly facilitates railway traffic; (ii) subcorridor $1 \mathrm{~b}$ is active for both road and rail transport, for example, on the route between Urumqi and Almaty which is heavily used by cargo trucks; and (iii) subcorridor 1c which connects the Kyrgyz Republic to international highways in Kazakhstan that link to the Russian Federation.

\footnotetext{
17 The inclusion of Pakistan in CPMM began in 2014. Introduction of the Afghanistan-Pakistan BCPs resulted in above-average border-crossing delays.
} 
Figure 4.1: Comparisons of Corridor Performance:

Average Border-Crossing Duration versus Cost, 2019

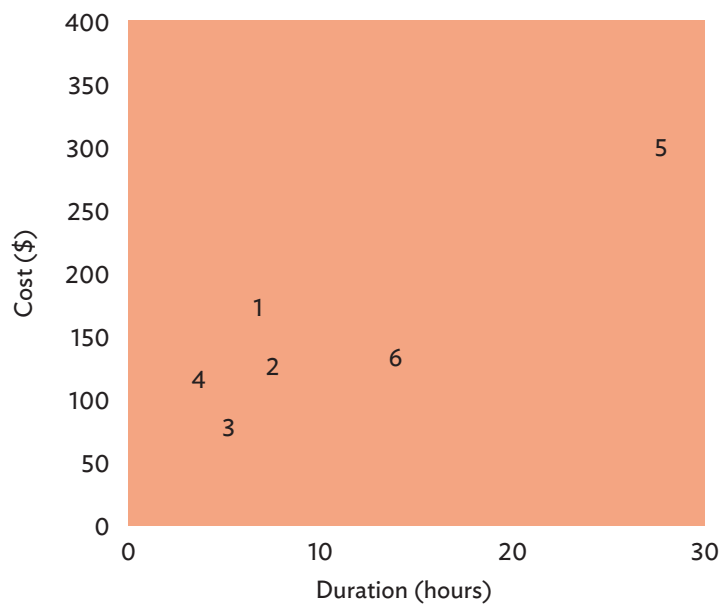

Source: Asian Development Bank.

With average border-crossing times of 7 hours along corridor 1 , and border-crossing costs of $\$ 169$ in 2019 , total transport costs were estimated at $\$ 1,092$, making it the most expensive among the six CAREC corridors, with the exception of corridor 4 . Trucks enjoyed the best speeds along corridor 1, where SWOD reached $43.6 \mathrm{~km} / \mathrm{h}$ and SWD reached $31.3 \mathrm{~km} / \mathrm{h}$.

On 25 June 2019, the General Administration of Customs of the People Republic of China declared 13 international BCPs that would specifically support TIR operations (Table 4.7). ${ }^{18}$ Although TIR entered into force in the PRC in 2016, it was only operationalized recently, and the first TIR shipment arrived in the PRC from Germany in February 2019, after traveling 7,400 km in 12 days. ${ }^{19}$ A TIR shipment sample in December 2019 showed that the border crossings from the PRC to Kazakhstan (at Horgos-Khorgos) to Germany took 32 hours. This was due to a technical problem at the PRC customs information system as well as rectification on the TIR Carnet.

Another notable development along corridor 1 in 2019 was the new checkpoint Nur Zholy established in Khorgos (KAZ) at the border with the PRC, dedicated for freight and with capacity to handle 2,500 vehicles daily in both directions. Nur Zholy has a modern logistics center, automatic weight measurement, and vehicle inspection system, as well as parking space for 200 trucks. Although Nur Zholy only commenced operations in September 2019, the 2018 CPMM estimated that inbound trucks clearing the border at Nur Zholy enjoyed shorter border-crossing times compared to Khorgos in the past -1 hour for customs control and 2 hours for time spent waiting in line.

\section{Corridor 2}

Corridor 2 is an important passageway for regional east-west trade linking the economies of East Asia to Central Asia, the Caucasus, and the Mediterranean, with the PRC in the east and Georgia in the west, passing through nine CAREC member countries. There are four subcorridors, all of which start in the PRC and ultimately link to Georgia (2a, 2b, and 2c) and Iran (2d).

Xinjiang Uygur Logistics Association (XULA) provided information on this news. XULA is a CPMM partner.

9 International Road Transport Union. https://www.iru.org/resources/newsroom/first-tir-transport-europe-china-arrives-only-12-days. 


\section{Box 4.1: Persistent Barriers to Faster Cheaper Road Transport Trade in CAREC Corridors}

Specific factors that create continuing barriers to rapid, less costly trade for Central Asia Regional Economic Cooperation (CAREC) corridors include:

(i) Mandatory transloading of vehicles. Where shipments must be transferred to a different truck before entering a foreign territory. Unlike the European Union, where trucks, goods, and people can move with minimal border formalities, Central Asian republics tend to require foreign-registered trucks, especially those from Afghanistan, the People's Republic of China, and Pakistan to stop at the border and transfer the shipment. Due to the generally modest number of containerized shipments, transloading is a complex and time and cost-consuming process.

(ii) Opaque practices and rent-seeking behavior remain a structural problem. Corridor Performance Measurement and Monitoring (CPMM) data identifies customs controls, border security, immigration procedures, and weight or vehicle inspection as hotspots for rent-seeking behavior, where sums above official stipulated payments are necessary to "expedite" or "facilitate" processes. Customs controls in corridor 5 are the most serious, particularly at Peshawar-Torkham (Pakistan-Afghanistan) and Chaman-Spin Buldak (Pakistan-Afghanistan).

(iii) Border-crossing delays lead to late shipment delivery and penalties. Shippers exposed to unpredictable delays at border-crossing points often cannot meet their expected destination arrival times and are penalized as a result. This problem is more serious in CAREC corridors 1, 5, and 6 .

(iv) Significant delay where two transport modes meet. CPMM data have often noted that where road, rail, and water transportation modes are available (such as along corridor 6 ), at the interface between two transport modes (e.g., road-rail or road-water), delays are significant. Upgrading infrastructure, use of material handling equipment, and automation would shorten the time to transfer materials.

More detailed information at the country level is found in Chapter 6.

Source: Asian Development Bank.

Table 4.7: Transports Internationaux Routiers-Enabled People's Republic of China Border-Crossing Points

\begin{tabular}{|c|c|c|c|}
\hline No. & Countries & $\begin{array}{c}\text { Number of } \\
\text { TIR-Enabled BCPs }\end{array}$ & $\begin{array}{c}\text { BCPs in } \\
\text { CAREC Corridors }\end{array}$ \\
\hline 1 & Kazakhstan & 5 & Alashankou and Khorgos \\
\hline 2 & Kyrgyz Republic & 2 & Torugart and Irkeshtan \\
\hline 3 & Mongolia & 4 & Takeshikent \\
\hline 4 & Pakistan & 1 & Khunjerab \\
\hline 5 & Tajikistan & 1 & Karasua \\
\hline
\end{tabular}

$\mathrm{BCP}=$ border-crossing point, $\mathrm{CAREC}=$ Central Asia Regional Economic Cooperation, $\mathrm{TIR}=$ Transports Internationaux Routiers. a Although Karasu BCP is not on a CAREC corridor, it falls on an important trade route for the region.

Source: Asian Development Bank.

CPMM samples in 2019 concentrated on traffic between Georgian nodes, particularly Poti seaport on the Black Sea, and Central Asia. While Georgia exported milk products and medicine; and Poti facilitated the transit shipment of pharmaceuticals, frozen foodstuff, and machineries; Central Asian republics exported dried fruits and cotton to Georgia. All shipments use TIR and are rarely containerized.

Table 4.8 shows time and cost indicators for a sample of shipments of non-containerized cargo on trucks from Poti seaport to Central Asian markets, with samples from four of the five Central Asian republics. 
Table 4.8: Key Indicators of Shipments from Poti, Georgia to Central Asia

\begin{tabular}{lrrrr} 
Countries & \multicolumn{1}{c}{ KAZ } & KGZ & TAJ & UZB \\
Routes & Poti-Uralsk & Poti-Bishkek & Poti-Dushanbe & Poti-Tashkent \\
Distance $(\mathrm{km})$ & $2,661.71$ & $5,169.00$ & $3,325.20$ & $3,361.17$ \\
\hline Transit Time $(\mathrm{hr})$ & 67.92 & 104.42 & 75.63 & 82.07 \\
\hline Activities Time $(\mathrm{hr})$ & 194.23 & 350.83 & 173.58 & 296.10 \\
\hline Total Time $(\mathrm{hrs})$ & $\mathbf{2 6 2 . 1 5}$ & 455.25 & $\mathbf{2 4 9 . 2 1}$ & $\mathbf{3 7 8 . 1 7}$ \\
\hline Transport Rate $(\$)$ & $1,830.00$ & $2,280.00$ & $1,855.00$ & $1,871.67$ \\
\hline Activities Cost $(\$)$ & 709.50 & $1,139.50$ & $1,056.50$ & 722.62 \\
Total Trip Cost $(\$)$ & $2,539.50$ & $3,419.50$ & $2,911.50$ & $2,594.28$ \\
\hline SWOD $(\mathrm{km} / \mathrm{h})$ & 39.20 & 49.50 & 44.26 & 41.21 \\
\hline SWD $(\mathrm{km} / \mathrm{h})$ & 11.33 & 11.35 & 13.39 & 10.40 \\
\hline Transport Rate $(\$ / 500 \mathrm{~km})$ & 343.92 & 220.55 & 278.92 & 278.43 \\
Activities Cost $(\$ / 500 \mathrm{~km})$ & 133.69 & 110.22 & 158.86 & 107.37 \\
Total Trip Cost $(\$ / 500 \mathrm{~km})$ & 477.61 & 330.77 & 437.78 & 385.80 \\
\hline
\end{tabular}

$\mathrm{hr}=$ hour, $\mathrm{KAZ}=$ Kazakhstan, $\mathrm{KGZ}=$ Kyrgyz Republic, $\mathrm{km}=$ kilometer, $\mathrm{km} / \mathrm{h}=$ kilometer per hour, $\mathrm{SWD}=$ speed with delay, $\mathrm{SWOD}=$ speed without delay, $\mathrm{TAJ}=$ Tajikistan, $\mathrm{UZB}=$ Uzbekistan.

Source: Asian Development Bank.

Turkmenistan was not included as a result of complex transit regime and visa applications for Georgian transport operators. All shipments crossed the Caspian Sea, with shipments passing through Baku and Kuryk (Aktau) seaports. Data show that a one-way shipment would take on average 10-20 days to complete. SWOD ranged between 41-50 km/h, but SWD dropped to $10-13 \mathrm{~km} / \mathrm{h}$. This was expected as the shipment had to cross the Caspian Sea for which waiting times were lengthy, and adverse weather has led to vessel delay or cancellation.

\section{Corridor 3}

This north-south corridor links the eastern part of the Russian Federation to the Middle East through Central Asia. The northern section in Kazakhstan splits into two at Merke: section 3a moves into Uzbekistan and Turkmenistan, ending in Iran; and section 3b heads south to the Kyrgyz Republic, Tajikistan, and Afghanistan, also ending in Iran.

Findings in 2019 for corridor 3 resembled those in the period 2016-2018. Comparing subcorridors $3 a$ and $3 \mathrm{~b}$ (Table 4.9), trucks moving in subcorridor $3 \mathrm{a}$ experienced longer border-crossing times and paid higher fees. In addition, the total transport cost was estimated to be higher in subcorridor $3 a$. On the other hand, the average truck speed on roads was higher in subcorridor 3a. Table 4.10 shows the average time taken to cross the border at selected corridor $3 \mathrm{BCPs}$. The BCPs along subcorridor $3 \mathrm{a}$, particularly Yallama-Konysbaeva (UZB-KAZ) and Alat-Farap (UZB-TKM) required 9-11 hours to complete border-

Table 4.9: Comparisons of Trade Facilitation Indicators between Corridors 3a and 3b in 2019

\begin{tabular}{lcc} 
Trade Facilitation Indicators & Corridor $3 a$ & Corridor $3 b$ \\
TFI1 & 10.6 hours & 3.7 hours \\
TFI2 & $\$ 114$ & $\$ 81$ \\
TFI3 & $\$ 714$ & $\$ 576$ \\
TFI4 & $21.7 \mathrm{~km} / \mathrm{h}$ & $27.1 \mathrm{~km} / \mathrm{h}$ \\
SWOD & $54.4 \mathrm{~km} / \mathrm{h}$ & $40.9 \mathrm{~km} / \mathrm{h}$ \\
\hline
\end{tabular}

$\mathrm{km} / \mathrm{h}=$ kilometer per hour, $\mathrm{TFI}=$ trade facilitation indicator, $\mathrm{SWOD}=$ speed without delay . Source: Asian Development Bank. 
Table 4.10: Comparison of Average Border-Crossing Times in Subcorridors 3a and 3b

\begin{tabular}{|c|c|c|c|}
\hline Outbound BCP & Time & Inbound BCP & Time \\
\hline \multicolumn{4}{|c|}{ BCPs in Subcorridor $3 a$} \\
\hline Yallama (UZB) & 10.0 hours & Konysbaeva (KAZ) & 12.0 hours \\
\hline Alat (UZB) & 9.5 hours & Farap (TKM) & 9.0 hours \\
\hline Sarahs $^{\mathrm{a}}(\mathrm{TKM})$ & 7.6 hours & Sarahs (TKM) & 9.0 hours \\
\hline \multicolumn{4}{|c|}{ BCPs in Subcorridor $3 b$} \\
\hline Karamyk (KGZ) & 2.1 hours & Karamyk (TAJ) & 0.6 hours \\
\hline Pakhtaabad (TAJ) & 11.0 hours & Saryasia (UZB) & 10.1 hours \\
\hline
\end{tabular}

$\mathrm{BCP}=$ border-crossing point, $\mathrm{CAREC}=$ Central Asia Regional Economic Cooperation, $\mathrm{KAZ}=$ Kazakhstan, $\mathrm{KGZ}=$ Kyrgyz Republic, TAJ = Tajikistan, TKM = Turkmenistan, $\mathrm{UZB}=$ Uzbekistan.

a Sarahs is a land BCP in Turkmenistan located at the Iranian border. The BCP in Iran is called Sarakhs. Data in Iran are not collected as Iran is not a CAREC member.

Source: Asian Development Bank.

crossing procedures. Along subcorridor 3b, trucks could pass through Karamyk relatively easily, although Pakhtaabad BCP required 10-11 hours. ${ }^{20}$

In practice, the apparent better $\mathrm{BCP}$ performance in subcorridor $3 \mathrm{~b}$ did not attract traffic to use this route. In fact, Uzbek operators were more active in subcorridor 3a, moving goods in both directions, largely because $3 a$ has a smaller number of transit countries. An Uzbek operator can move in Kazakhstan and Turkmenistan territories. On the other hand, using subcorridor 3b means a truck must cross Kazakhstan, the Kyrgyz Republic, Tajikistan, Uzbekistan, and Afghanistan. The greater number of countries and the need to transit in Afghanistan could discourage transport operators. Given this, subcorridor $3 \mathrm{~b}$ is only active for Tajik-Uzbek trade and the route is not used in its entirety, whereas subcorridor $3 a$ has active traffic along the whole section.

\section{Corrid or 4}

This trilateral corridor connects Mongolia to the Russian Federation in the north, and to the PRC in the south, and is both a trade and transit corridor vital to the economy of Mongolia. Among the three routes, subcorridor $4 \mathrm{~b}$ is most important as it serves both road and rail transport. The ErenhotZamiin-Uud (PRC-MON) BCP is a key gateway for cross-border trade, allowing Mongolia to access the Tianjin seaport in the PRC.

Subcorridor 4a serves bilateral trade between the PRC and Mongolia, where goods are transferred at the Takeshikent-Yarant (PRC-MON) BCP. Agricultural produce such as fresh and dried fruits were sent from Urumqi to Bayan in 2019. At Takeshikent BCP, loading and unloading costs stood at $\$ 270$. Exporters can choose to store goods in a temporary warehouse costing $\$ 5.71$ per ton per night. Coal is exported from western Mongolia to the PRC and inspection and customs processing at the border could generally be completed within 2-3 hours (including customs controls). No serious issues were reported in time spent waiting in line, although loading and unloading operations required 2-3 hours and added significantly to the border-crossing costs.

Subcorridor 4b facilitates both road and road-rail traffic. In 2019, the 669-km Erenhot-Ulaanbaatar road option could be completed in 17 hours, with shipped commodities comprising primarily foodstuff and consumer items such as furniture and clothing. The estimated average total transport cost was $\$ 996$ and, assuming a payload of 15 tons, the price was $\$ 66.40$ per ton. The road-rail option indicated that trucks carried the goods to Zamiin-Uud, where transload onto trains was completed and trains took close to 3 days to complete the distance of $764 \mathrm{~km}$. Bulky and high-value items (e.g., communications and

20 Pakhtaabad BCP is also known locally as Dusti BCP. 
Table 4.11: Comparisons of Road and Road-Rail Shipments along Subcorridor 4b

\begin{tabular}{lcc} 
Attributes & Erenhot-Ulaanbaatar (Road) & Erenhot-Ulaanbaatar (Road-Rail) \\
Distance & $669 \mathbf{~ k m}$ & $\mathbf{7 6 4} \mathbf{k m}$ \\
\hline Transit Time & 13.78 hours & 48.76 hours \\
\hline Activities Time & 3.53 hours & 21.53 hours \\
\hline Total Time & 17.31 hours (less than 1 day) & $\mathbf{7 0 . 2 9}$ hours (approximately 3 days) \\
\hline Transport Rate & $\$ 950$ & $\$ 1,788$ \\
\hline Activities Cost & $\$ 46$ & $\$ 600$ \\
\hline Total Cost & $\$ 996$ & $\$ 2,388$ \\
\hline
\end{tabular}

$\mathrm{km}=$ kilometer.

Source: Asian Development Bank.

medical equipment) which were not time-sensitive were transported in this manner. The total freight rate was $\$ 2,388$ and, assuming an average payload of 21.6 tons, the average freight rate was estimated at $\$ 110.55$ per ton, about double that of road transport (Table 4.11).

Subcorridor $4 \mathrm{c}$ also catered to bilateral trade: equipment and less than truckload ( $L T L)$ shipments moved through Zuun Khatavch-Bichigt (PRC-MON) and no major problems were observed. Traffic is not heavy, unlike in the Erenhot-Zamiin-Uud BCP.

\section{Corridor 5}

Corridor 5 connects Central and East Asia to South Asia, providing potential routes to access all-weather seaports at Karachi, Pakistan for the landlocked countries. Three subcorridors traverse from PRC and the Central Asian republics in the north toward Afghanistan and Pakistan, terminating at Karachi, and the new seaport Gwadar.

In 2019, the CPMM again ranked corridor 5 as the most time-consuming and costly corridor for border crossing. One fundamental problem is the regulatory barriers that impede cross-border movement. For instance, Pakistan export shipments of tropical fruits to Tajikistan must transit Afghanistan, yet the shipment has to transload twice at the borders: first at Jalalabad inland customs depot in Afghanistan, and then again at Shirkhan Bandar BCP (AFG) opposite Panji Poyon BCP at the Afghanistan-Tajikistan border, onto a Tajik truck. Multiple transfers of shipments added significantly to time and cost for corridor 5.

Recognizing these and other issues, CAREC governments have attempted to resolve them. In 2019, for example, 24/7 operations were implemented at Torkham BCP (AFG-PAK) to better coordinate BCP functional working hours. ${ }^{21}$ Given the high volume of trucks crossing this BCP and a history of ad hoc border closures, both countries agreed to implement 24/7 working hours by end September 2019 to relieve congestion and lengthy periods waiting in line.22 The impact was immediate: CPMM before-andafter data analysis confirmed the improvements (Figure 4.2). CPMM estimates show the quarter-onquarter average time dropped $27 \%$ on the Pakistan side, and $41 \%$ on the Afghanistan side in Q4 2019: longer operational hours enabled processing of more trucks and avoided typical long lines before and after weekends. In the case of lasting positive progress, this initiative could be expanded at other high-traffic $\mathrm{BCPs}$, including Chaman-Spin Buldak (PAK-AFG) which also experienced long border-crossing times in 2019.

\footnotetext{
21 In Afghanistan, Friday and Saturday are nonworking days; in Pakistan, Saturday and Sunday are nonworking days.
}

22 The CPMM Annual Report 2017 described the ad hoc border closure in the first quarter of 2017 at Torkham. 


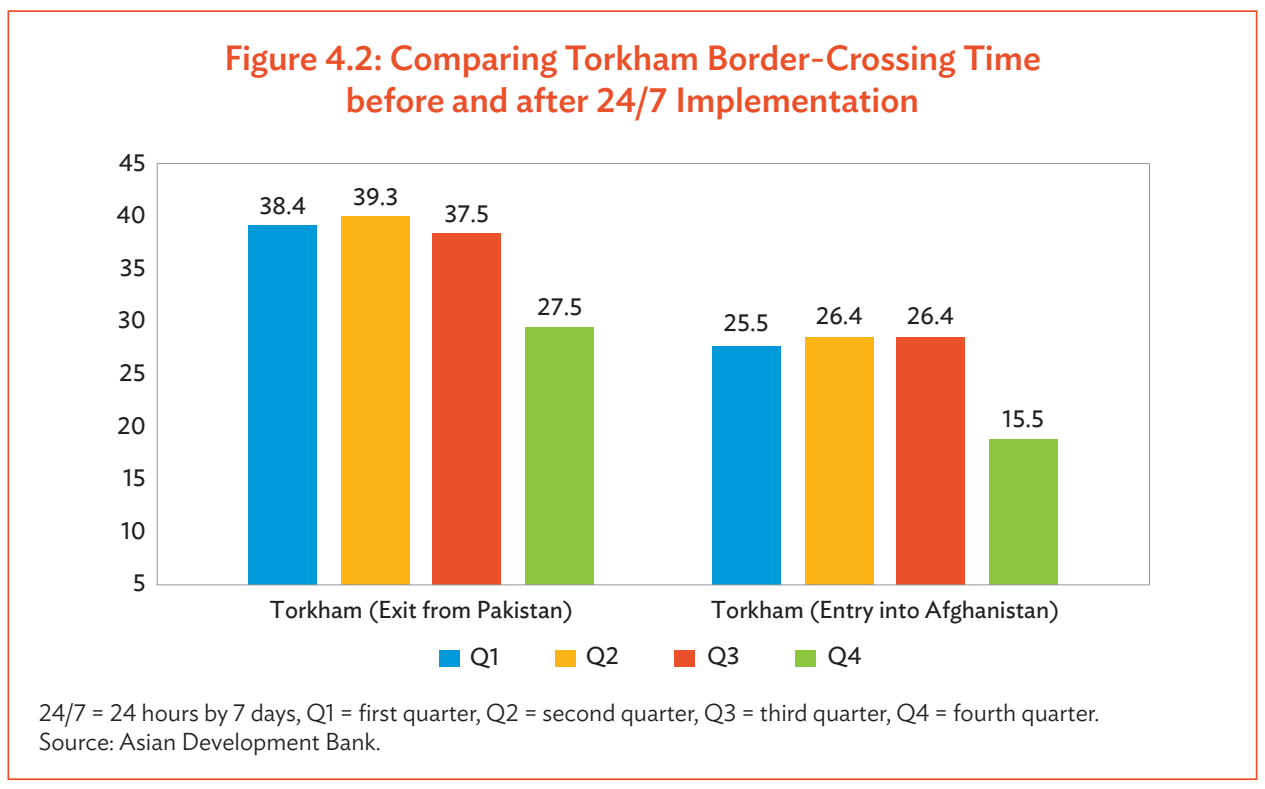

\section{Corridor 6}

Like corridor 5, corridor 6 serves interregional transit trade between Central and South Asian economies with the Caucasus, Middle East, and the Russian Federation. Uzbekistan operators actively use corridor 6 to move goods to the Russian Federation, and Pakistan agricultural producers ship their products to Uzbekistan and Turkmenistan. Unlike Corridor 5, however, corridor 6 has much multimodal potential.

On subcorridor 6a, Dautota-Tazhen (UZB-KAZ) is the key BCP located at the northwestern corner of Uzbekistan. In 2019, fruits, vegetables, and cotton were exported to the Russian Federation, and in return, a variety of consumer and industrial goods were imported into Uzbekistan through this BCP. The bordercrossing times average 7.6 hours (inbound) and 9.6 hours (outbound traffic) at Dautota; and 8.7 hours (inbound) and 11.8 hours (outbound) at Tazhen.

On subcorridor $6 \mathrm{~b}$, transit shipments from Pakistan were sent to Afghanistan and then Tashkent, Uzbekistan. From Peshawar, goods travel by road to Hairatan, where they were transferred onto barges to cross the Amu Darya river. At Termez, goods were loaded into trains and dispatched to Tashkent. The water crossing was estimated at $\$ 85-\$ 95$ per way, and the border-crossing time took an average of 32 hours.

On subcorridor 6d, transit shipments from Quetta, Pakistan crossed the Chaman-Spin Buldak (PAKAFG) BCP, and entered Turkmenistan at Torghondi-Serkhet Abad (AFG-TKM). While inbound border crossing at Spin Buldak averaged 25 hours, outbound border crossing at Chaman was the most timeconsuming BCP in 2019, averaging 60 hours. Trucks then moved to Torghondi, where the shipments were loaded onto trains, for which the time spent waiting for this operation was about 20 hours. 


\section{Rail Transport in 2019}

The 2019 CPMM TFls for rail transport are laid out in Tables 5.1-5.4. Overall, the data indicated:

(i) average border-crossing time decreased from 23.2 hours in 2018 to 20.6 hours in 2019;

(ii) average border-crossing costs saw a very slight rise from $\$ 196$ in 2018 to $\$ 198$ in 2019;

(iii) total costs decreased by $15.6 \%$, from $\$ 970$ in 2018 to $\$ 819$ in 2019; and

(iv) average SWOD in 2019 was $62.3 \mathrm{~km} / \mathrm{h}$, an improvement of $76 \%$ over average 2018 SWOD at $35.4 \mathrm{~km} / \mathrm{h}$, but speed with delay dropped to an average of $13.6 \mathrm{~km} / \mathrm{h}$ in 2019 from $15.9 \mathrm{~km} / \mathrm{h}$ in 2018.

Results for trade facilitation indicators by corridor are provided in Appendix 6.

\section{Trade Facilitation Indicator 1: Average Border-Crossing Time}

Table 5.1: Average Time Taken to Clear a Border-Crossing Point

\begin{tabular}{llccc} 
& & 2018 & 2019 & $\%$ change \\
\hline TFI1 & $\begin{array}{l}\text { Time taken to clear a border-crossing } \\
\text { point (hours) }\end{array}$ & 23.2 & 20.6 & -11.3 \\
\hline
\end{tabular}

$\mathrm{TFI}=$ trade facilitation indicator.

Source: Asian Development Bank.

Significant improvement was seen in 2019 for the average time taken to cross a BCP for rail transport, from 23.2 to 20.6 hours. This continued a general trend for the past 4 years, leaving TFI1 lower now than figures for 2010:

(i) Average delays for rail shipments along rail corridor 1 improved slightly over 2018 figures, but worsened along corridors 4 and 6. Average delays at Alashankou-Dostyk (PRC-KAZ) were the longest, followed by Horgos-Altynkol (PRC-KAZ) in corridor 1, and Erenhot-Zamiin-Uud (PRC-MON) in corridor 4.

(ii) The average delay at PRC rail BCPs dropped substantially from 22.9 hours in 2018 to 13.4 hours in 2019, continuing a steady improvement from 2014 when rail BCP delay was 38.5 hours. BCP delay for outbound traffic decreased from 14.8 hours to 11.9 hours, and for inbound traffic, from 45.8 hours to 17.3 hours. As the supply of platform wagons and the efficiency of transloading cargo from wagons of one gauge to wagons of another gauge improved, waiting times fell. The streamlining of border-crossing procedures and use of faster, more reliable material handling equipment also reduced border-crossing delays. The average delay at Kazakhstan rail BCPs also dropped from 40.6 hours in 2018 to 13.4 hours in 2019, continuing a positive trend starting in 2014 when rail BCP delay was 49.4 hours. The same factors that lowered the PRC's BCP delays also reduced Kazakhstan's BCP delays. ${ }^{23}$ Afghanistan also experienced less average delay at the Hairatan rail BCP, declining from 4.1 hours in 2018 to 3.8 hours in 2019.

23 It is important to note that the delay at Dostyk BCP, Kazakhstan is more than double the delay at the corresponding BCP on the PRC side (Alashankou). The longer delay at Dostyk can be attributed to Alashankou's larger rail yard with more operating space on the PRC side, more modern material handling equipment used by China Railways Corporation, and a better supply of PRC flat wagons. 
(iii) For Mongolia, however, average delay at rail BCPs increased from 18.1 hours in 2018 to 19.0 hours in 2019 , continuing a negative trend that started in 2017 , caused mainly by a strong uptick in cross-border traffic which faced throughput capacity constraints. The ADB-financed ZamiinUud Multimodal Logistics Center with new cargo transloading equipment was completed in mid-2019 and this additional throughput capability should relieve the capacity crunch at the original Zamiin-Uud rail station on the border.

(iv) After a steady trend of declining delay at BCPs, Turkmenistan's delay time increased slightly from 3.3. hours in 2018 to 3.5 hours in 2019. Since there is no gauge change at its BCPs (Kazakhstan and Uzbekistan railroads use the same gauge), delays are much lower. Uzbekistan also experienced increased average delay at rail BCPs from 5.6 hours in 2018 to 6.2 hours in 2019.

\section{Trade Facilitation Indicator 2: Average Border-Crossing Cost}

Table 5.2: Average Cost Incurred at Border-Crossing Clearance

\begin{tabular}{llccc} 
& & 2018 & 2019 & \% change \\
TFI2 & $\begin{array}{l}\text { Cost incurred at border-crossing } \\
\text { clearance }(\$)\end{array}$ & 196 & 198 & +1.2 \\
\hline
\end{tabular}

$\mathrm{TFI}=$ trade facilitation indicator.

Source: Asian Development Bank.

Average rail border-crossing cost along all CAREC corridors remained relatively unchanged in 2019 compared with 2018, holding largely steady since 2015.

(i) However, average BCP cost masked a substantial drop in border-crossing cost at PRC BCPs: for example, costs incurred at Alashankou BCP (PRC) decreased to only $\$ 2$ in 2019 , following a long steady decline since 2010; cost at Horgos dropped to $\$ 14$, following a steady decline since 2016; and cost at Erenhot (corridor 4) also declined to \$16, after remaining stable since 2014. This significant improvement is a result of the streamlining of trade and transport processes and elimination or reduction of associated fees.

(ii) Border-crossing cost remained high at other BCPs as well: along corridor 1, for example, cost incurred at Dostyk BCP stood at \$534 in 2019, reflecting only a slight drop from \$549 from 2018. The same cost at Altynkol BCP was $\$ 252$ in 2019, which increased slightly from 2018. Torghondi BCP on corridor 6 also showed rising border-crossing cost, increasing from $\$ 220$ in 2018 to $\$ 225$ in 2019.

\section{Trade Facilitation Indicator 3: Total Transport Cost}

Table 5.3: Average Cost Incurred to Travel a Corridor Section

\begin{tabular}{llccc} 
& & 2018 & 2019 & $\%$ change \\
TFI3 & $\begin{array}{l}\text { Cost incurred to travel a corridor } \\
\text { section }\left(\begin{array}{c}\text { \$ per } 500 \mathrm{~km} \text {, per 20 tons) }\end{array}\right.\end{array}$ & 970 & 820 & -15.5 \\
\hline
\end{tabular}

$\mathrm{km}=$ kilometer, $\mathrm{TFI}=$ trade facilitation indicator.

Source: Asian Development Bank.

A very significant reduction was seen in average cost incurred to travel a corridor section from $\$ 970$ in 2018 to $\$ 820$ in 2019 , continuing a declining trend that began in 2016 and taking average costs below 2013 levels. 
(i) The largest improvement was seen in the PRC, where average rail cost dropped $19 \%$ from $\$ 976$ in 2018 to $\$ 789$ in 2019, driven by several factors including lower express container train rates made possible by higher volumes and more balanced traffic flows, and strong local government subsidies expected to be curtailed starting 2020.

(ii) Higher volumes and lower prevailing fuel cost contributed to lower costs to travel a corridor section in Kazakhstan, which saw a decline from \$791 in 2018 to \$715 in 2019, and in Mongolia, where costs dropped from \$1,512 in 2018 to $\$ 1,373$ in 2019.

\section{Trade Facilitation Indicator 4: Speed to Travel on CAREC Corridors}

Table 5.4: Average Speed to Travel on CAREC Corridors

\begin{tabular}{llccc} 
& & 2018 & 2019 & $\%$ change \\
TFI4 & $\begin{array}{l}\text { Speed to travel on CAREC corridors } \\
(\mathrm{km} / \mathrm{h})\end{array}$ & 15.9 & 19.0 & +19.0 \\
SWOD & Speed without delay $(\mathrm{km} / \mathrm{h})$ & 35.4 & 45.0 & +26.9 \\
\hline
\end{tabular}

CAREC $=$ Central Asia Regional Economic Cooperation, $\mathrm{km} / \mathrm{h}=$ kilometer per hour, $\mathrm{SWOD}=$ speed without delay, $\mathrm{TFI}$ = trade facilitation indicator. Source: Asian Development Bank.

The average speed to travel on CAREC rail corridors increased from $15.9 \mathrm{~km} / \mathrm{h}$ in 2018 to $19.0 \mathrm{~km} / \mathrm{h}$ in 2019. The speed without delay surged from $35.4 \mathrm{~km} / \mathrm{h}$ to $45.0 \mathrm{~km} / \mathrm{h}$. These are significant improvements.

(i) The PRC's rail SWD and SWOD both achieved impressive gains, with SWD rising from $15.9 \mathrm{~km} / \mathrm{h}$ in 2018 to $20.9 \mathrm{~km} / \mathrm{h}$ in 2019; and SWOD from $50.2 \mathrm{~km} / \mathrm{h}$ in 2018 to $65.1 \mathrm{~km} / \mathrm{h}$ in 2019. This improvement follows a consistent trend that dates back to 2012 when SWD was $7.2 \mathrm{~km} / \mathrm{h}$ and SWOD was $25.7 \mathrm{~km} / \mathrm{h}$. As new dedicated high-speed passenger lines divert traditional passenger traffic from mixed-use lines, China Railways Corporation is able to raise the operating speed of freight trains. In addition, more cargoes are transported in express container trains, which run at much higher speed than lower priority conventional box wagon trains.

(ii) On the other hand, Kazakhstan's rail SWD declined from $19.9 \mathrm{~km} / \mathrm{h}$ in 2018 to $18.1 \mathrm{~km} / \mathrm{h}$ in 2019, despite a SWOD improvement from $56.4 \mathrm{~km} / \mathrm{h}$ in 2018 to $67.8 \mathrm{~km} / \mathrm{h}$ in 2019.

(iii) For Mongolia, both rail SWD and SWOD achieved gains, with SWD rising from $14.1 \mathrm{~km} / \mathrm{h}$ in 2018 to $19.1 \mathrm{~km} / \mathrm{h}$ in 2019; and SWOD from $20.9 \mathrm{~km} / \mathrm{h}$ in 2018 to $24.1 \mathrm{~km} / \mathrm{h}$ in 2019.

(iv) Uzbekistan's rail SWD declined from $14.0 \mathrm{~km} / \mathrm{h}$ in 2018 to $10.5 \mathrm{~km} / \mathrm{h}$ in 2019, despite a SWOD improvement from $27.9 \mathrm{~km} / \mathrm{h}$ in 2018 to $38.2 \mathrm{~km} / \mathrm{h}$ in 2019.

\section{Corridor Performance}

The most notable development of 2019 in rail transport was the surge in PRC-Europe and PRC-Central Asia express container trains, which has prompted increased focus on rail in several CAREC member countries. For example, with about one-sixth of the block trains (including trains to Central Asia) transiting through Mongolia on corridor 4b, the Government of Mongolia is working with its Russian Federation counterparts to build a second track on the Ulaanbaatar Railway main line between Zamiin-Uud and Sukhbaatar, and to modernize its rolling stock. Azerbaijan, Georgia, and Kazakhstan are likewise keen to increase PRC-Europe freight using rail transport to promote use of the Trans-Caspian International Transport Route. ${ }^{24}$ This route is useful in serving Turkey, and Black Sea and Mediterranean littoral states.

24 The Trans-Caspian International Transport Route starts in Southeast Asia, runs through the PRC, Kazakhstan, crosses the Caspian Sea, and continues through Azerbaijan and Georgia to Turkey and southern Europe. 


\section{Box 5.1: Persistent Barriers to Faster Cheaper Rail Transport in CAREC Corridors}

Key factors that impede faster, cheaper rail transport in Central Asia Regional Economic Cooperation (CAREC) corridors include the following:

(i) Cargo transload due to gauge difference is costly and time-consuming. Break of gauge requires the transfer of cargo from one railroad to another, which is both costly and time-consuming. Cargo transload from wagons of one gauge to wagons of another gauge requires reliable material handling equipment and ample yard space. When transload capability (which can be aggravated by wagon shortage) cannot meet demand, the receiving railway has no choice, but to suspend acceptance of incoming cargo until it can clear the log jam, causing long transit delays.

(ii) Gauge difference degrades efficiency of wagon pools and increases acquisition cost of wagons. Break of gauge segregates the wagon supply pool into smaller pools that can run only within the network of a single gauge. This loss of flexibility reduces the utilization efficiency and the pooling economy. Furthermore, this division also lessens much of the procurement negotiation power and investment flexibility. Delays can occur when the receiving railway is short on wagons to which cargo from the sending railway can be transloaded, or when the receiving railway is running out of capacity to handle the incoming cargo, and temporarily suspend acceptance of trains from the sending railway.

(iii) Different documentation required among connecting railroads. The former Soviet Union railways, the People's Republic of China railways, and European railways utilize different transit documents which can lead to substantial transport delays.

(iv) Different laws, regulations, and rules govern the transport of goods among connecting railroads. Laws, regulations, and rules regarding total wagon weight, axle load limitation, wagon dimension, and cargo liability can vary significantly, which creates uncertainty - the most restrictive rail networks limit the capability of the end-to-end move.

More detailed information at the country level is found in Chapter 6.

Source: Asian Development Bank.

\section{Corridor 1}

Europe-East Asia: This corridor connects the PRC with Europe, the Russian Federation, and Central Asia. Success in securing backhaul payloads is critical for balancing the flow of containers and platform wagons along corridor 1. For example, Chongqing International Freight Forwarder Association opened a sales office near Duisburg to target PRC-bound high-value cargo that will benefit from fast express train service, with excellent results in 2019 over 2018, as shown by Duisburg to Chongqing traffic volume nearly equaling Chongqing to Duisburg. Typical backhaul cargo in the PRC includes luxury automobiles, wine, international e-commerce parcels, and personal care, and medical products. This growth in backhaul traffic lowers rail rates and improves train services which, in turn, attracts more cargo. Consequently, daily express trains are running in both directions between Chongqing and Duisburg. The combined effect of improved train performance and lower price are key drivers in a virtuous cycle, with each improvement bringing additional cargo which, in turn, drives more frequent schedules and lower rail rates. 


\section{Corridor 2}

Mediterranean-East Asia: This corridor connects the PRC and Turkey and Southern Europe via Central Asia. Transport operators from Azerbaijan, Georgia, and Kazakhstan are promoting corridor 2 development as a multimodal route that connects East and South Asia to the Caucasus and Europe. Specific initiatives, such as the Trans-Caspian International Transport Route and the Lapis Lazuli Corridor, are aligned along corridor 2. However, from an operator's perspective, this corridor has some significant issues, such as (i) the higher number of countries transited and consequent increase in BCP crossings, resulting in added clearance cost and more delays; (ii) higher waiting times due to modal change when rail schedules and ship schedules are not synchronized; (iii) the unpredictable Caspian Sea crossing schedule, port transfer time, and terminal handling fees; and (iv) generally increased complexity of the logistics chain.

\section{Corridor 3}

Russian Federation-Middle East and South Asia: Corridor 3 connects the Russian Federation and Iran via Central Asia. The volume of rail freight transported along this route is light, yet expected to grow due to the strategic importance of the port of Bandar Abbas and Iran's key economic role in the region. ${ }^{25}$ The CPMM tracks rail movements only along the corridor section within Central Asia, i.e., between Uzbekistan and Turkmenistan. In 2019, corridor 3 saw the least amount of delay in crossing the rail BCPs for each activity (e.g., 0.3 hours for customs inspection), and just 4.9 hours for all activities. This can be attributed to the absence of gauge change, as well as similar operating procedures and culture.

\section{Corrid or 4}

Russian Federation-East Asia: Corridor 4 is the Trans-Mongolian section of the Trans-Siberian Railway and in recent years, has grown substantially in importance as a transit route between Europe, the Russian Federation, Central Asia, and the PRC.

(i) Mongolia's "Transit Mongolia" initiative is showing success in subcorridor 4b, with the cost of travel declining from $\$ 1,030$ in 2018 to $\$ 720$ in 2019, and both SWD and SWOD improving. ${ }^{26}$ Table 5.5 shows impressive gains in container transit traffic from 2014 to 2018.

(ii) According to the Xinjiang Uygur Autonomous Region Logistics Association, the number of PRCEurope trains using subcorridor 4b has increased from 1,054 in 2018 to nearly 1,500 in 2019, an increase of more than 40\%. China Communication and Transport Association reported 368 PRC-Central Asia trains via subcorridor 4b in 2018, and growth is expected to continue.

(iii) The traffic flow in 2019 continued as predominantly raw material (e.g., lumber, minerals) inbound to the PRC, and consumer products, equipment, machinery, apparel, and automotive products outbound from the PRC.

Table 5.5: Transit Rail Container Traffic Direction, 2014-2018

(TEU)

\begin{tabular}{lcrrrc} 
Route & 2014 & 2015 & 2016 & 2017 & 2018 \\
PRC to the Russian Federation & 496 & 262 & 8,376 & 29,960 & 30,611 \\
Russian Federation to PRC & 85 & 3,940 & 3,871 & 14,899 & 25,094 \\
Total Containers & $\mathbf{5 8 1}$ & $\mathbf{4 , 2 0 2}$ & $\mathbf{1 2 , 2 4 8}$ & $\mathbf{4 4 , 8 5 9}$ & $\mathbf{5 5 , 7 0 5}$ \\
\hline
\end{tabular}

PRC = People's Republic of China, TEU = twenty-foot equivalent unit.

Source: Mongolia Ministry of Road and Transport Development.

25 Bandar Abbas is the preferred seaport for most Central Asian countries

26 Transit Mongolia is a major Government of Mongolia initiative to exploit its strategic location between the PRC and the Russian Federation as a "land bridge" between Asia and Europe. 
Despite generally slower transport by rail than road along corridor 4 , there are other factors that influence modal choice which manifested for bulky, high-value, and not time-sensitive cargo in corridor 4.

(i) Minimize risk of damage. Concerns over product quality drives the owner, shipper and/or receiver to opt for rail transport to ensure delivery of items with minimal risk of damage-several Mongolian truckers are small operators using antiquated vehicles (most are not secured, lockable closed vans that are weatherproof) and lack adequate insurance to pay for cargo loss and damage. CPMM samples reveal high-value cargoes, such as telecommunication equipment or medical equipment, are transported by rail for this reason.

(ii) Minimize handling for fragile cargo. Such cargo can easily be damaged during transfer from PRC to Mongolian trucks, hence, shipment is loaded in containers at origin, and then shipped by rail to Ulaanbaatar with no intermediate handling.

(iii) Cargo security and safety can be better ensured using rail transport. Controlled substances, such as highly poisonous items like sodium cyanide used in mines, are transported by rail to avoid theft or spillage at the roadside in an accident. 


\section{Country Updates}

CPMM analysis relies on consistent and comparable data across CAREC countries, despite their inherent differences. This chapter provides an update of the main developments and CPMM data at a national level for each CAREC member country to help explain the trends or resulting outcomes at the regionalor corridor-level. This country-level analysis examines the policies, regulations, infrastructure, and institutional factors that can affect corridor performance. Pertinent barriers and issues are highlighted, key developments and progress are noted, and high-level recommendations are included.

The 2019 CPMM report introduces the four TFIs at the country level, segregated by road and rail transport, and further decomposed into outbound and inbound direction for border-crossing time and costs (tables 6.1 to $6.4,6.6$ to 6.7 , and 6.9 to 6.24). These data are supplemented by average bordercrossing time and cost for BCPs along relevant CAREC corridors. Key CPMM findings, updated trends and developments, and country-specific recommendations are also provided in this chapter.

\section{Afghanistan}

\section{Key Findings}

(i) In September 2019, Afghanistan and Pakistan implemented 24/7 working hours at Torkham BCP, relieving road traffic congestion and reducing average border-crossing time for road transport to 23.5 hours from 27.6 hours in 2018. This helped lower the 2019 national average to 19.9 hours from 21.5 hours in 2018. Notwithstanding this, Afghanistan BCPs average border-crossing times remained long compared to other CAREC BCPs: for example, 25.3 hours at Spin Buldak BCP, and 20.0 hours at Shirkhan Bandar (AFG-TAJ) BCP. These delays were mostly due to customs controls, time spent waiting in line, or transloading between trucks.

(ii) As Torkham congestion was relieved, however, the Jalalabad inland customs office experienced bottlenecks as transit shipments from Pakistan had to be cleared and transferred to an Afghan operator for onward travel. Jalalabad inland customs office is not designed for $24 / 7$ operations and despite deployment of additional staff to expedite clearance, this bottleneck persisted, most markedly on Fridays (a nonworking day in Afghanistan) and Saturdays and Sundays (non-

Table 6.1: Trade Facilitation Indicators for Afghanistan

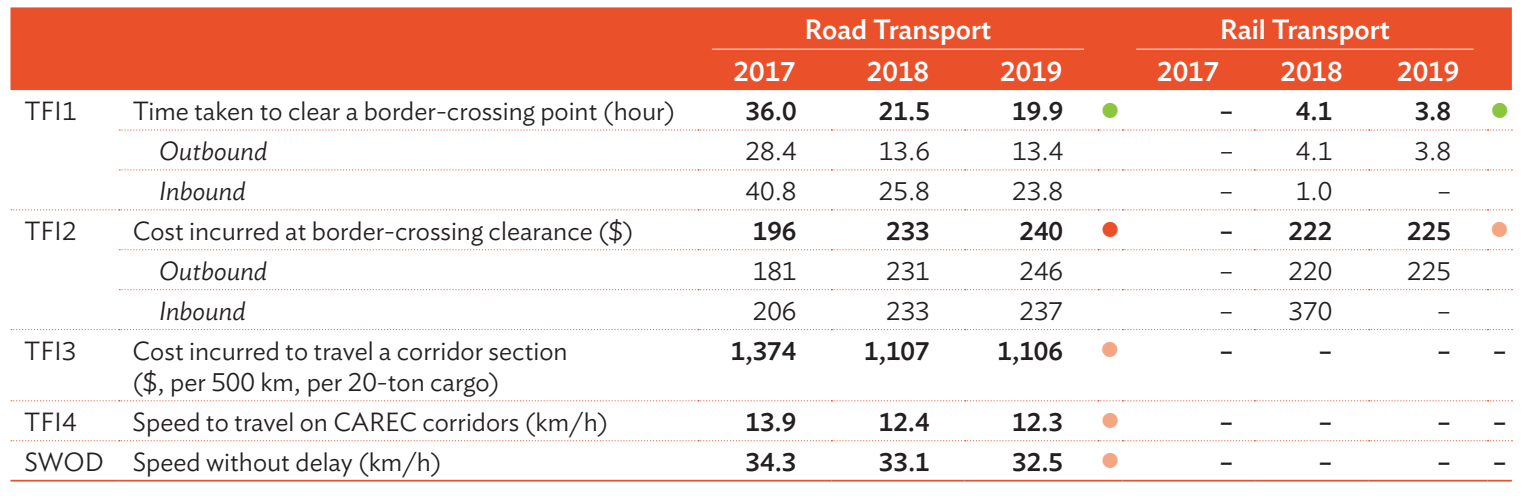

Legend: - Improved by at least 3\% - Deteriorated by at least 3\% Insignificant change [-3\% to 3\%]

- = no data, CAREC = Central Asia Regional Economic Cooperation, $\mathrm{km}=$ kilometer, $\mathrm{km} / \mathrm{h}=$ kilometer per hour, SWOD $=$ speed without delay, $\mathrm{TFI}=$ trade facilitation indicator.

Source: Asian Development Bank. 
Table 6.2: Border-Crossing Performance in Afghanistan

\begin{tabular}{|c|c|c|c|c|c|c|c|c|}
\hline \multirow[b]{2}{*}{$\mathrm{BCP}$} & \multirow[b]{2}{*}{ Corridor } & \multirow{2}{*}{$\begin{array}{l}\text { Direction } \\
\text { of Trade }\end{array}$} & \multicolumn{3}{|c|}{$\begin{array}{c}\text { Duration } \\
\text { (hours) }\end{array}$} & \multicolumn{3}{|c|}{$\begin{array}{l}\text { Cost } \\
(\$)\end{array}$} \\
\hline & & & 2017 & 2018 & 2019 & 2017 & 2018 & 2019 \\
\hline \multicolumn{9}{|l|}{ Road Transport } \\
\hline Hairatan & 3,6 & Outbound & 2.8 & 4.6 & 4.9 & 124 & 136 & 145 \\
\hline Torkham & 5,6 & Inbound & 38.2 & 27.6 & 23.5 & 219 & 243 & 258 \\
\hline \multirow[t]{2}{*}{ Shirkhan Bandar } & $2,5,6$ & Outbound & 52.6 & 11.9 & 14.2 & 154 & 295 & 331 \\
\hline & & Inbound & - & 12.0 & 20.0 & - & 418 & 392 \\
\hline Spin Buldak & 5,6 & Inbound & 48.4 & 25.7 & 25.3 & 77 & 99 & 143 \\
\hline Torghondi & 2,6 & Outbound & 30.4 & 31.5 & 28.2 & 301 & 304 & 311 \\
\hline \multicolumn{9}{|l|}{ Rail Transport } \\
\hline Hairatan & 3,6 & Inbound & - & 1.0 & - & - & 370 & - \\
\hline Torghondi & 2,6 & Outbound & - & 4.1 & 3.8 & - & 220 & 225 \\
\hline
\end{tabular}

- = no data, $B C P=$ border-crossing point.

Source: Asian Development Bank.

working days in Pakistan). This situation showed clearly that at-the-border reforms must extend and coordinate with reform at corresponding inland customs facilities, or else benefits will be minimized as new bottlenecks develop.

\section{Trends and Developments}

Afghanistan and Pakistan reactivated talks on the Afghanistan-Pakistan Transit Trade Agreement 2010, which aims to attract transit from Central Asia to seaports south of Pakistan. ${ }^{27}$

Although Afghanistan has traditionally relied on Pakistan as a gateway to international shipping routes, recent trends indicate that $70 \%$ of Afghan transit trade is now diverted through Iran, a non-CAREC member country. ${ }^{28}$ This shift has been driven by lower costs from foreign ports and more attractive security deposit and detention tariffs for transit containers from shipping lines that operate at Iran's seaports. For example, only bonded carriers in Pakistan can work with Afghan truck operators, which drives up the cost of road freight transport as the bonded carriers are required to pay $\$ 32,000$ to the Federal Board of Revenue as a guarantee deposit to receive an operating license. ${ }^{29}$ These costs are then passed on through higher fees to the truck operators, ultimately reducing the attractiveness of the transit route. Furthermore, diesel fuel in Iran ( $\$ 0.06$ per liter) is significantly less expensive than in Pakistan ( $\$ 0.86$ per liter), providing an additional edge in terms of cost competitiveness. ${ }^{30}$

The first inaugural train service from the PRC entered Afghanistan in September 2019, carrying consumer merchandise valued at $\$ 4$ million, and taking 15 days to complete the trip through Kazakhstan and Uzbekistan. The return train shipment, carrying 1,100 tons of talc in 41 containers, left Hairatan for Jiangxi province in the PRC, taking 14 days to cover the total distance of $6,700 \mathrm{~km} .{ }^{31}$ These shipments ran as trials to identify any blockages or impediments before Afghanistan, the PRC, Kazakhstan, and Uzbekistan (Kazakhstan and Uzbekistan as transit countries) begin development of a quadrilateral agreement on rail transit.

27 Dawn. 2019. Afghanistan, Pakistan resume transit trade talks. 13 July. https://www.dawn.com/news/1493807. The Afghanistan-Pakistan Transit Trade Agreement document is available at https:/customnews.pk/2014/10/20/afghanistan-pakistan-transit-trade-agreement-2010/

28 S. Shah. 2019. Pakistan loses 70pc of Afghan transit trade to Iranian ports. Pajhwok Afghan News. 19 January. https://www.pajhwok.com/en/2019/01/19/ pakistan-loses-70pc-afghan-transit-trade-iranian-ports.

29 The Federal Board of Revenue oversees customs matters. The deposit requirement was described in the Statutory Regulatory Order Number 286 in 2007. http://download1.fbr.gov.pk/sros/CustomsSROs/2007sro286.pdf.

${ }^{30}$ Estimates given by Pakistan International Freight Forwarders Association. Fuel cost data were collected in CPMM to estimate the price per liter and how much fuel was used in a road shipment.

31 XinhuaNet. 2019. First cargo train from Afghanistan to China via Uzbekistan, Kazakhstan departs. 7 September. http://www.xinhuanet.com/ english/2019-09/07/c_138374007.htm. 


\section{Recommendations}

(i) Conclude Afghanistan-Pakistan Transit Trade Agreement negotiation with Pakistan authorities to agree and confirm clear transit rules and fees. In the absence of a formal agreement, shippers and carriers face uncertainty in transit procedures.

(ii) Begin development of an Authorized Economic Operator (AEO) program, as a longer-term initiative, to help address the perceived high risk of smuggling from Afghanistan, a significant impediment to effective cross-border trade. While it is not possible to ease controls for all Afghan shippers and carriers, AEO member criteria at the necessary levels would build confidence among importing countries. Mutual recognition of AEO programs with other CAREC member countries would then facilitate simplified border crossing for Afghan transport operators. Pakistan has already started to develop its own AEO standards.

(iii) Establish green lanes at BCPs to permit certain trucks to cross the border under a simplified scheme. Green lanes could be open to local and foreign trucks under Transports Internationaux Routiers (International Road Transports) (TIR) operation, or companies under the AEO program.

(iv) Segregate cargo and passenger traffic at Torkham, the busiest BCP in Afghanistan, to ease obstruction between these two modes.

(v) Review the $24 / 7$ operation hours at Torkham and enforce the same practice at Jalalabad; consider pilot implementation at other high-traffic BCPs, where applicable.

\section{Azerbaijan}

\section{Key Findings}

(i) Azerbaijan is a key transit country for shipments between Georgia, Iran, Turkey, and other Central Asian countries. The Krasnyi Most (Red Bridge) BCP is the main border crossing between Azerbaijan and Georgia and noted a robust reduction in average border-crossing time in 2019 for road cargo, from 10.0 to 7.4 hours for outbound traffic.

(ii) Cross-border cost also declined substantially from $\$ 91$ in 2018 to $\$ 50$ in 2019.

Table 6.3: Trade Facilitation Indicators for Azerbaijan

\begin{tabular}{|c|c|c|c|c|c|c|c|c|c|}
\hline & & \multicolumn{3}{|c|}{ Road Transport } & & \multicolumn{4}{|c|}{ Rail Transport } \\
\hline & & 2017 & 2018 & 2019 & & 2017 & 2018 & 2019 & \\
\hline \multirow[t]{3}{*}{ TFI1 } & Time taken to clear a border-crossing point (hour) & - & 3.6 & 2.7 & - & - & 1.7 & - & - \\
\hline & Outbound & - & 4.4 & 1.9 & & - & - & - & \\
\hline & Inbound & - & 3.3 & 3.6 & & - & 1.7 & - & \\
\hline \multirow[t]{3}{*}{ TFI2 } & Cost incurred at border-crossing clearance $(\$)$ & - & 91.0 & 50 & - & - & - & - & - \\
\hline & Outbound & - & 79.0 & 34 & & - & - & - & \\
\hline & Inbound & - & 94.0 & 57 & & - & - & - & \\
\hline TFI3 & $\begin{array}{l}\text { Cost incurred to travel a corridor section } \\
(\$, \text { per } 500 \mathrm{~km} \text {, per } 20 \text {-ton cargo) }\end{array}$ & - & 369.0 & 23 & $\bullet$ & - & - & - & - \\
\hline TFI4 & Speed to travel on CAREC corridors $(\mathrm{km} / \mathrm{h})$ & - & 30.2 & 34.0 & $\bullet$ & - & - & - & - \\
\hline SWOD & Speed without delay $(\mathrm{km} / \mathrm{h})$ & - & 53.1 & 55.7 & $\bullet$ & - & - & - & - \\
\hline
\end{tabular}

Legend: - Improved by at least 3\%

- = no data, CAREC $=$ Central Asia Regional Economic Cooperation, $\mathrm{km}=$ kilometer, $\mathrm{km} / \mathrm{h}=$ kilometer per hour, $\mathrm{SWOD}=$ speed without delay, $\mathrm{TFI}=$ trade facilitation indicator

Source: Asian Development Bank. 
Table 6.4: Border-Crossing Performance in Azerbaijan

\begin{tabular}{|c|c|c|c|c|c|c|c|c|}
\hline \multirow[b]{2}{*}{ BCP } & \multirow[b]{2}{*}{ Corridor } & \multirow{2}{*}{$\begin{array}{l}\text { Direction } \\
\text { of Trade }\end{array}$} & \multicolumn{3}{|c|}{$\begin{array}{l}\text { Duration } \\
\text { (hours) }\end{array}$} & \multicolumn{3}{|c|}{$\begin{array}{l}\text { Cost } \\
(\$)\end{array}$} \\
\hline & & & 2017 & 2018 & 2019 & 2017 & 2018 & 2019 \\
\hline \multicolumn{9}{|c|}{ Road Transport } \\
\hline \multirow[t]{2}{*}{ Baku } & \multirow[t]{2}{*}{2} & Outbound & - & 1.6 & 0.9 & - & 111 & 23 \\
\hline & & Inbound & - & 1.2 & 0.4 & - & 61 & 34 \\
\hline \multirow[t]{2}{*}{ Krasnyi Most } & \multirow[t]{2}{*}{2} & Inbound & - & 10.0 & 7.4 & - & 19 & 23 \\
\hline & & Outbound & - & 3.2 & 4.6 & - & 92 & 63 \\
\hline
\end{tabular}

- = no data, $\mathrm{BCP}=$ border-crossing point.

Source: Asian Development Bank.

\section{Trends and Developments}

Azerbaijan's strategic location in the Caucasus region connects Central Asia to Europe and plays a critical role in facilitating transit traffic. The country is heavily reliant on energy exports, yet has very little trade with other CAREC countries except Georgia. Azerbaijan trades mainly with European countries and the Russian Federation, although Azerbaijan's strategic location could provide another route to connect the PRC with Turkey, the Black Sea littoral states, and Southern Europe.

Azerbaijan Railway is achieving good results in reform efforts and commercialization of its national railway, ${ }^{32}$ specifically:

(i) Supervisory Board approved by Cabinet of Ministers with independent members, and in compliance with corporate governance requirements for state-owned enterprises;

(ii) Investment Plan approved by the Cabinet of Ministers, and on-track implementation by Azerbaijan Railway;

(iii) key performance indicators confirmed to manage Azerbaijan Railway business;

(iv) Business Plan approved by Cabinet of Ministers and Supervisory Board, and internal quarterly reports on achievement of key performance indicators and on the implementation of reforms across Azerbaijan Railway issued by the change management unit (available on Azerbaijan Railway website);

(v) first draft of Azerbaijan's Railway Law developed and submitted to the Government of Azerbaijan for approval; and

(vi) cooperation and coordination with Georgian Railway deepened in many areas, including marketing and operations.

\section{Recommendations}

(i) Speed up enhancement of Trans-Caspian shipping capacity and port throughput capability. Unreliable scheduling, the high cost of ferry services, and the handling capacity of Baku Port cause highly variable delay times, which increases logistics costs for this port. Azerbaijan also accords high priority to the transportation of oil equipment and parts, and ordinary freight is deprioritized until these cargoes are moved through.

(ii) Develop inland dry ports. Strategically placed inland dry ports would relieve pressure on existing Caspian Sea ports and provide useful logistics functions to nearby markets and production

32 For detailed information on Azerbaijan Railway reform, see https://ady.az/en/content/index/75/73. 
centers (both industrial and agricultural). The effectiveness of inland dry ports has been proven both regionally (in the PRC) and globally to reduce logistics cost.

(iii) Develop free trade zones. Free trade zones can attract important value-added enterprises that contribute greatly to Azerbaijan's core energy industry as well as promoting new industries.

\section{People's Republic of China}

\section{Key Findings}

(i) During 2019, the average time for rail border clearance in the PRC decreased and the average cost for both road and rail border clearance improved. However, the time for outbound road shipments to clear BCPs increased, due to much longer clearance times at Erenhot BCP for shipments to Mongolia (despite the slight decline in outbound road traffic at other PRC BCPs), but the duration for inbound road shipments decreased.

(ii) SWD for road in the PRC increased from $22 \mathrm{~km} / \mathrm{h}$ in 2018 to $25.9 \mathrm{~km} / \mathrm{h}$ in 2019, while SWD for rail increased from $15.9 \mathrm{~km} / \mathrm{h}$ in 2018 to $20.9 \mathrm{~km} / \mathrm{h}$ in 2019 . SWOD for road jumped from $53.7 \mathrm{~km} / \mathrm{h}$ to $69.8 \mathrm{~km} / \mathrm{h}$ and for rail surged from $50.2 \mathrm{~km} / \mathrm{h}$ (2018) to $65.1 \mathrm{~km} / \mathrm{h}$ (2019). To accommodate the rapid increase of rail freight traffic, China Railways Corporation increased speed on the domestic sections of its PRC-Europe routes to $120 \mathrm{~km} /$ hour after upgrading the tracks and signal system in 2019.33

\section{Trends and Developments}

The PRC rail network is among the largest and busiest in the world and in 2019 the frequency of PRCEurope and PRC-Central Asia block trains surged. ${ }^{34}$ Three main gateways serve other CAREC member countries: the Alashankou-Dostyk and Khorgos-Altynkol BCPs for traffic to and from Central Asia, Europe, the Russian Federation, and the Middle East; and the Erenhot-Zamiin-Uud BCP for traffic to Mongolia, the Russian Federation, and an increasing number of PRC-Central Asia-bound block trains.

Table 6.5: Trade Facilitation Indicators for the People's Republic of China

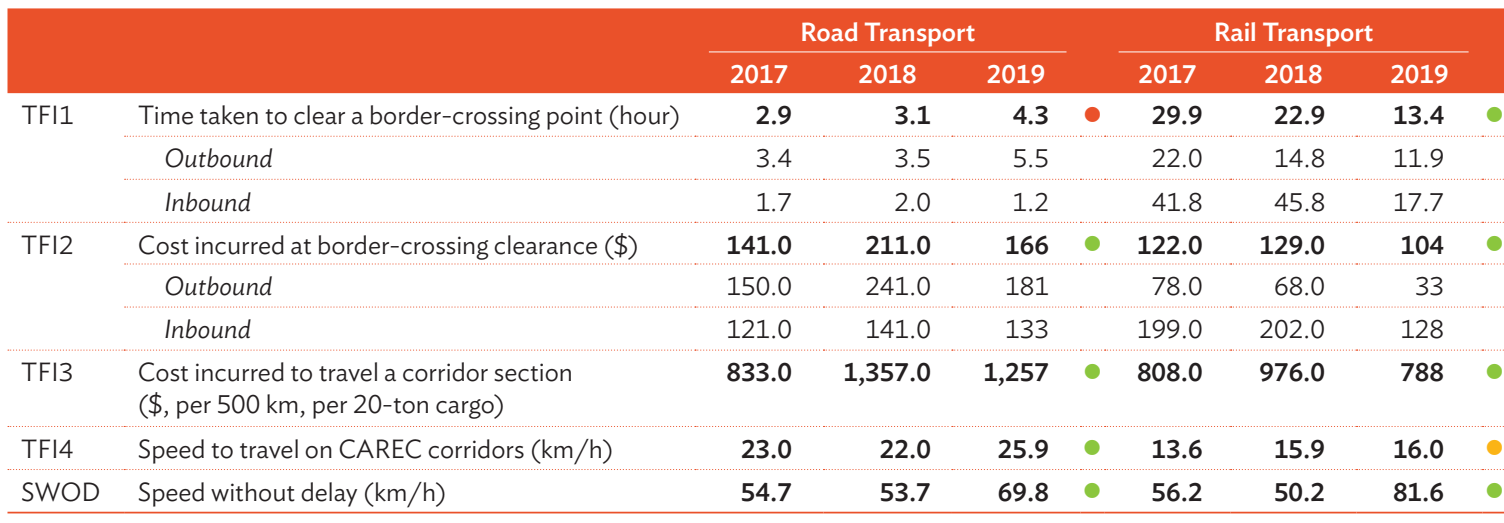

Legend: - Improved by at least 3\% - Deteriorated by at least 3\% Insignificant change [-3\% to 3\%]

- = no data, $\mathrm{CAREC}=$ Central Asia Regional Economic Cooperation, $\mathrm{km}=$ kilometer, $\mathrm{km} / \mathrm{h}=$ kilometer per hour, SWOD $=$ speed without delay, $\mathrm{TFI}=$ trade facilitation indicator.

Source: Asian Development Bank.

33 The previous train speed was generally at $80 \mathrm{~km} / \mathrm{h}$. New wagons are now designed for an operating speed of $120 \mathrm{~km} / \mathrm{h}$. https://www.crrcgc.cc/en/g6637. aspx.

34 UIC (International Union of Railways) 2019 Network Length and Track Density statistics. 
Table 6.6: Border-Crossing Performance in the People's Republic of China

\begin{tabular}{|c|c|c|c|c|c|c|c|c|}
\hline \multirow[b]{2}{*}{ BCP } & \multirow[b]{2}{*}{ Corridor } & \multirow{2}{*}{$\begin{array}{l}\text { Direction } \\
\text { of Trade }\end{array}$} & \multicolumn{3}{|c|}{$\begin{array}{l}\text { Duration } \\
\text { (hours) }\end{array}$} & \multicolumn{3}{|c|}{$\begin{array}{l}\text { Cost } \\
(\$)\end{array}$} \\
\hline & & & 2017 & 2018 & 2019 & 2017 & 2018 & 2019 \\
\hline \multicolumn{9}{|l|}{ Road Transport } \\
\hline \multirow[t]{2}{*}{ Takeshikent } & \multirow[t]{2}{*}{4} & Outbound & 7.1 & 6.6 & 6.3 & 228 & 256 & 309 \\
\hline & & Inbound & 6.3 & 4.5 & 4.4 & 331 & 298 & 246 \\
\hline Erenhot & 4 & Outbound & 3.2 & 3.0 & 6.7 & 150 & 164 & 144 \\
\hline \multirow[t]{2}{*}{ Horgos } & \multirow[t]{2}{*}{1} & Outbound & 8.8 & 10.2 & 11.0 & 595 & 588 & 450 \\
\hline & & Inbound & - & 20.4 & 15.7 & - & 113 & 80 \\
\hline \multirow[t]{2}{*}{ Torugart } & \multirow[t]{2}{*}{1} & Outbound & 1.9 & 1.8 & 1.6 & 4 & - & - \\
\hline & & Inbound & 2.2 & 0.1 & - & 8 & - & - \\
\hline \multirow[t]{2}{*}{ Irkeshtan } & \multirow[t]{2}{*}{2,5} & Outbound & 1.7 & 0.3 & 0.2 & - & - & - \\
\hline & & Inbound & - & - & 1.6 & - & - & 4 \\
\hline Karasu & 0 & Outbound & - & 4.2 & 4.1 & - & 380 & 207 \\
\hline Zuun Khatavch & 4 & Outbound & 1.9 & 1.3 & 1.3 & 15 & 16 & 16 \\
\hline Khunjerab & 5 & Outbound & 0.3 & 1.9 & 1.7 & - & - & - \\
\hline \multicolumn{9}{|l|}{ Rail Transport } \\
\hline Alashankou & 1,2 & Outbound & 21.3 & 21.9 & 17.3 & 71 & 49 & 2 \\
\hline \multirow[t]{2}{*}{ Erenhot } & \multirow[t]{2}{*}{4} & Outbound & 15.5 & 11.9 & 11.2 & 113 & 113 & 16 \\
\hline & & Inbound & 40.8 & 55.7 & 9.2 & 209 & 227 & 69 \\
\hline Horgos & 1 & Outbound & 34.0 & 10.9 & 7.6 & 82 & 61 & 14 \\
\hline
\end{tabular}

- = no data, $B C P=$ border-crossing point.

Source: Asian Development Bank.

The Manzhouli-Zabaykalsk BCP on the border with the Russian Federation also indirectly serves some CAREC countries.

The central government has set ambitious targets for rail freight growth, particularly in using containers for cargo transport: for example, for the first 11 months of 2019, the PRC's rail freight traffic grew by $6.7 \%$ year-on-year, yet its container traffic is growing faster still. 35 During the period 2016-2019, the annual growth rate for container traffic exceeded $20 \%$ each year, comprising $11 \%$ of the PRC's total freight volume in 2019.

A growing concern for policy makers is that heavy subsidies from local governments have supported the container block train growth and, consequently, distorted the market: for instance, some cities ship empty containers or containers loaded with zero-value cargo to make up the 41 containers needed to qualify for block train subsidy. Others are diverting seaborne shipments to exploit the heavy rail subsidies. Aware of the misuse of subsidies, the Ministry of Finance now emphasizes sustainable growth in rail transport and has mandated all block train subsidies must end by 2022.

As land straddling the border is quite limited, the PRC is developing interior-bonded logistics centers to relieve $\mathrm{BCP}$ congestion and improve $\mathrm{BCP}$ handling capacity, such as the construction of a type- $\mathrm{B}$ bonded logistics center for bonded storage in Bayannur. ${ }^{36}$ This center will provide bonded warehousing for bulk mineral products from Mongolia, store imported agricultural products from the Russian Federation and Kazakhstan, and also facilitate the export of fruits and vegetables to Mongolia and the Russian Federation.

5 "Outline of Steps to Build a Strong Transportation Country" issued by the PRC State Council in September 2019.

36 "Layout and Construction Planning of National Logistics Hubs" jointly issued by the PRC National Reform and Development Commission and Ministry Transport on 25 December 2018. 


\section{Recommendations}

(i) Explore means to reduce road freight costs on the Urumqi-Almaty route. This is a highdensity road transport route, with Almaty acting as a distribution center to transship goods to other parts of Kazakhstan or the Russian Federation. CPMM data showed that the road freight rate within Kazakhstan is much higher than that in the Xinjiang Uygur Autonomous Region. Policies to facilitate operation of PRC trucks in neighboring countries would help bring the freight rates down.

(ii) Consider using Urumqi as a consolidation center for trains to Europe and Central Asia. Using Urumqi as a consolidation hub for second-tier eastern PRC cities that lack sufficient volume to make up regularly scheduled block trains with enough frequency, would ensure fuller trains and more frequent service to international destinations.

\section{Georgia}

\section{Key Findings}

(i) The CPMM reported good results for Georgia in 2019, with three of the four TFIs improving. Average border-crossing time decreased from 13.4 hours in 2018 to 10.6 hours in 2019, with shorter border-crossing times at Tsiteli Khidi for both inbound and outbound directions contributing to this improvement, together with trucks spending less time waiting in line to cross the border to Azerbaijan. Cost to travel a corridor section saw significant reduction from $\$ 244$ in 2018 to $\$ 185$ in 2019. Both SWOD and SWD increased: SWOD rose from $49.3 \mathrm{~km} / \mathrm{h}$ in 2018 to $56.8 \mathrm{~km} / \mathrm{h}$ in 2019, while SWD increased from $18.8 \mathrm{~km} / \mathrm{h}$ to $21.5 \mathrm{~km} / \mathrm{h}$.

(ii) The Tsiteli Khidi BCP at the border with Azerbaijan is a gateway for transit movements to and from Central Asia. While outbound shipments averaged 13.4 hours and inbound shipments averaged 2.1 hours, border security and customs controls at Tsiteli Khidi took only 5 minutes. The long time spent at the border was due to trucks waiting to cross to Krasnyi Most BCP in Azerbaijan.

Table 6.7: Trade Facilitation Indicators for Georgia

\begin{tabular}{|c|c|c|c|c|c|c|c|c|c|}
\hline & & \multicolumn{3}{|c|}{ Road Transport } & & \multicolumn{4}{|c|}{ Rail Transport } \\
\hline & & 2017 & 2018 & 2019 & & 2017 & 2018 & 2019 & \\
\hline \multirow[t]{3}{*}{ TFI1 } & Time taken to clear a border-crossing point (hour) & - & 14.3 & 11.0 & $\bullet$ & - & - & - & - \\
\hline & Outbound & - & 17.9 & 13.4 & & - & - & - & \\
\hline & Inbound & - & 9.0 & 2.0 & & - & - & - & \\
\hline \multirow[t]{3}{*}{ TFI2 } & Cost incurred at border-crossing clearance $(\$)$ & - & 66.0 & 74 & $\bullet$ & - & - & - & - \\
\hline & Outbound & - & 67.0 & 73 & & - & - & - & \\
\hline & Inbound & - & 64.0 & 80 & & - & - & - & \\
\hline TFI3 & $\begin{array}{l}\text { Cost incurred to travel a corridor section } \\
(\$, \text { per } 500 \mathrm{~km} \text {, per } 20 \text {-ton cargo) }\end{array}$ & - & 244.0 & 193 & $\bullet$ & - & - & - & - \\
\hline TFI4 & Speed to travel on CAREC corridors $(\mathrm{km} / \mathrm{h})$ & - & 18.8 & 21.4 & - & - & - & - & - \\
\hline SWOD & Speed without delay $(\mathrm{km} / \mathrm{h})$ & - & 49.3 & 58.4 & $\bullet$ & - & - & - & - \\
\hline
\end{tabular}

Legend: - Improved by at least 3\% - Deteriorated by at least 3\%

- = no data, $\mathrm{CAREC}=$ Central Asia Regional Economic Cooperation, $\mathrm{km}=$ kilometer, $\mathrm{km} / \mathrm{h}=$ kilometer per hour, $\mathrm{SWOD}=$ speed without delay, $\mathrm{TFI}=$ trade facilitation indicator.

Source: Asian Development Bank. 
Table 6.8: Border-Crossing Performance in Georgia

\begin{tabular}{|c|c|c|c|c|c|c|c|c|}
\hline \multirow[b]{2}{*}{$\mathrm{BCP}$} & \multirow[b]{2}{*}{ Corridor } & \multirow{2}{*}{$\begin{array}{l}\text { Direction } \\
\text { of Trade }\end{array}$} & \multicolumn{3}{|c|}{$\begin{array}{l}\text { Duration } \\
\text { (hours) }\end{array}$} & \multicolumn{3}{|c|}{$\begin{array}{l}\text { Cost } \\
(\$)\end{array}$} \\
\hline & & & 2017 & 2018 & 2019 & 2017 & 2018 & 2019 \\
\hline \multicolumn{9}{|c|}{ Road Transport } \\
\hline \multirow[t]{2}{*}{ Takeshikent } & 2 & Outbound & - & 17.9 & 13.4 & - & 67 & 52 \\
\hline & & Inbound & - & 1.2 & 2.1 & - & - & - \\
\hline \multirow[t]{2}{*}{ Sarpi } & 2 & Outbound & - & - & - & - & - & - \\
\hline & & Inbound & - & 4.3 & 6.2 & - & - & 9 \\
\hline
\end{tabular}

- = no data, $B C P=$ border-crossing point.

Source: Asian Development Bank.

\section{Trends and Developments}

Georgia is already a leader in trade facilitation policy reform and procedure simplification, and made further headway in 2019: it adopted international standards and approved transportation technical regulations to deepen trade integration with the European Union (EU); developed the "Roadmap for Georgia's EU Integration," prepared for implementation of the EU New Computerized Transit System; approved Resolution 89 on "Role of Carriage of Dangerous Goods"; and Georgia Customs began classifying commodity codes under the European Agreement concerning the International Carriage of Dangerous Goods by Road. ${ }^{37}$ These achievements will improve Georgia's transit appeal to CAREC member countries interested in accessing European Union (EU) markets.

Georgian carriers have long transported shipments under TIR. A trilateral agreement was signed in 2019 between International Road Transport Union, Georgian Revenue Service, and Georgia International Road Carriers Association to roll out Electronic TIR (or eTIR). Using information technology to exchange information, shipment data can be easily shared between Georgia and Azerbaijan, Kazakhstan, and Ukraine. Work continued on the CAREC Advanced Transit System (CATS) among Azerbaijan, Georgia, and Kazakhstan, which will allow carriers and shippers to benefit from a single and standardized electronic transit system. The Ministry of Finance of Georgia is also negotiating with the State Customs Service of the Kyrgyz Republic to implement data exchange on cargo shipments.

Two BCPs stand out as important nodes for regional trade in CPMM. The first is Sarpi, the BCP at the Georgia-Turkey border. There are several shipments from Turkey to Georgia to Central Asia sent on trucks. Sarpi is the gateway for such traffic. The second is Tsiteli Khidi, located at the Georgia-Azerbaijan border. Goods from Poti or Batumi seaports, as well as from Turkey, will pass through this node and enter Central Asia via Baku seaport in Azerbaijan. Georgia and Turkey have signed an agreement to adopt joint customs controls at Georgia-Turkey BCPs including Sarpi. ${ }^{38}$ Negotiations are ongoing to determine the protocols in data sharing, pre-arrival declaration of cargo manifest details, and examination rates for $\mathrm{X}$-ray on cargo vehicles. At Tsiteli Khidi, the EU financed the modernization of the infrastructure and the equipment of this BCP and it is now compliant to EU's construction standards. ${ }^{39}$

37 According to the World Bank Doing Business report, Georgia is ranked in seventh place overall and made the greatest progress toward the frontier in regulatory practice in trading across borders since 2005. See https:/www.doingbusiness.org/content/dam/doingBusiness/media/Annual-Reports/ English/DB13-Chapters/Trading-across-borders.pdf and https://www.doingbusiness.org/content/dam/doingBusiness/country/g/georgia/ GEO.pdf.

38 "Regulatory and Procedural Barriers to Trade in Georgia." UNECE. 2018. p. 56. https://www.unece.org/fileadmin/DAM/trade/Publications/ECE TRADE_443E_Georgia.pdf.

39 EU Neighbours. Eastern Partnership Integrated Border Management Flagship Initiative: Support to the development of Red Bridge Border crossing point between Georgia and Azerbaijan. https:/www.euneighbours.eu/en/east/stay-informed/projects/eastern-partnership-integrated-bordermanagement-flagship-initiative-1. 


\section{Recommendations}

(i) Continue prioritizing improvements at Tsiteli Khidi-Krasnyi Most (GEO-AZE) BCP. This important BCP was upgraded in 2019, including the piloting of electronic data interchange. With individual BCP activities now being completed rapidly and efficiently, establishment of joint customs controls would help reduce the remaining lengthy time spent waiting at the neutral zone.

(ii) Explore transit corridor through Turkmenistan as alternative route to Central Asia. Georgian operators carry shipments of building materials and heavy machineries to support infrastructure projects in Tajikistan, yet tend to favor a longer route through Kazakhstan rather than travel the shorter distance through Turkmenistan due to trade facilitation barriers and difficulties in obtaining visas for the latter.

(iii) Consider development of agreements with Central Asia to improve efficiency of transport. In 2019, Georgia continued developing transit agreements with Azerbaijan and Kazakhstan. Additional bilateral or multilateral agreements with other Central Asian republics could reduce the costs of shipments: for instance, a shipment carried by a Georgian operator is subject to $\$ 200-\$ 300$ when it enters Tajikistan at Tursunzade or Fotehobod BCPs, whereas the same shipment coming from the Kyrgyz Republic or Uzbekistan costs only $\$ 30$ at the same BCPs. Furthermore, payments by Georgian operators include substantial tea money. Concluding necessary agreements and clarifying fees could improve the business practices of transport business to Central Asia.

(iv) Develop rail transport to increase regional connectivity. Rail transport freight tonnage in Georgia was used in the past mainly to transport oil, but experienced significant decline since 2014. ${ }^{40}$ However, rising popularity of the Trans-Caspian International Transport Route represents new opportunities to serve transit business, in particular, shipments to and from Turkey and southern Europe (especially Black Sea and Mediterranean littoral states).

\section{Kazakhstan}

\section{Key Findings}

(i) In 2019, CPMM data reported an increase in average border-crossing time and cost. Total transport costs fell while speed showed a mixed performance during 2018-2019.

(ii) Road transport showed an increase in average border-crossing time, with Karasu BCP on the border with the Kyrgyz Republic ranked the most time-consuming for incoming traffic with an average duration of 34.4 hours, compared to 0.3 hours in 2018. This was due to Kazakhstan border guards adopting a strict inspection approach toward Kyrgyz trucks carrying PRC merchandise. Konysbaeva and Tazhen BCPs, at the border with Uzbekistan, saw little change since 2018; and Khorgos BCP clocked an average of 5.7 hours, with time spent waiting as the principal cause.

(iii) Average border-crossing cost rose from $\$ 96$ in 2018 to $\$ 115$ in 2019, reflecting the jump in fees at Karasu BCP, from $\$ 16$ in 2018 to $\$ 101$ in 2019 . This was mostly due to unofficial payments to secure early release of the shipment.

(iv) Total transport cost decreased from $\$ 791$ in 2018 to $\$ 715$ in 2019, despite the increase of bordercrossing fees, implying that road freight costs could have declined.

(v) SWOD and SWD remained stable during 2018-2019. SWOD dropped from $56.3 \mathrm{~km} / \mathrm{h}$ to $53.2 \mathrm{~km} / \mathrm{h}$, while SWD showed a slight change from $30.5 \mathrm{~km} / \mathrm{h}$ to $30.7 \mathrm{~km} / \mathrm{h}$. 
(vi) In 2019, rail transport showed stable year-on-year border-crossing time and cost. Of note, total transport cost dropped from $\$ 768$ in 2018 to $\$ 687$ in 2019. However, speed showed a divergent pattern: although SWOD increased from $56.4 \mathrm{~km} / \mathrm{h}$ to $67.8 \mathrm{~km} / \mathrm{h}$, SWD dropped from $19.9 \mathrm{~km} / \mathrm{h}$ to $18.1 \mathrm{~km} / \mathrm{h}$, implying significant impediments at rail BCPs.

(vii) Although Dostyk improved from an average 61 hours in 2018 to 48.2 hours in 2019, it was still ranked the most time-consuming border for rail transport. Altynkol average time rose from 39.6 hours in 2018 to 44.7 hours in 2019. Key causes included a shortage of wagons, marshaling time, and materials transfer.

(viii) Average border-crossing cost at Dostyk was $\$ 534$ and at Altynkol $\$ 252$, relatively unchanged from 2018 figures ( $\$ 549$ at Dostyk and $\$ 251$ at Altynkol).

Table 6.9: Trade Facilitation Indicators for Kazakhstan

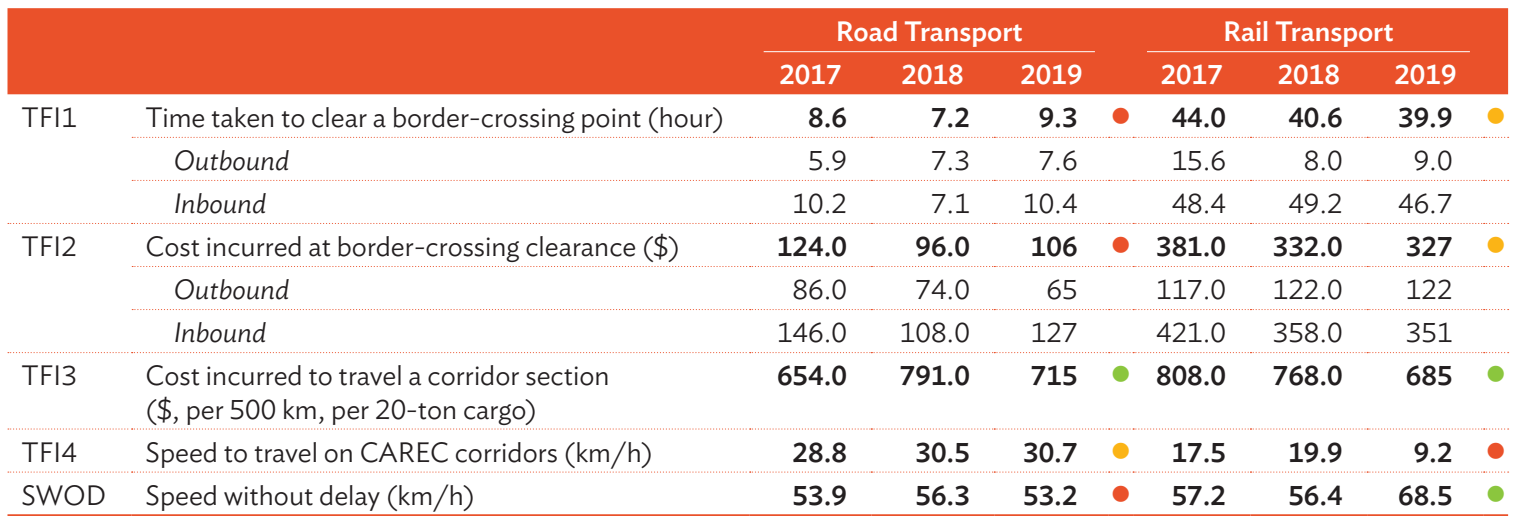

Legend: - Improved by at least 3\% - Deteriorated by at least 3\% Insignificant change [-3\% to 3\%]

CAREC $=$ Central Asia Regional Economic Cooperation, $\mathrm{km}=$ kilometer, $\mathrm{km} / \mathrm{h}=$ kilometer per hour, SWOD $=$ speed without delay, $\mathrm{TFI}=$ trade facilitation indicator.

Source: Asian Development Bank.

Table 6.10: Border-Crossing Performance in Kazakhstan

\begin{tabular}{|c|c|c|c|c|c|c|c|c|}
\hline \multirow[b]{2}{*}{$\mathrm{BCP}$} & \multirow[b]{2}{*}{ Corridor } & \multirow{2}{*}{$\begin{array}{l}\text { Direction } \\
\text { of Trade }\end{array}$} & \multicolumn{3}{|c|}{$\begin{array}{l}\text { Duration } \\
\text { (hours) }\end{array}$} & \multicolumn{3}{|c|}{$\begin{array}{l}\text { Cost } \\
(\$)\end{array}$} \\
\hline & & & 2017 & 2018 & 2019 & 2017 & 2018 & 2019 \\
\hline \multicolumn{9}{|c|}{ Road Transport } \\
\hline \multirow[t]{2}{*}{ Aul } & \multirow[t]{2}{*}{3} & Outbound & 25.2 & 0.2 & 0.4 & 21 & - & 14 \\
\hline & & Inbound & - & 0.2 & 0.4 & - & - & 12 \\
\hline \multirow[t]{2}{*}{ Kairak } & \multirow[t]{2}{*}{1} & Outbound & - & 0.2 & 5.7 & - & 2 & 8 \\
\hline & & Inbound & 0.5 & 0.3 & 2.0 & 7 & 16 & 25 \\
\hline \multirow[t]{2}{*}{ Zhaisan } & \multirow[t]{2}{*}{1,6} & Outbound & - & 0.2 & 1.4 & - & 9 & 14 \\
\hline & & Inbound & - & 0.2 & 0.6 & - & 8 & 10 \\
\hline \multirow[t]{2}{*}{ Tazhen } & \multirow[t]{2}{*}{2,6} & Outbound & 7.5 & 12.6 & 11.8 & 130 & 104 & 100 \\
\hline & & Inbound & 8.0 & 11.4 & 8.7 & 133 & 116 & 107 \\
\hline \multirow[t]{2}{*}{ Kurmangazy } & \multirow[t]{2}{*}{6} & Outbound & 3.7 & 2.2 & 2.5 & 41 & 11 & 10 \\
\hline & & Inbound & 2.7 & 2.2 & 2.1 & 30 & 10 & 9 \\
\hline \multirow[t]{2}{*}{ Konysbayeva } & \multirow[t]{2}{*}{3,6} & Outbound & - & - & 4.4 & - & - & 45 \\
\hline & & Inbound & 8.0 & 12.0 & 11.6 & 163 & 130 & 128 \\
\hline \multirow[t]{2}{*}{ Aisha Bibi } & \multirow[t]{2}{*}{1,3} & Outbound & - & - & - & - & - & - \\
\hline & & Inbound & - & 0.7 & 9.5 & - & 12 & 15 \\
\hline
\end{tabular}


Table 6.10 continued

\begin{tabular}{|c|c|c|c|c|c|c|c|c|}
\hline \multirow[b]{2}{*}{$\mathrm{BCP}$} & \multirow[b]{2}{*}{ Corridor } & \multirow{2}{*}{$\begin{array}{l}\text { Direction } \\
\text { of Trade }\end{array}$} & \multicolumn{3}{|c|}{$\begin{array}{l}\text { Duration } \\
\text { (hours) }\end{array}$} & \multicolumn{3}{|c|}{$\begin{array}{l}\text { Cost } \\
(\$)\end{array}$} \\
\hline & & & 2017 & 2018 & 2019 & 2017 & 2018 & 2019 \\
\hline \multirow[t]{2}{*}{ Taskala } & 1,6 & Outbound & 3.4 & 1.9 & 1.9 & 35 & 11 & 10 \\
\hline & & Inbound & - & - & 1.5 & - & - & 12 \\
\hline \multirow[t]{2}{*}{ Jana Jol } & 1,6 & Outbound & - & - & - & - & - & - \\
\hline & & Inbound & 0.6 & - & - & 7 & - & - \\
\hline \multirow[t]{2}{*}{ Pogodaevo } & 0 & Outbound & - & 0.1 & - & - & - & - \\
\hline & & Inbound & - & 1.8 & 1.9 & - & 10 & 10 \\
\hline \multirow[t]{2}{*}{ Aktau } & 2 & Outbound & - & 1.6 & 0.6 & - & 108 & 57 \\
\hline & & Inbound & - & 3.0 & 1.0 & - & 132 & 130 \\
\hline \multirow[t]{2}{*}{ Khorgos } & 1 & Outbound & - & 4.5 & 1.1 & - & 220 & - \\
\hline & & Inbound & 4.1 & 6.8 & 5.7 & 329 & 341 & 339 \\
\hline \multirow[t]{2}{*}{ Merke } & 1,3 & Outbound & 3.5 & 1.5 & 2.7 & 23 & 10 & 12 \\
\hline & & Inbound & - & 0.3 & 0.1 & - & 16 & 6 \\
\hline \multirow[t]{2}{*}{ Kordai } & 1 & Outbound & - & - & - & - & - & - \\
\hline & & Inbound & - & 0.2 & 0.2 & - & 11 & - \\
\hline \multirow[t]{2}{*}{ Karasu } & 1 & Outbound & 0.3 & 0.2 & 1.7 & 17 & 7 & 15 \\
\hline & & Inbound & 0.5 & 0.3 & 34.4 & 10 & 16 & 101 \\
\hline \multirow[t]{2}{*}{ Kuryk } & 2 & Outbound & - & - & 44.7 & - & - & 204 \\
\hline & & Inbound & - & - & 14.8 & - & - & 321 \\
\hline \multicolumn{9}{|c|}{ Rail Transport } \\
\hline Saryagash & 3,6 & Outbound & - & 9.1 & 9.6 & - & 122 & 122 \\
\hline \multirow[t]{2}{*}{ Dostyk } & 1,2 & Outbound & - & - & - & - & - & - \\
\hline & & Inbound & 50.6 & 61.0 & 48.2 & 522 & 549 & 534 \\
\hline Merke & 1,3 & Outbound & 2.1 & 1.6 & 2.5 & - & - & - \\
\hline \multirow[t]{2}{*}{ Altynkol } & 1 & Outbound & - & - & - & - & - & - \\
\hline & & Inbound & 56.0 & 39.6 & 44.7 & 613 & 251 & 252 \\
\hline Saryagash & 3,6 & Inbound & - & 9.1 & 9.6 & - & 122 & 122 \\
\hline
\end{tabular}

- = no data, $B C P=$ border-crossing point.

Source: Asian Development Bank.

\section{Trends and Developments}

No significant change was seen at the majority of Kazakh BCPs in 2019, apart from at Karasu BCP. As noted above, in March 2019, Kazakhstan Revenue Committee at Karasu began requiring full physical examination of Kyrgyz trucks carrying PRC merchandise into Kazakhstan as an anti-smuggling measure. Time-consuming unloading, checking, and tallying against the Convention of Contract for the International Carriage of Goods by Road (CMR) Waybill led to very long delays - and nonadmitted trucks-at both Karasu BCP and the adjacent Ak-Tilek BCP. The CPMM also registered many complaints of unofficial payments during this time, ranging from $\$ 500$ to $\$ 1,000$ per truck. A negotiated agreement halted this approach and on 8 April 2019 border procedures returned to normal. CPMM data for 2019 clearly reflect the increased time and cost for trade during the 6-week period and the impact on annual averages.

The Ministry of Industry and Infrastructure Development and the Ministry of Economy worked actively with the private sector in 2019 to resolve ongoing issues and impediments in the rail sector, including the introduction of amendments to the Rules of Transportation of Shipments by Railways, approved under Order Number 612 on 2 August 2019.41 
Trains crossing Dostyk and Altynkol took comparatively longer than other BCPs due to issues of availability of wagons. Following privatization of Kazakhstan Temir Zholy (KTZ), the national rail operator, there was no incentive for KTZ to deploy resources as needed because the wagons became the property of the controlling external private companies. Rules for use of privately owned wagons have not yet been established. Further delays are caused when containers or wagons are confiscated by customs along with the relevant shipment.

In July 2019, China Railways increased the maximum length of wagons in a single train to 70 , which improves the capacity of a single train-trip, but risks stations not being able to handle such long trains because of insufficient shunting locomotives and tracks: this is the case at Altynkol BCP, which will need to upgrade its capacity (footnote 41).

CPMM samples included Kuryk seaport in 2019, a new terminal at Aktau that services Trans-Caspian shipment. Waiting time was estimated at 1-2 days due to the waiting time for vessels.

\section{Recommendations}

(i) Prioritize completion of updating and revision of the Law for Transportation of Shipments by Railways approved under Order 612. Various amendment proposals were submitted in 2019 to update national law to reflect more modern market-driven practices, but the Railway Transport Subcommittee of the Logistics and Transport Operations Committee should accelerate the process to complete the amendments.

(ii) Draft a standard agreement format between railway carriers and private wagon owners. This could serve as a model template and permit railway stations to deploy privately owned wagons for loading goods coming from the PRC to other destinations. This could be added as an amendment to the new railway law.

(iii) Streamline and simplify contractual processes between KTZ and other market participants. Following privatization of $\mathrm{KTZ}$, there are different market participants in rail transport that must work together. However, the contracting process is cumbersome and time-consuming: KTZ first requires a set of documents from the market participants, and then the same documents are required from subsidiaries such as KTZ Express for services such as forwarding, container leasing, and pickup and delivery of wagons. KTZ should create a central customs database to record all details so that the administrative effort to conclude a new agreement or extend an existing one is simpler.

(iv) Upgrade Altynkol to receive "long trains" from the PRC. This would require the increase of shunting locomotives and new and longer rail tracks for more efficient operation.

(v) Clarify the rules of payment for detention charges. When customs detain shipments at Dostyk or Altynkol BCPs for further investigation and identify contravention of rules, the railway authority will impose detention charges on the freight forwarders, who might or might not succeed in recovering the fees from the consignee or consignor. This issue could be included as an amendment to the updated railway law.

(vi) Increase the efficiency of BCPs (e.g., Karasu). The problem of long border-crossing times at Karasu BCP appeared unannounced and disrupted cross-border traffic, especially given that physical examination is a time-consuming process. As Karasu is a high-traffic BCP, a capacity study should be conducted to identify potential improvements, including for example installation of truck and pallet scanners to make inspections more efficient. 


\section{Kyrgyz Republic}

\section{Key Findings}

(i) Average outbound traffic border clearance time and cost improved in 2019: from 1.1 hours (2018) to 0.9 hours (2019) and from $\$ 23$ (2018) to $\$ 21$ (2019).

(ii) However, these gains were offset, by new procedures instituted by the Government of Kazakhstan whereby Kyrgyz trucks crossing from the Kyrgyz Republic into Kazakhstan in March-April 2019 were subjected to unannounced, additional, and time-consuming physical inspection by the Kazakhstan Revenue Committee after entering Kazakh territory. ${ }^{42}$ Such inspections led to high variability in the time and cost of shipping cargo to or through Kazakhstan.

(iii) At Kazakh BCPs with the PRC, Tajikistan, and Uzbekistan, average border crossing remained similar to 2018 levels.

(iv) The cost to travel a corridor section fell slightly from $\$ 1,219$ (2018) to $\$ 1,122$ (2019).

(v) Speed to travel a corridor section increased from $29.8 \mathrm{~km} / \mathrm{h}$ in 2018 to $30.8 \mathrm{~km} / \mathrm{h}$ in 2019, even though there was a small drop in SWOD.

\section{Trends and Developments}

Accession to the Eurasian Economic Union in August 2015 brought significant improvement in bordercrossing procedures and time at the Kazakhstan-Kyrgyz Republic borders. CPMM data and samples for 2019 CPMM indicators show a modest continuation of the positive overall trend, with significant improvement at its major BCP Ak-Tilek.

However, during March-April 2019, the Kazakhstan Revenue Committee initiated random checks at KGZ-KAZ BCPs targeting Kyrgyz trucks carrying goods from the PRC. These very thorough checks encompassed detailed verification of documents and cargo, frequently leading to long lines and waiting times. Kyrgyz Freight Operator Association reported the extortion of unofficial payments connected to these checks-a matter taken up and not yet resolved by the two governments.

\section{Recommendations}

(i) Reopen the Karamyk border route to third-country transit traffic. Despite the signing of a cross-border transit agreement between the Kyrgyz Republic and Tajikistan, this route was closed to third-country traffic, and transit traffic between Tajikistan and the PRC must use the IsfaraBatken route, which is much longer and more costly. In the interests of regional cooperation, the Government of the Kyrgyz Republic should consider reopening the Karamyk route to thirdcountry transit traffic. For a brief period in 2019, the Dushanbe-Karamyk-Irkeshtam route was opened to traffic between Tajikistan and the PRC.

(ii) Improve customer service for cargo movement on railways. Unlike the efficient global positioning system used for road transport in the Kyrgyz Republic, the Kyrgyz Railway suffers from poor cargo-tracking capacity, making it difficult for Kyrgyz forwarders to provide rail transit data for the CPMM. As part of the effort to commercialize and reform the railway network, the government should improve customer service, such as implementing cargo-tracking systems.

42 CPMM consultant survey and various news agencies, including the news web site https://24.kg/english/in. 
Table 6.11: Trade Facilitation Indicators for the Kyrgyz Republic

\begin{tabular}{|c|c|c|c|c|c|c|c|c|c|}
\hline & \multicolumn{3}{|c|}{ Road Transport } & & \multicolumn{4}{|c|}{ Rail Transport } \\
\hline & & 2017 & 2018 & 2019 & & 2017 & 2018 & 2019 & \\
\hline \multirow[t]{3}{*}{ TFI1 } & Time taken to clear a border-crossing point (hour) & 3.5 & 1.6 & 1.6 & - & - & 1.2 & 1.2 & 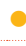 \\
\hline & Outbound & 2.9 & 1.1 & 0.9 & & - & - & - & \\
\hline & Inbound & 4.0 & 2.0 & 2.0 & & - & 1.2 & 1.2 & \\
\hline \multirow[t]{3}{*}{ TFI2 } & Cost incurred at border-crossing clearance $(\$)$ & 121 & 24 & 23 & $\bullet$ & - & - & - & - \\
\hline & Outbound & 36 & 23 & 21 & & - & - & - & \\
\hline & Inbound & 175 & 25 & 25 & & - & - & - & \\
\hline TFI3 & $\begin{array}{l}\text { Cost incurred to travel a corridor section } \\
(\$, \text { per } 500 \mathrm{~km} \text {, per } 20 \text {-ton cargo) }\end{array}$ & 781 & 1,219 & 1,122 & $\bullet$ & 456 & 434 & 338 & • \\
\hline TFI4 & Speed to travel on CAREC corridors $(\mathrm{km} / \mathrm{h})$ & 28.1 & 29.8 & 30.8 & - & 35.9 & 21.6 & 23.5 & - \\
\hline SWOD & Speed without delay $(\mathrm{km} / \mathrm{h})$ & 49.1 & 50.9 & 50.6 & - & 50.7 & 28.7 & 33.2 & - \\
\hline
\end{tabular}

Legend: - Improved by at least 3\% - Deteriorated by at least 3\% Insignificant change [-3\% to 3\%]

- = no data, $\mathrm{CAREC}=$ Central Asia Regional Economic Cooperation, $\mathrm{km}=$ kilometer, $\mathrm{km} / \mathrm{h}=$ kilometer per hour, $\mathrm{SWOD}=$ speed without delay, $\mathrm{FI}=$ trade facilitation indicator.

Source: Asian Development Bank.

Table 6.12: Border-Crossing Performance in the Kyrgyz Republic

\begin{tabular}{|c|c|c|c|c|c|c|c|c|}
\hline \multirow[b]{2}{*}{ BCP } & \multirow[b]{2}{*}{ Corridor } & \multirow{2}{*}{$\begin{array}{l}\text { Direction } \\
\text { of Trade }\end{array}$} & \multicolumn{3}{|c|}{$\begin{array}{c}\text { Duration } \\
\text { (hours) }\end{array}$} & \multicolumn{3}{|c|}{$\begin{array}{c}\text { Cost } \\
(\$)\end{array}$} \\
\hline & & & 2017 & 2018 & 2019 & 2017 & 2018 & 2018 \\
\hline \multicolumn{9}{|c|}{ Road Transport } \\
\hline \multirow[t]{2}{*}{ Dostuk } & 2 & Outbound & - & 0.9 & 0.6 & - & 21 & 16 \\
\hline & & Inbound & 1.2 & 0.6 & 1.0 & 30 & 17 & 22 \\
\hline \multirow[t]{2}{*}{ Chaldovar } & 1,3 & Outbound & - & 0.2 & 0.2 & - & 7 & 9 \\
\hline & & Inbound & 3.8 & 1.2 & 1.7 & 23 & 8 & 8 \\
\hline \multirow[t]{2}{*}{ Karamyk } & $2,3,5$ & Outbound & 2.3 & 2.1 & 2.1 & 48 & 42 & 45 \\
\hline & & Inbound & 1.8 & 0.8 & 0.6 & 25 & 21 & 19 \\
\hline Ak Zhol & 1 & Outbound & - & 0.3 & 0.2 & - & 8 & 4 \\
\hline \multirow[t]{2}{*}{ Kensay } & 0 & Outbound & - & - & - & - & - & - \\
\hline & & Inbound & - & - & 1.4 & - & - & 18 \\
\hline \multirow[t]{2}{*}{ Kyzyl-Bel } & 0 & Outbound & 1.5 & 1.1 & 0.5 & 47 & 19 & 13 \\
\hline & & Inbound & - & 3.3 & 0.9 & - & 36 & 23 \\
\hline \multirow[t]{2}{*}{ Torugart } & 1 & Outbound & 0.7 & 1.9 & - & 22 & 33 & - \\
\hline & & Inbound & 2.1 & 2.3 & 2.2 & 37 & 32 & 28 \\
\hline \multirow[t]{2}{*}{ Irkeshtam } & 2,5 & Outbound & - & - & 1.2 & - & - & 43 \\
\hline & & Inbound & 2.4 & 0.9 & 0.8 & 980 & 24 & 15 \\
\hline \multirow[t]{2}{*}{ Chon Kapka } & 1,3 & Outbound & - & 0.3 & 0.3 & - & 10 & 6 \\
\hline & & Inbound & - & - & - & - & - & - \\
\hline \multirow[t]{2}{*}{ Ak-Tilek } & 1 & Outbound & 7.5 & 0.2 & 0.1 & 6 & 9 & 4 \\
\hline & & Inbound & 0.2 & 0.2 & 0.1 & 12 & 7 & 2 \\
\hline \multicolumn{9}{|c|}{ Rail Transport } \\
\hline \multirow[t]{2}{*}{ Chaldovar } & 1,3 & Outbound & - & - & - & - & - & - \\
\hline & & Inbound & - & 1.2 & 1.2 & - & - & - \\
\hline
\end{tabular}

- = no data, $\mathrm{BCP}=$ border-crossing point.

Source: Asian Development Bank. 


\section{Mongolia}

\section{Key Findings}

(i) In 2019, both road and rail transport reported mixed performance for Mongolia, displaying an increase in border-crossing time and cost compared to 2018, while total cost declined. Road transport suffered from lower speeds in 2019, while rail transport benefited from higher speeds.

(ii) For road transport in 2019, border-crossing time increased slightly from 3.5 hours to 3.7 hours year-on-year, due to border crossing at Zamiin-Uud for inbound cargoes, which experienced an increase from 4.0 hours to 4.5 hours during 2018-2019. Border security (1.2 hours) and customs controls (1.8 hours) were the main culprits of delay.

(iii) Average border-crossing costs crept up from $\$ 93$ to $\$ 97$ during 2018-2019 and were likewise due to the Zamiin-Uud BCP, where fees per truck averaged $\$ 133$, up from $\$ 121$ in 2018 -payments to border control and customs controls were key factors. However, total average cost decreased from $\$ 1,512$ to $\$ 1,373$ during $2018-2019$.

(iv) Speeds dropped in 2019, falling from $50.2 \mathrm{~km} / \mathrm{h}$ in 2018 to $40.8 \mathrm{~km} / \mathrm{h}$ for SWOD, and from $33.5 \mathrm{~km} / \mathrm{h}$ in 2018 to $26.2 \mathrm{~km} / \mathrm{h}$ for SWD.

(v) In 2019, rail transport saw a slight increase in average border-crossing time from 18.1 hours in 2018 to 19.0 hours, affected by changes at Zamiin-Uud BCP. While outbound cargo time was shorter, the average time to handle inbound cargoes grew from 22.9 hours in 2018 to 24.2 hours in 2019, largely due to the shortage of wagons, marshaling, and the time required to load goods.

(vi) Average border-crossing cost rose from $\$ 49$ to $\$ 52$ in 2019 . Commercial inspection and the change in gauge operation at Zamiin-Uud were the key cost drivers.

(vii) Total transport cost lowered from $\$ 1,030$ to $\$ 720$, showing that rail freight tariffs have reduced in 2019.

(viii) Both speeds reported higher levels in 2019 compared with 2018 data. SWOD increased from $14.1 \mathrm{~km} / \mathrm{h}$ to $19.1 \mathrm{~km} / \mathrm{h}$ and SWD increased from $20.9 \mathrm{~km} / \mathrm{h}$ to $24.1 \mathrm{~km} / \mathrm{h}$. This was achieved despite the longer average border-crossing time.

Table 6.13: Trade Facilitation Indicators for Mongolia

\begin{tabular}{|c|c|c|c|c|c|c|c|c|c|}
\hline & & \multicolumn{3}{|c|}{ Road Transport } & & \multicolumn{4}{|c|}{ Rail Transport } \\
\hline & & 2017 & 2018 & 2019 & & 2017 & 2018 & 2019 & \\
\hline \multirow[t]{3}{*}{ TFI1 } & Time taken to clear a border-crossing point (hour) & 3.2 & 3.5 & 3.7 & $\bullet$ & 13.3 & 18.1 & 19.0 & $\bullet$ \\
\hline & Outbound & 2.9 & 2.9 & 2.9 & & 7.6 & 11.7 & 8.7 & \\
\hline & Inbound & 3.2 & 3.5 & 3.7 & & 16.6 & 20.4 & 21.4 & \\
\hline \multirow[t]{3}{*}{ TFI2 } & Cost incurred at border-crossing clearance $(\$)$ & 93 & 93 & 97 & - & 48 & 49 & 52 & $\bullet$ \\
\hline & Outbound & 12 & 13 & 12 & & - & 27 & 11 & \\
\hline & Inbound & 104 & 104 & 109 & & 48 & 49 & 54 & \\
\hline TFI3 & $\begin{array}{l}\text { Cost incurred to travel a corridor section } \\
(\$, \text { per } 500 \mathrm{~km} \text {, per } 20 \text {-ton cargo) }\end{array}$ & 1,034 & 1,512 & 1,373 & - & 827 & 1,030 & 720 & $\bullet$ \\
\hline TFI4 & Speed to travel on CAREC corridors $(\mathrm{km} / \mathrm{h})$ & 28.5 & 33.5 & 26.2 & - & 13.6 & 14.1 & 19.1 & $\bullet$ \\
\hline SWOD & Speed without delay $(\mathrm{km} / \mathrm{h})$ & 46.5 & 50.2 & 40.8 & $\bullet$ & 22.7 & 20.9 & 24.1 & $\bullet$ \\
\hline
\end{tabular}


Table 6.14: Border-Crossing Performance in Mongolia

\begin{tabular}{|c|c|c|c|c|c|c|c|c|}
\hline \multirow[b]{2}{*}{ BCP } & \multirow[b]{2}{*}{ Corridor } & \multirow{2}{*}{$\begin{array}{l}\text { Direction } \\
\text { of Trade }\end{array}$} & \multicolumn{3}{|c|}{$\begin{array}{c}\text { Duration } \\
\text { (hours) }\end{array}$} & \multicolumn{3}{|c|}{$\begin{array}{l}\text { Cost } \\
(\$)\end{array}$} \\
\hline & & & 2017 & 2018 & 2019 & 2017 & 2018 & 2019 \\
\hline \multicolumn{9}{|c|}{ Road Transport } \\
\hline \multirow[t]{2}{*}{ Yarant } & \multirow[t]{2}{*}{4} & Outbound & 3.0 & 3.1 & 2.9 & 57 & 55 & 55 \\
\hline & & Inbound & 3.4 & 3.9 & 3.3 & 201 & 201 & 198 \\
\hline \multirow[t]{2}{*}{ Zamiin-Uud } & \multirow[t]{2}{*}{4} & Outbound & - & - & - & - & - & - \\
\hline & & Inbound & 3.5 & 4.0 & 4.5 & 123 & 121 & 133 \\
\hline \multirow[t]{2}{*}{ Altanbulag } & \multirow[t]{2}{*}{4} & Outbound & - & - & - & - & - & - \\
\hline & & Inbound & 2.5 & 2.2 & 1.9 & 5 & 10 & 12 \\
\hline \multirow[t]{2}{*}{ Bichigt } & \multirow[t]{2}{*}{4} & Outbound & - & - & - & - & - & - \\
\hline & & Inbound & 1.7 & 1.4 & 1.4 & 11 & 6 & 7 \\
\hline \multicolumn{9}{|c|}{ Rail Transport } \\
\hline \multirow[t]{2}{*}{ Sukhbaatar } & \multirow[t]{2}{*}{4} & Outbound & - & - & - & - & - & - \\
\hline & & Inbound & 11.1 & 7.4 & 6.2 & 11 & 8 & 5 \\
\hline \multirow[t]{2}{*}{ Zamiin-Uud } & \multirow[t]{2}{*}{4} & Outbound & 7.6 & 11.8 & 8.7 & - & 27 & 4 \\
\hline & & Inbound & 18.9 & 22.9 & 24.2 & 63 & 34 & 36 \\
\hline
\end{tabular}

- = no data, $B C P=$ border-crossing point.

Source: Asian Development Bank.

\section{Trends and Developments}

As a landlocked country, road and rail transport are essential in Mongolia. During the period 2015-2019, freight tonnage increased at a compound annual growth rate of 21\%. In 2019, the total freight tonnage carried showed a $60 \%-40 \%$ split between road and rail, but the freight turnover reported a $26 \%-73 \%$ split instead, highlighting the important role of rail transport in long distance transportation. Among the transport modes, however, road transport experienced the fastest annual growth rate (Figure 6.1).

To support long-term rail traffic growth, Mongolia has agreed with the Russian Federation to add a second track to its 900-km long Naushki (RUS)-Sukhbaatar (MON)-Zamiin-Uud (MON)-Erenhot (PRC) mainline, which constitutes the spine of the Trans-Mongolian rail network. The second track should more

Figure 6.1: Freight Carried by Different Transport Modes in Mongolia, 2015-2019

Carried Freight ('tons)

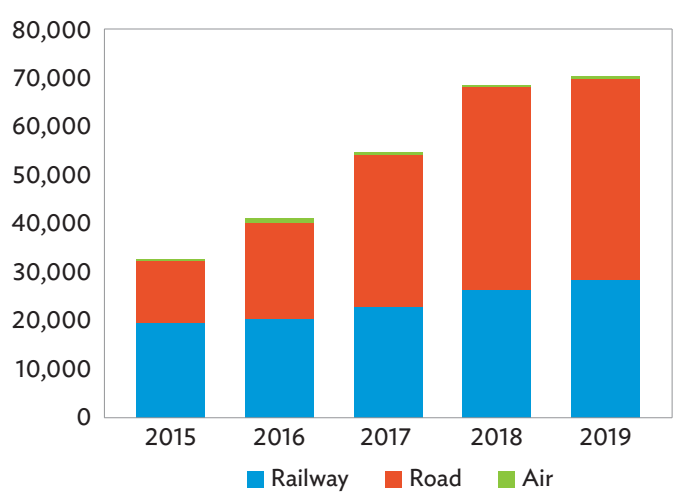

Freight Turnover (million tons kilometers)

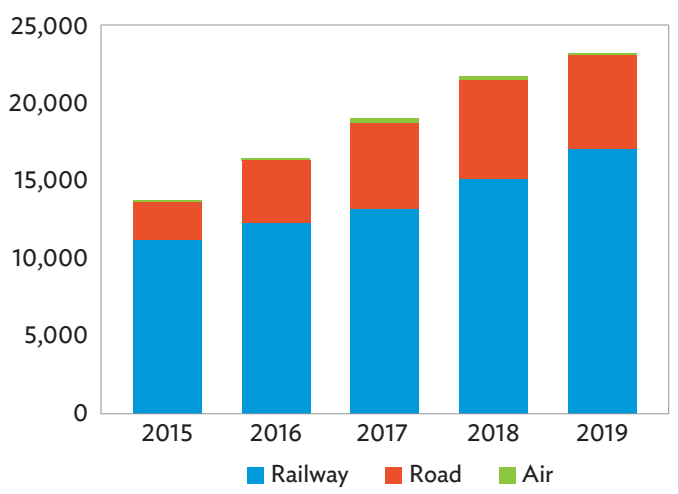


than double throughput capacity of this mainline-a necessary move as 2019 freight tonnage has already exceeded the rail capacity limit of this trunk line ( 25 million tons). ${ }^{43}$

\section{Recommendations}

(i) Expand freight capacity of the rail trunk line (corridor 4b). Total freight tonnage in 2019 transported by rail exceeded 28 million tons, which was beyond the capacity of the infrastructure designed at 25 million tons. This could affect the average speed of the trains on corridor $4 \mathrm{~b}$ if the infrastructure is not upgraded. According to CPMM estimates, 2016-2018 SWOD was $33.2 \mathrm{~km} / \mathrm{h}$ (2016), $22.7 \mathrm{~km} / \mathrm{h}$ (2017), and $20.9 \mathrm{~km} / \mathrm{h}$ (2018), which confirms a slowing overall average train movement despite the increase to $24.1 \mathrm{~km} / \mathrm{h}$ in 2019 .

(ii) Expand cargo handling capacity at Zamiin-Uud. Average border-crossing time at Zamiin-Uud during 2017-2019 for inbound cargo was 18.9 hours (2017), 22.9 hours (2018), and 24.2 hours (2019). Inbound time was consistently more than double that of outbound time. While gauge change operations (a normal cause for delay) took only 1.7 hours in 2019, the reason for delay in this case was restriction on entry and waiting for priority trains to pass, reasons normally tied to the handling capacity of the rail terminal. Equipment upgrade, more sidings, and an expanded shunting system could improve the situation.

(iii) Address the shortage of railway wagons. Although reported in the CPMM 2018 Annual Report, the situation did not improve in 2019 when the shortage of wagons contributed to average delay times of up to 25 hours.

\section{Pakistan}

\section{Key Findings}

(i) CPMM TFIs reported longer average border-crossing time, although relatively unchanged average border-crossing cost. Total average transport cost showed an improvement, but both measures of speeds showed that trucks did not move as fast compared to 2018.

(ii) Average border-crossing time increased to 38.2 hours. The time to cross Chaman was 60.1 hours, ranked as the most time-consuming BCP in 2019; Peshawar took 45.8 hours, and ranked the third most time-consuming. These samples were estimated from commercial shipments carrying goods destined for Afghanistan as well as Central Asia.

(iii) Average border-crossing costs remained comparatively unchanged. Peshawar in subcorridor $5 a$ averaged $\$ 319$ to complete border crossing in 2019, while Chaman in subcorridor 5c was lower at $\$ 156$.

\section{Trends and Developments}

Following the approval of its National Transport Policy in 2018, Pakistan embarked on a series of reform and initiatives to address structural inefficiencies and impediments, to increase exports through lowering cost and lead time of transportation. One important reform was mutual agreement between Afghanistan and Pakistan in September 2019 for both sides to operate 24/7 at Torkham BCP.44 Intended to increase bilateral and transit trade, border-crossing times were immediately shortened: CPMM data (Figure 6.2) showed pre-agreement samples from July-August 2019 at an average time of 12 hours at Peshawar,

43 United Nations Economic and Social Commission for Asia and the Pacific (UNESCAP). 2018. Facilitation Measures For International Railway Transport, At Railway Border Crossings, And On Technical Standards And Operational Practices Along International Corridor In Mongolia. https:// www.unescap.org/sites/default/files/Country-Mongolia_HLEGM.pdf.

44 Dawn. 2019. 'Historic day': PM Imran inaugurates 24/7 border crossing at Torkham. https://www.dawn.com/news/1505914 
Table 6.15 Trade Facilitation Indicators for Pakistan

\begin{tabular}{|c|c|c|c|c|c|c|c|c|c|}
\hline & \multicolumn{3}{|c|}{ Road Transport } & & \multicolumn{3}{|c|}{ Rail Transport } & \\
\hline & & 2017 & 2018 & 2019 & & 2017 & 2018 & 2019 & \\
\hline \multirow[t]{3}{*}{ TFI1 } & Time taken to clear a border-crossing point (hour) & 56.9 & 36.3 & 45.6 & $\bullet$ & - & - & - & - \\
\hline & Outbound & 59.2 & 37.8 & 47.3 & & - & - & - & \\
\hline & Inbound & 1.2 & 2.1 & 1.8 & & - & - & - & \\
\hline \multirow[t]{3}{*}{ TFI2 } & Cost incurred at border-crossing clearance $(\$)$ & 280.0 & 282.0 & 283 & $\bullet$ & - & - & - & - \\
\hline & Outbound & 280.0 & 286.0 & 287 & & - & - & - & \\
\hline & Inbound & - & 16.0 & 16 & & - & - & - & \\
\hline TFI3 & $\begin{array}{l}\text { Cost incurred to travel a corridor section } \\
(\$ \text {, per } 500 \mathrm{~km} \text {, per } 20 \text {-ton cargo) }\end{array}$ & $1,875.0$ & 727.0 & 704 & $\bullet$ & - & - & - & - \\
\hline TFI4 & Speed to travel on CAREC corridors $(\mathrm{km} / \mathrm{h})$ & 9.8 & 13.7 & 10.5 & $\bullet$ & - & - & - & - \\
\hline SWOD & Speed without delay $(\mathrm{km} / \mathrm{h})$ & 50.4 & 39.5 & 28.2 & $\bullet$ & - & - & - & - \\
\hline
\end{tabular}

Legend: - Improved by at least 3\% - Deteriorated by at least 3\% - Insignificant change [-3\% to 3\%]

- = no data, CAREC $=$ Central Asia Regional Economic Cooperation, $\mathrm{km}=$ kilometer, $\mathrm{km} / \mathrm{h}=$ kilometer per hour, $\mathrm{SWOD}=$ speed without delay, $\mathrm{TFI}=$ trade facilitation indicator.

Source: Asian Development Bank.

Table 6.16: Border-Crossing Performance in Pakistan

\begin{tabular}{|c|c|c|c|c|c|c|c|c|}
\hline \multirow[b]{2}{*}{ BCP } & \multirow[b]{2}{*}{ Corridor } & \multirow{2}{*}{$\begin{array}{l}\text { Direction } \\
\text { of Trade }\end{array}$} & \multicolumn{3}{|c|}{$\begin{array}{l}\text { Duration } \\
\text { (hours) }\end{array}$} & \multicolumn{3}{|c|}{$\begin{array}{l}\text { Cost } \\
(\$)\end{array}$} \\
\hline & & & 2017 & 2018 & 2019 & 2017 & 2018 & 2019 \\
\hline \multicolumn{9}{|c|}{ Road Transport } \\
\hline \multirow[t]{2}{*}{ Chaman } & \multirow[t]{2}{*}{5,6} & Outbound & 82.2 & 65.2 & 60.1 & 100 & 117 & 156 \\
\hline & & Inbound & - & - & - & - & 5 & - \\
\hline Peshawar & 5,6 & Outbound & 57.6 & 33.5 & 35.7 & 318 & 320 & 319 \\
\hline \multirow[t]{2}{*}{ Khunjerab } & \multirow[t]{2}{*}{5} & Outbound & 57.6 & 33.5 & - & 318 & 320 & - \\
\hline & & Inbound & 1.2 & 2.1 & 1.8 & - & 5 & 5 \\
\hline
\end{tabular}

- = no data, $\mathrm{BCP}=$ border-crossing point.

Source: Asian Development Bank.

Figure 6.2: Estimated Waiting Time in Line at Peshawar and Torkham Border-Crossing Points before and after 24/7 Implementation

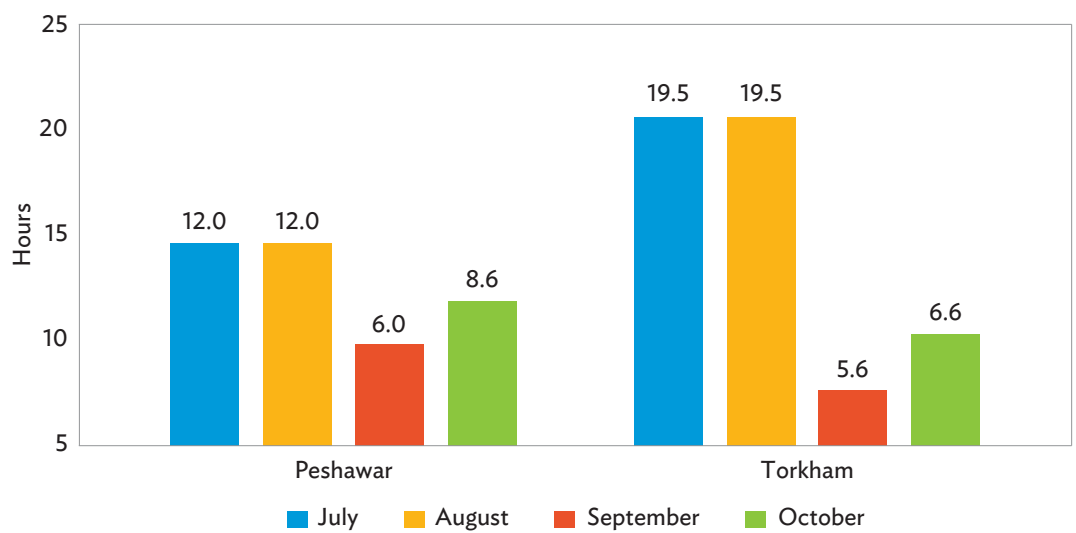

Source: Asian Development Bank. 
and 19.5 hours at Torkham. After 24/7 implementation, the average waiting time dropped to 6 hours in September and 8.6 hours in October at Peshawar, and 5.6 hours in September and 6.6 hours in October at Torkham. Similarly, average waiting times post-agreement fell to 7.3 hours (Peshawar) and 6.1 hours (Torkham).

Pakistan made notable achievements in 2019 in advancing transit trade. The CMR came into force on 28 August 2019.45 Furthermore, the Ministry of Commerce notified on 15 October 2019 that Gwadar seaport-in addition to Karachi seaport and Port Qassim -is able to handle Afghan transit trade. ${ }^{46}$ This will address long dwell times at Karachi seaport, as identified by CPMM data, where customs clearance controls can take 4-5 days. The Federal Bureau of Revenue launched the national single window and authorized economic operator program, to help speed up border clearance. ${ }^{47}$

Notwithstanding efforts to reform, Pakistan continues to face severe challenges: for example, road transport moves $94 \%$ of total freight in the country, yet it remains the second most expensive mode of transport (after air). ${ }^{48}$ This was not helped by efforts of the Ministry of Communications in 2019 to introduce an axle load regime that set a maximum permissible weight limit for different types of trucks. Seen by transport associations and the trade community as yet one more structural cost (as more trucks would be needed to move the same amount of goods), further consideration of this policy has been pushed back to 2020 .

\section{Recommendations}

(i) Implement the national single window system and port community system (PCS) to reduce cargo dwell time in seaports. The CPMM has consistently identified that containers for Afghan transit trade experience significant dwell time in Karachi: implementation of a national single window system, proposal for which has been drafted by Pakistan authorities, and PCS should considerably decrease dwell time. ${ }^{49}$

(ii) Adoption of an AEO program. The Federal Bureau of Revenue and Pakistan Customs are developing an AEO program which will adopt risk-based management and improve the efficiency of cross-border trade. Once established, Pakistan's AEO program could explore opportunities for mutual recognition arrangements in AEO with other CAREC member countries.

(iii) Develop TIR parks close to high-traffic BCPs. Border-crossing time at Torkham and Chaman BCPs remain elevated, despite 24/7 operations at Torkham. CPMM information indicates the lack of well-designed parking areas at BCPs as a contributory factor to obstruction of vehicles and delays. Better parking area design and queuing systems could improve efficiency and speed up border crossing.

(iv) Ratify the International Carriage of Goods on Road Act. Pakistan does not yet have a domestic regulation on the international carriage of goods on road, which is a fundamental condition to implement the CMR. This regulation should also recognize the role of insurers in underwriting a limited liability for road carriers. This would standardize such practice in the country and formalize the treatment of claims.

(v) Promote other modes of transport for freight. Pakistan's over-reliance on road transport increases the cost of freight and is not sustainable. Greater adoption of freight on rail and inland waterways would reduce freight costs and boost low-unit value exports such as agricultural produce. Pakistan

45 The CMR makes available and enforceable international standards on carrier liability and dispute resolution, and offers Pakistan transport operators additional protection when conducting cross-border shipments. United Nations Economic Commission for Europe. http://www.unece.org/fileadmin/ DAM/trans/conventn/depnots/2019-236e.pdf.

46 Ministry of Commerce. "Implementation of Export and Import Policy Order." dated 15 October 2019

47 Federal Board of Revenue. http://download1.fbr.gov.pk/Docs/2019721571628176FirstDraftPSWAct-2nd July,2019(1).pdf.

48 Ministry of Planning Development and Special Initiatives. https://www.pc.gov.pk/uploads/plans/Ch27-Transport-logistics2.pdf.

49 The Pakistan Single Window Act, 2019. http://download1.fbr.gov.pk/Docs/2019721571628176FirstDraftPSWAct-2ndJuly,2019(1).pdf. 
Railways created a freight transportation company that focuses on cargo and started freight train services between Karachi and Lahore. Private investment could be encouraged to attract more funding for a greater number of locomotives and railcars, to increase the capacity of this rail transport option. To spearhead inland waterways, the creation of a national inland waterways transport authority would be the first step.

\section{Tajikistan}

\section{Key Findings}

(i) CPMM data showed mixed results for Tajikistan: road transporters reported an increase in average border-crossing time from 3.8 hours in 2018 to 4.3 hours in 2019, driven by delays at Panji Poyon $\mathrm{BCP}$, where incoming traffic from Afghanistan experienced long waiting times.

(ii) Average border-crossing cost dropped from $\$ 118$ in 2018 to $\$ 105$ in 2019. Total average transport cost, on the other hand, rose from $\$ 589$ (2018) to $\$ 629$ (2019), inferring an increase in trucking rates in Tajikistan in 2019.

(iii) Speed remained largely the same as in 2018: average SWOD was estimated at $39.6 \mathrm{~km} / \mathrm{h}$ in 2019, very close to $39.5 \mathrm{~km} / \mathrm{h}$ in 2018; and average SWD reduced slightly from $23.3 \mathrm{~km} / \mathrm{h}$ (2018) to $22.5 \mathrm{~km} / \mathrm{h}$ (2019).

\section{Trends and Developments}

In 2019, Tajikistan made a series of changes to legislation and improvements to infrastructure designed to improve trade and transit. For example, Tajikistan embarked on necessary legislative and other adjustments in support of implementation of the TIR Electronic Pre-Declaration (TIR EPD) which will improve data flows between transport operators, customs authorities, and the International Road Transport Union. In addition, Tajikistan Customs piloted a national single window component to be integrated with TIREPD. In 2019, Tajikistan acceded to the Electronic CMR (e-CMR), with the aim of increasing transparency and efficiency of road transport insurance.

Table 6.17: Trade Facilitation Indicators for Tajikistan

\begin{tabular}{|c|c|c|c|c|c|c|c|c|c|}
\hline & & \multicolumn{3}{|c|}{ Road Transport } & & \multicolumn{3}{|c|}{ Rail Transport } & \\
\hline & & 2017 & 2018 & 2019 & & 2017 & 2018 & 2019 & \\
\hline \multirow[t]{3}{*}{ TFI1 } & Time taken to clear a border-crossing point (hour) & 3.8 & 3.8 & 4.3 & $\bullet$ & - & 2.3 & - & $\bullet$ \\
\hline & Outbound & 2.1 & 4.0 & 4.4 & & - & - & - & \\
\hline & Inbound & 4.4 & 3.7 & 4.2 & & - & 2.3 & - & \\
\hline \multirow[t]{3}{*}{ TFI2 } & Cost incurred at border-crossing clearance $(\$)$ & 103.0 & 118.0 & 105 & - & - & 65.0 & - & - \\
\hline & Outbound & 20.0 & 162.0 & 65 & & - & - & - & \\
\hline & Inbound & 131.0 & 98.0 & 122 & & - & 65.0 & - & \\
\hline TFI3 & $\begin{array}{l}\text { Cost incurred to travel a corridor section } \\
(\$, \text { per } 500 \mathrm{~km} \text {, per } 20 \text {-ton cargo })\end{array}$ & 854.0 & 589.0 & 629 & - & - & - & - & - \\
\hline TFI4 & Speed to travel on CAREC corridors $(\mathrm{km} / \mathrm{h})$ & 23.1 & 23.3 & 22.5 & - & - & - & - & - \\
\hline SWOD & Speed without delay $(\mathrm{km} / \mathrm{h})$ & 39.6 & 39.5 & 39.6 & - & - & - & - & - \\
\hline
\end{tabular}

Legend: Improved by at least 3\% Deteriorated by at least 3\% Insignificant change [-3\% to 3\%]

- = no data, CAREC = Central Asia Regional Economic Cooperation, $\mathrm{km}=$ kilometer, $\mathrm{km} / \mathrm{h}=$ kilometer per hour, SWOD $=$ speed without delay, $\mathrm{TFI}=$ trade facilitation indicator.

Source: Asian Development Bank. 
Table 6.18: Border-Crossing Performance in Tajikistan

\begin{tabular}{|c|c|c|c|c|c|c|c|c|}
\hline \multirow[b]{2}{*}{ BCP } & \multirow[b]{2}{*}{ Corridor } & \multirow{2}{*}{$\begin{array}{l}\text { Direction } \\
\text { of Trade }\end{array}$} & \multicolumn{3}{|c|}{$\begin{array}{l}\text { Duration } \\
\text { (hours) }\end{array}$} & \multicolumn{3}{|c|}{$\begin{array}{l}\text { Cost } \\
(\$)\end{array}$} \\
\hline & & & 2017 & 2018 & 2019 & 2017 & 2018 & 2019 \\
\hline \multicolumn{9}{|c|}{ Road Transport } \\
\hline \multirow[t]{2}{*}{ Dusti } & \multirow[t]{2}{*}{3} & Outbound & - & 11.0 & 11.0 & - & 109 & 108 \\
\hline & & Inbound & 3.9 & 3.8 & 3.2 & 123 & 105 & 96 \\
\hline \multirow[t]{2}{*}{ Fotehobod } & \multirow[t]{2}{*}{$2,3,6$} & Outbound & - & 1.4 & - & - & 27 & - \\
\hline & & Inbound & 7.5 & 7.0 & 1.9 & 87 & 300 & 476 \\
\hline \multirow[t]{2}{*}{ Panji Poyon } & \multirow[t]{2}{*}{$2,5,6$} & Outbound & 2.1 & 3.3 & 3.8 & 20 & 175 & 61 \\
\hline & & Inbound & 6.5 & 5.6 & 7.2 & 102 & 125 & 183 \\
\hline \multirow[t]{2}{*}{ Karamyk } & \multirow[t]{2}{*}{$2,3,5$} & Outbound & 3.4 & 1.2 & 1.2 & 33 & 28 & 37 \\
\hline & & Inbound & 0.3 & 1.0 & 0.6 & 42 & 27 & 26 \\
\hline \multirow[t]{2}{*}{ Guliston } & \multirow[t]{2}{*}{ n.a. } & Outbound & - & 1.4 & 0.9 & - & 34 & 29 \\
\hline & & Inbound & - & 1.2 & 0.6 & - & 27 & 21 \\
\hline \multirow[t]{2}{*}{ Kulma } & \multirow[t]{2}{*}{ n.a. } & Outbound & - & - & - & - & - & - \\
\hline & & Inbound & 2.4 & 2.8 & 3.0 & 210 & 84 & 91 \\
\hline \multirow[t]{2}{*}{ Jalgan } & \multirow[t]{2}{*}{$2,3,5$} & Outbound & - & - & - & - & - & - \\
\hline & & Inbound & - & 0.3 & 0.6 & - & 42 & 99 \\
\hline \multicolumn{9}{|c|}{ Rail Transport } \\
\hline \multirow[t]{2}{*}{$\mathrm{Nau}$} & \multirow[t]{2}{*}{2} & Outbound & - & - & - & - & - & - \\
\hline & & Inbound & - & 2.6 & - & - & - & - \\
\hline
\end{tabular}

- = no data, $\mathrm{BCP}=$ border-crossing point, n.a. = not applicable

Source: Asian Development Bank.

In March 2019, Tajikistan and Georgia signed a draft agreement on international road transport, which provides the framework for bilateral, transit, or via third-party movements based on quota permits. ${ }^{50}$ This type of agreement facilitates cross-border trade, especially the transportation of heavy machineries and equipment for infrastructure projects in Tajikistan.

CPMM data highlighted inefficiencies of cross-border control in Tajikistan. For example, all transit shipments are escorted by customs, including TIR shipments, despite the TIR Convention clearly stating the waiver of this requirement. ${ }^{51}$ In addition, frequent physical checkpoints in Tajikistan add time and create opportunities for corrupt practices, especially during immigration and transport inspections.

\section{Recommendations}

(i) Remove customs escort for TIR shipment. This continuing problem has not been addressed and added $\$ 130-\$ 200$ per truck under TIR operation to the cost of doing business. Customs escorts should be halted for TIR consignments.

(ii) Adopt risk-based and modern technologies to provide the necessary controls for import and transit shipments. While the Government of Tajikistan should be commended for embarking on development of a national single window and support for TIR-EPD, it should also consider developing an AEO program, and applying instruments and devices such as smart seals to prevent or detect tampering of shipments and combat smuggling.

\footnotetext{
50 Ministry of Economy and Sustainable Development, Republic of Georgia. http://www.moesd.gov.ge/?page=news\&nw=1068\&lang=en.

51 The cost of customs escort is approximately $\$ 2$ per $10 \mathrm{~km}$ of road travel.
} 
(iii) Encourage development of new corridors. Besides the Kulma Pass route, the private sector recommended developing the Shymkent-Tashkent-Khujand corridor. ${ }^{52}$ This would benefit the Tajiks in the Sughd region and also promote greater regional trade between Tajikistan, Uzbekistan, and Kazakhstan.

\section{Turkmenistan}

\section{Key Findings}

(i) Turkmenistan serves as an important transit country for traffic between Iran and Central Asia and 2019 CPMM data continued to track cargo between Sarakhs-Sarahs on the Iran-Turkmenistan border, and Farap-Alat on the Turkmenistan-Uzbekistan border.

(ii) Border-crossing time and cost indicators deteriorated, while speed indicators remained relatively the same. The average time to clear a BCP increased from 8.5 hours for road and from 3.3 hours for rail in 2018, to 9.0 hours for road and 3.5 hours for rail in 2019. The average BCP clearance cost increased from $\$ 204$ for road and from $\$ 94$ for rail in 2018 , to $\$ 211$ for road and $\$ 97$ for rail in 2019. The cost of travel for road increased by about $8 \%$ in 2019 , although dropped slightly for rail. SWD and SWOD showed no significant change during 2018-2019.

\section{Trends and Developments}

The imposition of sanctions by the US against Iran continued to heavily impact freight between Central Asia and Iran, which normally transits Turkmenistan (footnote 41). Consequently, a large percentage of the traffic moving between Central Asia and Bandar Abbas Port was shifted to the Georgian ports of Poti and Batumi.

The random embargo of Tajik rail and truck cargo also removed a portion of transit traffic, causing Tajik shippers to incur large increases in transport cost by routing their cargo through much more circuitous routes.

Railways of Azerbaijan and Kazakhstan, as well as their Caspian Sea shipping lines and ports, have organized the Trans-Caspian International Transport Route with Georgian Railway to promote a corridor aligned with CAREC corridor 2c. ${ }^{53}$

\section{Recommendations}

(i) Attract more traffic to Turkmenbashi seaport. The Turkmenbashi seaport is closer to Baku for Uzbekistan, Tajikistan, and Afghanistan and, hence, well-positioned to attract traffic from these countries. The Government of Turkmenistan has invested heavily to modernize the port infrastructure and shipping capacity. Turkmenistan should simplify the process for foreign shippers to use this port to attract more transit traffic.

(ii) Develop logistics capacity of mid-level government officials and industry management. Logistics capacity in Turkmenistan remains weak and the industry would benefit from development of relevant technical and managerial courses to improve understanding and application. Priority areas of expertise could include supply chain management, modern logistics systems, quality management principles, cold chain logistics management, and multimodal transport.

52 Previous CPMM reports described regular shipments from PRC-Tajikistan-Afghanistan via the Kulma Pass, which avoids the need to cross the Kyrgyz Republic and, thus, serves as an alternative trade route linking East Asia to Afghanistan and the Middle East.

53 The Trans-Caspian International Transport Route starts from Southeast Asia and the PRC, runs through Kazakhstan, the Caspian Sea, Azerbaijan, Georgia, and further to European countries. 
Table 6.19: Trade Facilitation Indicators for Turkmenistan

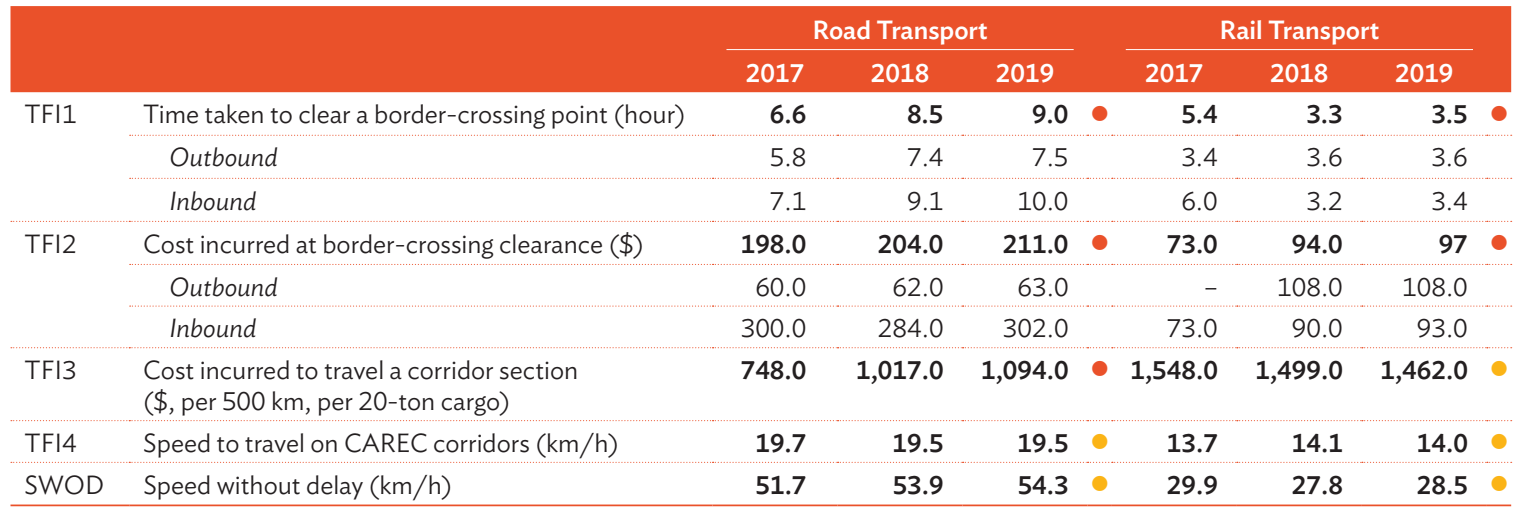

Legend: Deteriorated by at least 3\% Insignificant change [-3\% to 3\%]

- = no data, $\mathrm{CAREC}=$ Central Asia Regional Economic Cooperation, $\mathrm{km}=$ kilometer, $\mathrm{km} / \mathrm{h}=$ kilometer per hour, SWOD $=$ speed without delay, $\mathrm{TFI}=$ trade facilitation indicator.

Source: Asian Development Bank.

Table 6.20: Border-Crossing Performance in Turkmenistan

\begin{tabular}{|c|c|c|c|c|c|c|c|c|}
\hline \multirow[b]{2}{*}{ BCP } & \multirow[b]{2}{*}{ Corridor } & \multirow{2}{*}{$\begin{array}{c}\text { Direction } \\
\text { of Trade }\end{array}$} & \multicolumn{3}{|c|}{$\begin{array}{l}\text { Duration } \\
\text { (hours) }\end{array}$} & \multicolumn{3}{|c|}{$\begin{array}{l}\text { Cost } \\
(\$)\end{array}$} \\
\hline & & & 2017 & 2018 & 2019 & 2017 & 2018 & 2019 \\
\hline \multicolumn{9}{|c|}{ Road Transport } \\
\hline \multirow[t]{2}{*}{ Sarahs } & 3 & Outbound & - & 7.4 & 7.6 & - & 64 & 62 \\
\hline & & Inbound & 6.2 & 9.0 & 9.4 & 300 & 311 & 317 \\
\hline \multirow[t]{2}{*}{ Farap } & 0 & Outbound & - & - & - & - & - & - \\
\hline & & Inbound & - & - & - & - & - & - \\
\hline \multirow[t]{2}{*}{ Farap } & 2,3 & Outbound & 5.8 & 7.4 & 7.5 & 58 & 62 & 63 \\
\hline & & Inbound & 7.9 & 9.8 & 10.2 & 300 & 296 & 298 \\
\hline \multirow[t]{2}{*}{ Farap } & 2 & Outbound & - & - & - & - & - & - \\
\hline & & Inbound & - & - & 6.0 & - & - & - \\
\hline \multirow[t]{2}{*}{ Farap } & 2,6 & Outbound & - & - & - & - & - & - \\
\hline & & Inbound & - & 2.3 & - & - & 50 & - \\
\hline \multicolumn{9}{|c|}{ Rail Transport } \\
\hline \multirow[t]{2}{*}{ Farap } & 2,3 & Outbound & - & - & - & - & - & - \\
\hline & & Inbound & 2.9 & 2.6 & 2.7 & 127 & 119 & 120 \\
\hline \multirow[t]{2}{*}{ Farap } & 2,6 & Outbound & - & - & - & - & - & - \\
\hline & & Inbound & 7.4 & 3.5 & 3.7 & 50 & 77 & 82 \\
\hline
\end{tabular}

- = no data, $\mathrm{BCP}=$ border-crossing point.

Source: Asian Development Bank. 


\section{Uzbekistan}

\section{Key Findings}

(i) CPMM 2019 data found the average BCP clearance time for road cargo dropped from 8.5 hours in 2018 to 7.8 hours in 2019, but average rail cargo clearance time increased from 5.6 hours (2018) to 6.2 hours (2019). The average cost for road border clearance rose from $\$ 73$ in 2018 to $\$ 87$ in 2019 , and the average cost for rail border clearance remained relatively unchanged from $\$ 112$ (2018) to $\$ 113$ (2019).

(ii) The average road transport cost for traveling a 500-km segment of Uzbek corridors increased from $\$ 477$ in 2018 to $\$ 600$ in 2019, while rail transport cost dropped from $\$ 971$ (2018) to $\$ 778$ (2019).

(iii) For road traffic, the average SWD and SWOD showed insignificant changes. For rail traffic, the average SWD decreased from $14.0 \mathrm{~km} / \mathrm{h}$ (2018) to $10.5 \mathrm{~km} / \mathrm{h}$ (2019), despite SWOD increasing from $27.9 \mathrm{~km} / \mathrm{h}$ (2018) to $38.2 \mathrm{~km} / \mathrm{h}$ (2019).

\section{Trends and Developments}

The Government of Uzbekistan implemented a series of important reforms in 2019, including several economic development and promotion of entrepreneurship reforms. ${ }^{54} \mathrm{~A}$ new law to guarantee unimpeded transfer of foreign currency abroad and protection of assets from nationalization and expropriation was enacted in December 2019.55

Uzbek Customs made significant progress toward process simplification, with $84 \%$ of exported fruit and vegetable shipments now cleared though the green lane (footnote 41). It also introduced an AEO program which grants simplified declarations and clearance to entities complying with Uzbek Customs standards. ${ }^{56}$ Uzbekistan also plans to modernize and enhance throughput at the following border ports: Daut-Ota,

Table 6.21: Trade Facilitation Indicators for Uzbekistan

\begin{tabular}{|c|c|c|c|c|c|c|c|c|c|}
\hline & & \multicolumn{3}{|c|}{ Road Transport } & & \multicolumn{4}{|c|}{ Rail Transport } \\
\hline & & 2017 & 2018 & 2019 & & 2017 & 2018 & 2019 & \\
\hline \multirow[t]{3}{*}{ TFI1 } & Time taken to clear a border-crossing point (hour) & 5.8 & 8.5 & 7.8 & - & 7.5 & 5.6 & 6.2 & 0 \\
\hline & Outbound & 5.6 & 8.5 & 7.9 & & 15.5 & 11.1 & 14.0 & \\
\hline & Inbound & 6.1 & 8.5 & 7.7 & & 2.7 & 3.6 & 4.0 & \\
\hline \multirow[t]{3}{*}{ TFI2 } & Cost incurred at border-crossing clearance $(\$)$ & 88.0 & 73.0 & 88 & $\bullet$ & 112.0 & 112.0 & 113 & $\bullet$ \\
\hline & Outbound & 80.0 & 66.0 & 92 & & 98.0 & 99.0 & 99 & \\
\hline & Inbound & 96.0 & 80.0 & 84 & & 120.0 & 118.0 & 119 & \\
\hline TFI3 & $\begin{array}{l}\text { Cost incurred to travel a corridor section } \\
(\$, \text { per } 500 \mathrm{~km} \text {, per } 20 \text {-ton cargo) }\end{array}$ & 23.0 & 477.0 & 600 & $\bullet$ & $1,138.0$ & 971.0 & 778 & $\bullet$ \\
\hline TFI4 & Speed to travel on CAREC corridors $(\mathrm{km} / \mathrm{h})$ & 28.0 & 28.5 & 28.6 & - & 10.0 & 14.0 & 10.5 & - \\
\hline SWOD & Speed without delay $(\mathrm{km} / \mathrm{h})$ & 46.8 & 50.8 & 50.0 & $\bullet$ & 25.3 & 27.9 & 38.2 & $\bullet$ \\
\hline
\end{tabular}

Legend: - Improved by at least 3\% - Deteriorated by at least 3\% Insignificant change [-3\% to 3\%]

CAREC $=$ Central Asia Regional Economic Cooperation, $\mathrm{km}=$ kilometer, $\mathrm{km} / \mathrm{h}=$ kilometer per hour, SWOD = speed without delay, $\mathrm{TFI}=$ trade facilitation indicator.

Source: Asian Development Bank

\footnotetext{
54 The Economist. 21 December 2019.

55 Law No. ZRU-598 "Regarding Investments and Investment Activities."

56 Resolution No. 363 of the Cabinet of Ministers signed in April 2019.
} 
Table 6.22: Border-Crossing Performance in Uzbekistan

\begin{tabular}{|c|c|c|c|c|c|c|c|c|}
\hline \multirow[b]{2}{*}{$\mathrm{BCP}$} & \multirow[b]{2}{*}{ Corridor } & \multirow{2}{*}{$\begin{array}{l}\text { Direction } \\
\text { of Trade }\end{array}$} & \multicolumn{3}{|c|}{$\begin{array}{l}\text { Duration } \\
\text { (hours) }\end{array}$} & \multicolumn{3}{|c|}{$\begin{array}{l}\text { Cost } \\
(\$)\end{array}$} \\
\hline & & & 2017 & 2018 & 2019 & 2017 & 2018 & 2019 \\
\hline \multicolumn{9}{|l|}{ Road Transport } \\
\hline \multirow[t]{2}{*}{ Alat } & 2,3 & Outbound & 6.1 & 9.1 & 9.5 & - & - & - \\
\hline & & Inbound & 5.3 & 9.8 & 9.8 & - & - & - \\
\hline \multirow[t]{2}{*}{ Termez } & 3,6 & Outbound & - & - & 2.3 & - & - & - \\
\hline & & Inbound & - & - & - & - & - & - \\
\hline \multirow[t]{2}{*}{ Dustlik } & 2 & Outbound & - & 1.0 & 0.9 & - & 22 & 23 \\
\hline & & Inbound & - & 1.1 & 0.6 & - & 27 & 20 \\
\hline \multirow[t]{2}{*}{ Dautota } & 2,6 & Outbound & 6.9 & 6.9 & 9.6 & - & - & 10 \\
\hline & & Inbound & 6.1 & 6.2 & 7.6 & 108 & 96 & 84 \\
\hline \multirow[t]{2}{*}{ Saryasia } & 3 & Outbound & 4.1 & 5.1 & 4.6 & 81 & 76 & 101 \\
\hline & & Inbound & - & 10.0 & 10.1 & - & - & - \\
\hline \multirow[t]{2}{*}{ Yallama } & 3,6 & Outbound & 6.5 & 10.2 & 10.0 & - & - & 54 \\
\hline & & Inbound & - & - & 1.3 & - & - & 10 \\
\hline \multirow[t]{2}{*}{ Uchkurgan } & 0 & Outbound & - & - & 3.0 & - & - & - \\
\hline & & Inbound & - & - & - & - & - & - \\
\hline \multirow[t]{2}{*}{ Oibek } & $2,3,6$ & Outbound & 6.8 & 5.0 & 1.3 & - & 15 & - \\
\hline & & Inbound & - & 2.8 & - & - & 32 & - \\
\hline \multirow[t]{2}{*}{ Saryasia } & 3 & Outbound & 4.1 & 5.1 & 4.6 & 81 & 76 & 101 \\
\hline & & Inbound & - & 10.0 & 10.1 & - & - & - \\
\hline \multirow[t]{2}{*}{ Yallama } & 3,6 & Outbound & 6.5 & 10.2 & 10.0 & - & - & 54 \\
\hline & & Inbound & - & - & 1.3 & - & - & 10 \\
\hline \multicolumn{9}{|l|}{ Rail Transport } \\
\hline \multirow[t]{2}{*}{ Termez } & 3,6 & Outbound & - & 0.6 & - & - & - & - \\
\hline & & Inbound & - & 8.3 & 8.9 & - & 117 & 119 \\
\hline \multirow[t]{2}{*}{ Keles } & 3,6 & Outbound & - & - & - & - & - & - \\
\hline & & Inbound & 2.7 & 2.4 & 2.4 & 120 & 119 & 119 \\
\hline \multirow[t]{2}{*}{ Bekabad } & 2 & Outbound & - & 4.3 & - & - & - & - \\
\hline & & Inbound & - & - & - & - & - & - \\
\hline \multirow[t]{2}{*}{ Khodzhadavlet } & 2,3 & Outbound & - & 15.1 & 15.0 & - & 100 & 100 \\
\hline & & Inbound & - & - & - & - & - & - \\
\hline
\end{tabular}

- = no data, $\mathrm{BCP}=$ border-crossing point. Source: Asian Development Bank.

Yallama, S. Najimov, Gishtkuprik, Oybek, Dustlik, Madaniat, and Olot using the public-private partnership financing mode. ${ }^{57}$

Uzbekistan also established a Ministry of Transport, ${ }^{58}$ responsible for policy related to rail, road, air, and metro transport, ${ }^{59}$ continued support to its well-managed national rail network (O’zbekiston Temir Yo'llari [UTY]); formulated policies to grow its trucking industry; ${ }^{60}$ and accelerate procurement of temperaturecontrolled vehicles for Uzbek agricultural exports. Policies of note include various tax exemptions (e.g., duty-free import of used European truck); low interest rate loans; and simplification of the process to obtain licenses, permits, and certificates (e.g., certificate of origin and quality).

57 LexUz. On Additional Measures to Improve Customs Administration and Increase the Efficiency of the State Customs Service of the Republic of Uzbekistan. https://lex.uz/ru/docs/4076902.

58 LexUz. On Measures to Radically Improve the Public Administration System in the Field of Transport. https://lex.uz/ru/docs/4194115.

59 For more information, see Ministry of Transport of the Republic of Uzbekistan. http://mintrans.uz/en/.

60 LexUz. On Additional Measures for the Further Development of International Road Transport of Goods. https://lex.uz/ru/docs/4368028. 


\section{Recommendations}

(i) Enhance wagon supply on UTY network. Although UTY faces shortages of railway wagons, including container platforms, it has successfully managed this challenge by using wagons from other countries, especially privately owned wagons from Belarus, Kazakhstan, the Russian Federation, and Ukraine. However, to support further Uzbek economic growth, UTY should find other ways to enhance the wagon supply.

(ii) Improve UTY service quality. According to many freight forwarders, it is not easy to do business with UTY: problems cited include a lack of track-and-trace capacity, difficulty in ordering wagons, problem resolution delays and unexpected accessorial charges, antiquated paperbased procedures, and an inability to provide last-mile delivery. As domestic and regional freight markets become increasingly competitive, UTY should strengthen its service quality. 


\section{Corridor Performance \\ Measurement and Monitoring and Time Release Study Tools}

This chapter explores the common grounds shared by the CAREC CPMM and the World Customs Organization (WCO) time release study (TRS) tools, which both seek to measure the time and cost of specific trade facilitation activities with the ultimate aim of better informing government and relevant entities of priority reform and modernization steps.

\section{Background}

- CPMM: An empirical tool designed by CAREC to measure and track the time and cost of shipments across borders in the CAREC region and along CAREC corridors, using road and railway networks. Particular focus is given to border-crossing operations.

- TRS: A strategic and internationally recognized tool to measure the actual time required for the release and/or clearance of goods, from the time of arrival until the physical release of cargo, with a view to finding bottlenecks in the trade flow process and taking necessary measures to improve the effectiveness and efficiency of border procedures. ${ }^{61}$ TRS also measures the performance of the private sector in providing government agencies with sufficient information to release goods.

CAREC member countries have long recognized the merits of both the CAREC CPMM and the WCO TRS tools, defined above, for measuring and monitoring time and cost of trade facilitative activities (footnote 61). In 2017, CPMM and TRS experts, and CAREC customs administrations convened a workshop on the strategic use of CPMM and TRS mechanisms and explore how they could complement each other. ${ }^{62}$ For instance, how CPMM analysis-which highlights procedural and infrastructural impediments - could help identify specific BCPs along the CAREC corridors where application of the TRS tool would be valuable, together with the scope and scale of the TRS.

Workshop participants discussed in detail the principles, guidelines, phases, and tasks required to conduct TRS in accordance with WCO guidelines, and representatives from the Georgia Revenue Service (GRS) shared their experience of using the TRS tool, focusing on the methodology applied, the main findings from the TRS, and identification of key lessons learned.

Georgia has a strong track record of implementing effective trade facilitation reform, and in 2019, the country was ranked seventh out of 190 countries in the World Bank Doing Business Survey, and 45th in the specific metric "Trading Across Borders," both topping the rankings among CAREC member countries. ${ }^{63}$ These improvements could be attributed to:

(i) A national single window that automates trade procedures.

(ii) A modern border management strategy that adopts risk management.

(iii) Joint customs control with neighboring countries.

(iv) Upgraded infrastructure and equipment.

(v) Upgraded human capacity (customs and border agencies).

${ }_{61}$ WCO. Time Release Study - Version 3. http://www.wcoomd.org/en/topics/facilitation/instrument-and-tools/tools/time-release-study.aspx (accessed 25 February 2020).

${ }^{62}$ For details, see https://www.carecprogram.org/?event=workshop-time-release-study-corridor-performance-measurement-apr-2017. For workshop proceedings, see https://www.carecprogram.org/uploads/2014-At-the-Border.pdf.

63 World Bank. https:/www.doingbusiness.org/en/rankings\# 
GRS has also completed two TRS activities:

(i) During 4-11 November 2013, at the Sarpi BCP and the Tbilisi Customs Clearance Zone.

(ii) During 16-21 February 2016, at the Sarpi BCP, the Tbilisi Customs Clearance Zone, and at two major Black Sea ports: Poti (at both the seaport and the Free Industrial Zone) and Batumi (Batumi Customs Clearance Zone).

\section{Time Release Study Methodology}

All TRSs conducted in Georgia used the WCO TRS methodology and, in 2013, were guided by a WCOaccredited expert. TRS parameters in 2013 and 2016 were as follows:

(i) Only import and transit shipments were studied. Exports were perceived as comparatively simpler and of insufficient value to the TRS to be included.

(ii) Only customs and related procedures under customs controls were studied: effectively, customs procedures, passport control, and sanitary and phytosanitary (SPS) controls. Procedures outside of customs control, such as border security, were not included.

(iii) Both automated and manual procedures were studied.

(iv) Standard questionnaires were used, generally comprising binary responses (Yes/No) and recording of the start and end time for each specific step.

(v) A pilot study was organized during 7-9 October 2013 before the full TRS study to validate the methodology.

(vi) The sampling method chose every 10th commodity shipment over a continuous 24-hour period.

\section{Time Release Study Findings: Sarpi Border-Crossing Point and Poti}

Examination of TRS findings is limited to those conducted at Sarpi BCP, a major gateway for cross-border trade at the Georgia-Turkey border, and Poti. As nodes along CAREC corridor 2, both Sarpi and Poti are also covered by the CPMM tool. At Poti, both the seaports and the Free Industrial Zone were studied. Given that the CPMM only covered Poti seaport, the CPMM 2019 comparative analysis focused on Poti seaports only.

\section{Sarpi Findings}

In 2013, 188 trucks crossing Sarpi BCP were sampled under the TRS. Transit shipments were destined for Tsiteli Khidi and Lagodekhi BCPs at the border with Azerbaijan. In 2016, the sample size increased significantly to 757 trucks.

Both the 2013 and 2016 TRSs showed that documentary compliance took only 7 minutes or less to complete (Figure 7.1). In total, a transit shipment would complete all formalities in 10 minutes 42 seconds, which reflected the observations in CPMM where samples estimate also showed a similar duration of 10 minutes. A small number of shipments (estimated at $8 \%$ ) required physical inspection, for which estimated time for completion was calculated at 3 hours 33 minutes in 2013, and 5 hours 18 minutes in 2016 (Figure 7.2). 
Figure 7.1: Time Release Study Average Time to Complete Documentary Compliance at Sarpi

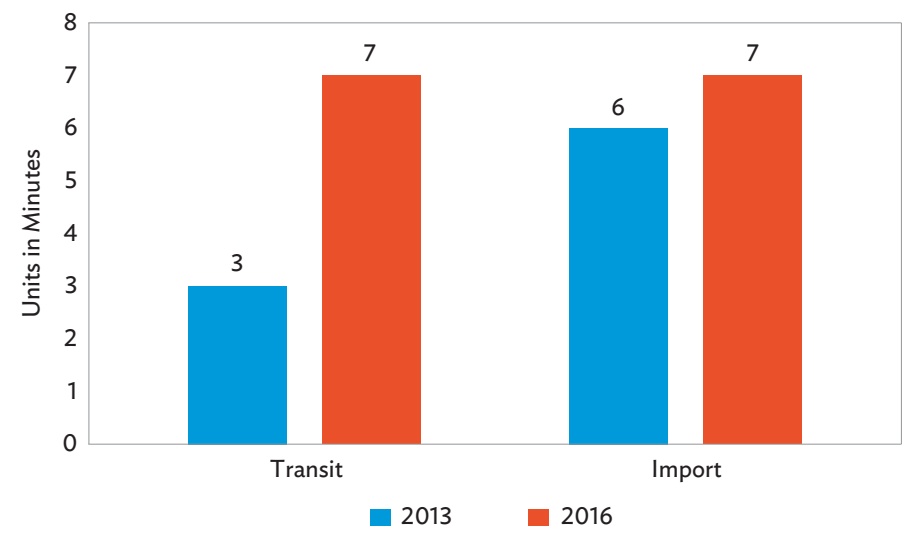

Source: Georgia Revenue Service. Time Release Study in Georgia, 2013 and 2016.

Figure 7.2: Time Release Study Average Time to Complete Physical Examinations at Sarpi

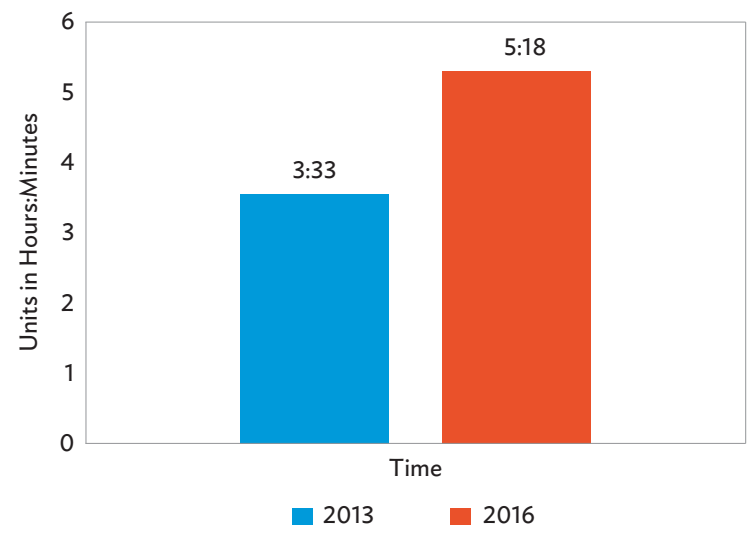

Source: Georgia Revenue Service. Time Release Study in Georgia, 2013 and 2016.

\section{Poti Findings}

Poti was included in the 2016 TRS and a total of 418 samples were studied (Table 7.1).

Table 7.1: Average Clearance Times for Poti, 2016

\begin{tabular}{lccc} 
Activities & Average Time & Minimum Time & Maximum Time \\
Customs Clearance & 1 minute & 1 minute & 7 minutes \\
Scanning & 3 minutes & 2 minutes & 5 minutes \\
Physical Inspection & 47 minutes & 47 minutes & 47 minutes \\
\hline
\end{tabular}

Source: Georgia Revenue Service. Time Release Study in Georgia, 2016. 
Customs clearance took only 1 minute, due to the use of computerized systems. In total, the container dwell time (the duration from discharge of container from vessel to the time it leaves the seaport) was estimated at 14 minutes. An additional 30 shipments were sampled from those that required further controls (scanning and/or physical inspection). Of these 30 samples, only one had to undergo physical inspection, which took 47 minutes.

Shipments where goods had to undergo sanitary and phytosanitary (SPS) controls were also studied at Sarpi and Poti. In general, the time taken for transit shipments was short, limited to 1 hour or less. However, import shipments that required SPS controls took significantly longer: 3-4 days.

\section{Key Lessons Learned from the Time Release Study}

(i) One-stop shop principle is very effective in simplifying border-crossing procedures.

(ii) Advanced declaration is moderately helpful to expedite border crossings.

(iii) Additional controls and SPS controls lengthened border-crossing time significantly.

\section{One-Stop Shop Principle}

In Georgia, the one-stop shop principle means that customs officers are empowered by law to handle immigration and selected parts of SPS controls. The design of the one-stop shop stations ensures that truck drivers do not need to park and exit their vehicles to complete the paperwork: they remain inside the truck throughout the process. On average, a truck can pass through Sarpi BCP within 10-15 minutes.

\section{Advanced Declaration}

Advanced declaration allows shippers to submit shipment data before the truck arrives, so that customs can make risk-based decisions, which may shorten border-crossing times. Similarly, advanced declaration also facilitates shipments to be cleared through a green channel, which shortens border-crossing time. The availability of full information can reduce the chances of the shipment being required to undergo additional controls or full physical examination, which considerably lengthens clearance times.

\section{Additional Controls and SPS Controls}

Additional controls included scanning and full physical control of vehicles. While most controls could be completed in under 20 minutes, the TRS reported that a full physical examination would take 3-5 hours. GRS continues to implement measures that reduce the need of such time-consuming activity so that shipments can flow with no friction.

\section{Comparison of Corridor Performance Measurement and Monitoring and Time Release Study}

Table 7.2 compares the basic distinguishing factors, and the similarities and differences between the CPMM and the TRS tools, in terms of methodology and findings.

While both tools adopt evidence-based methodology, it is useful to examine the differences so that the merits from each tool can be considered to improve the other one and also possibly complement the application, providing policy makers and researchers with a comprehensive assessment of corridors and border-crossing efficiencies. 
Table 7.2: Distinguishing Factors between the Corridor Performance Measurement and Monitoring and Time Release Study

\begin{tabular}{|c|c|c|}
\hline Factors & Time Release Study & CPMM \\
\hline Organization & - World Customs Organization & - Asian Development Bank \\
\hline Collected by & $\begin{array}{l}\text { - Customs officers, other border agencies } \\
\text { staff, and private sector stakeholders }\end{array}$ & - Transport operators \\
\hline Mode of Transport & - Any & - Focus on road and railways \\
\hline Start and End of Study & $\begin{array}{l}\text { Cargo arrival at port/BCP to the actual } \\
\text { release to cargo owners and movement } \\
\text { from the border }\end{array}$ & $\begin{array}{l}\text { - Loading of goods at origin to the unloading } \\
\text { of goods at final destination or BCP }\end{array}$ \\
\hline Data Collection Methodology & $\begin{array}{l}\text { - Online software, survey questionnaire, } \\
\text { interviews }\end{array}$ & $\begin{array}{l}\text { - Data collection forms, drivers form, } \\
\text { interviews }\end{array}$ \\
\hline
\end{tabular}

$\mathrm{BCP}=$ border-crossing point, $\mathrm{CPMM}=$ Corridor Performance Measurement and Monitoring.

Source: Asian Development Bank.

\section{Comparison of Methodologies}

Both tools share similarities in methodology applied:

(i) Both studies use actual commercial shipments to estimate border-crossing times.

(ii) The samples include import and transit shipments.

(iii) While BCPs are the primary focus of attention, both studies also include inland nodes (e.g., inland customs office) and seaports.

(iv) Customs controls is a principal area of study.

(v) Both studies use survey forms and collect the data by calculating the duration between start and end time, although the structure and format of the survey form may vary.

\section{Findings: Similarities and Differences}

\section{Similarities}

(i) Both studies tracked the direction of trade from Turkey to the Caucasus region or from Black Sea ports to the Caucasus. TRS in Georgia does not track the reverse direction, while limited CPMM samples followed shipments from Central Asia destined for Tbilisi in Georgia.

(ii) Both studies confirmed that the actual border crossings at Georgia were efficient, and trucks were able to pass through within 10-15 minutes.

(iii) Both studies verified that customs controls, immigration, and SPS (for transit) could be completed through a one-stop service.

(iv) Corruption was not evident in either the CPMM or TRS. Georgia has addressed corrupt behavior over the past decade, mainly by replacing customs personnel as necessary and ensuring elimination of corrupt practices.

\section{Differences}

(i) Time spent waiting in line for trucks is not tracked in TRS, but is captured through CPMM dataand found to be significant. For Sarpi, CPMM data estimated a range of 2-6 hours spent waiting in line at Sarpi before entry. 
(ii) TRS did not include Tsiteli Khidi BCP, which was covered under CPMM. After trucks completed formalities on the Georgian side, they proceeded to a no man's land and could wait for many hours before being able to enter the Azerbaijan side (Krasnyi Most).

(iii) TRS decomposed activities when trucks had to complete additional controls (including scanning and physical examination) at Poti, which the CPMM could not decompose and, thus, aggregated under "loading and unloading time." The CPMM reported a much longer dwell time in seaport for shipments compared to TRS: 4-6 hours compared to 14 minutes on average.

(iv) TRS included studies of shipments at the Customs Clearance Zone, a modern inland customs office used to process paperwork as well as the collection and redistribution of goods. Under the CPMM, the study stopped when the driver physically handed over the goods at the terminal node and did not collect data for collection and distribution activities.

(v) TRS focuses on import and transit, while CPMM includes import, transit, and export shipments.

(vi) CPMM reported major problems of delays and fees at Baku-Kuryk (trans-Caspian ferry) where the water crossing typically took several days. This is outside the scope of TRS and requires regional coordination.

\section{Complementarity between Corridor Performance Measurement and Monitoring and Time Release Study Tools}

Having understood the distinction between the two studies, it is possible to suggest how they could potentially complement each other. For example:

\section{Suggestion 1: Inputs for Scoping}

Figure 7.3 describes the high-level steps and data flow of how CPMM and TRS can reinforce each other and lead to better quality analysis. The inputs-process-output model illustrates specifically how CPMM could provide insights for TRS to consider the scope of specific studies (e.g., which BCPs to include) and how TRS could highlight previously unknown issues or areas that cannot be obtained from the existing CPMM methodology.

\section{Suggestion 2: Process Mapping}

TRS is able to map the process as customs officers are familiar with the various controls and are able to specify the activities and sequence in a visual manner (Figure 7.4). CPMM data collection, which depends on transport operators, is sometimes limited in its comprehension of the entire relevant customs code or ability to explain what happens to shipments in various scenarios, for example, when it is detained.

The topic of process mapping was raised in the CPMM Annual Report 2018, where the United Nations Economic and Social Commission for Asia and the Pacific (UNESCAP) business process analysis was adopted as the methodology for three case studies. Process maps using the Unified Modelling Language were used. The adoption of the modelling language could be a potentially new and useful application to model process maps. Such visual tools are very useful for policy makers and researchers to clearly understand the nature and location of specific problems.

\section{Suggestion 3: Insights on Customs Controls and Operations}

TRS is able to describe the duration of inspections and examinations, as well as SPS procedures. However, a driver in CPMM would not be able to determine those steps if the shipment is detained or describe what happens to the goods when a sample is sent to an inland laboratory for further analysis. Although the 
Figure 7.3: Potential Steps and Data Flow for Corridor Performance Measurement and Monitoring and Time Release Study Complementarity

1. CPMM identifies the locations and activities that are inefficient. Data such as the BCPs are then used as inputs to TRS.

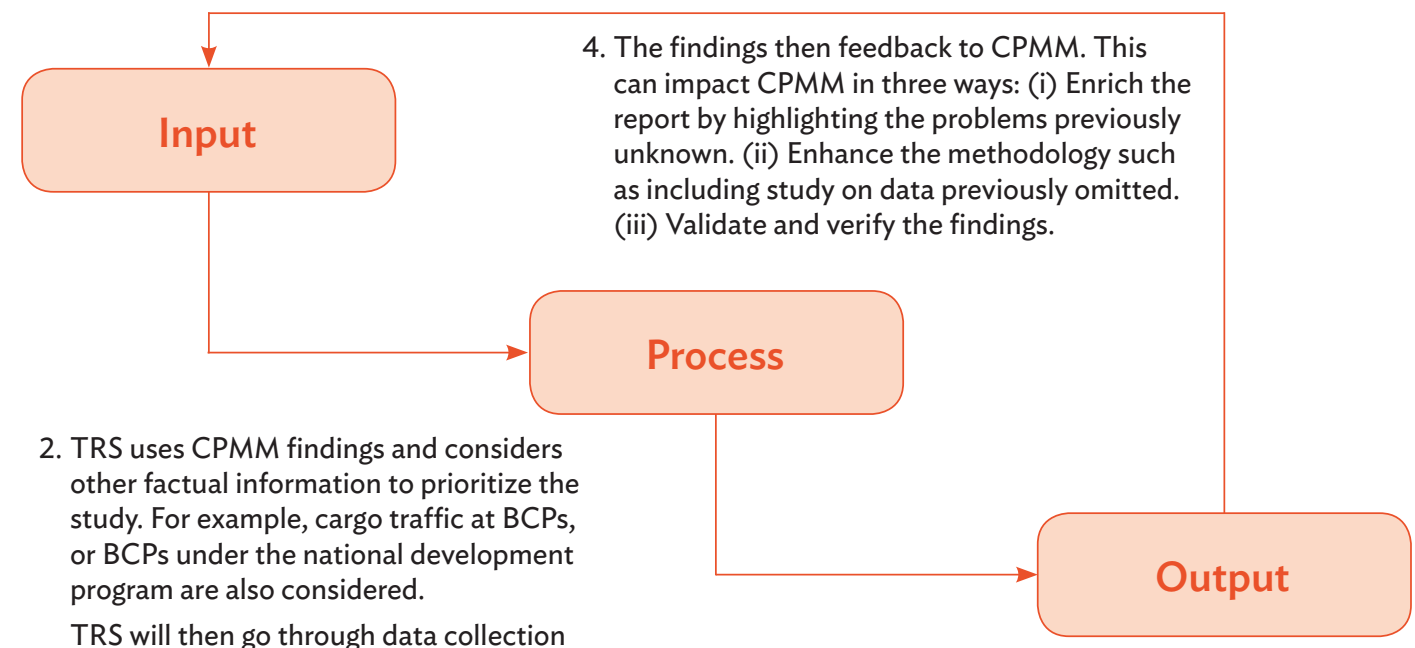
and analysis to further investigate the root causes of inefficiencies.

3. TRS then reports the processes under customs formalities and explain why the inefficiencies occur. This can be published in a report, and disseminated in platforms such as the CAREC Customs Cooperation Committee. Recommendations are also prescribed to deal with the systematic problems "at the border" and "behind the border."

$\mathrm{BCP}=$ border-crossing point, $\mathrm{CAREC}=$ Central Asia Regional Economic Cooperation, $\mathrm{CPMM}=$ Corridor Performance Measurement and Monitoring, TRS = time release study.

Source: Asian Development Bank.

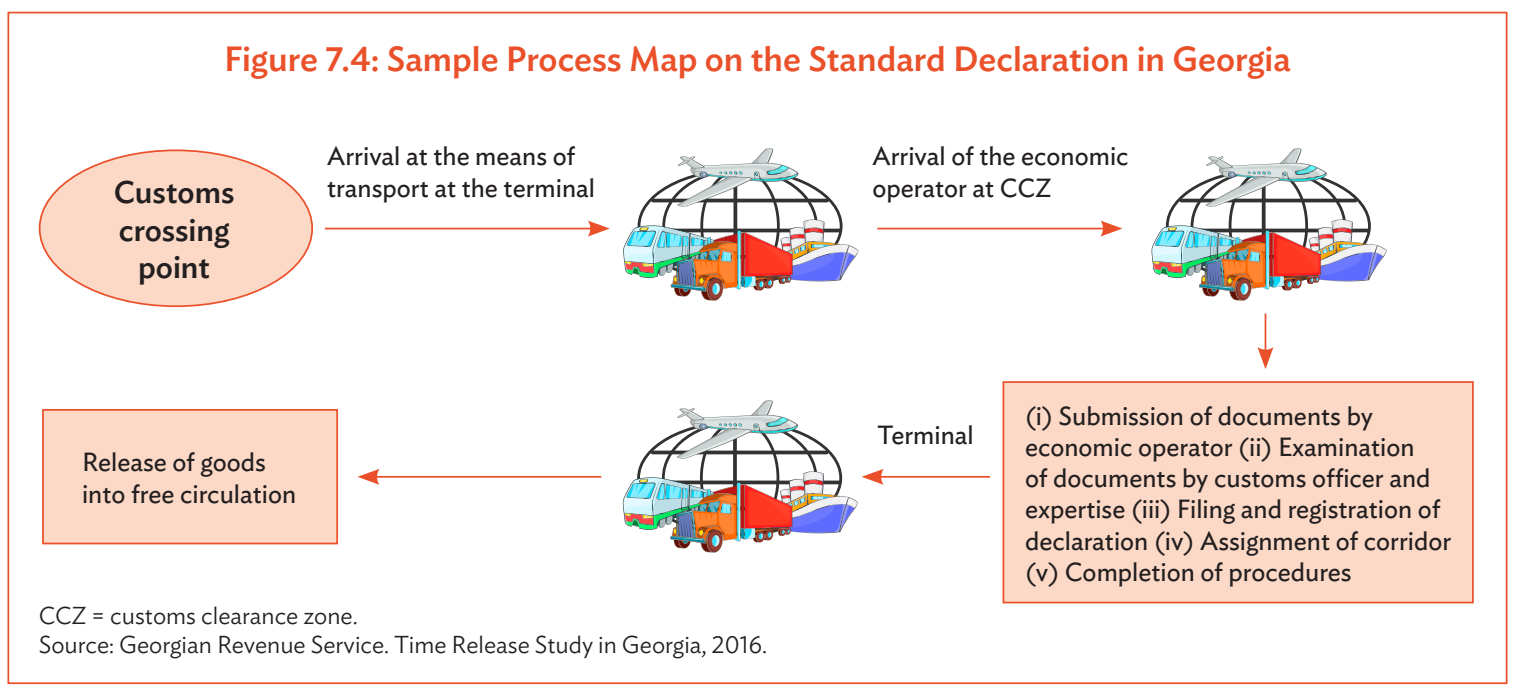


driver personally completes all the activities conducted inside a BCP, there are areas where they appear as a "black box" and cannot be analyzed as the driver is separated from the goods. Thus, TRS is better able to shed light on those "black boxes" for CPMM to assess their impact.

\section{Suggestion 4: Validation and Verification}

Specific border-crossing times measured by CPMM and TRS can act as a control: if there are significant variations at the same $\mathrm{BCP}$, further analysis can be conducted to understand why. Fortunately, both CPMM and TRS findings appear currently to be aligned.

Another potential area of complementarity is the coverage of problems that are scoped outside the existing boundary. For instance, TRS could refer to the CPMM's findings about the long duration of trucks carrying transit goods to Central Asia which exited Tsiteli Khidi, but were not able to enter Krasnyi Most, remaining in no man's land. Should GRS decide to include new BCPs in future TRS activities, such information coming out of the CPMM is useful, could further verify the extent of the problem, and could also suggest joint border customs controls. 


\section{Conclusion}

Corridor Performance Measurement and Monitoring (CPMM) data and analysis for 2019 showed some tangible progress in the trade facilitation indicators (TFIs) for road and railway transport: in road transport, the average border-crossing time remained relatively unchanged, although average costs to clear a border-crossing point (BCP) increased. A reduction was seen in total average cost to move shipments along the CAREC corridors, yet those shipments were traveling at slower average speeds than in 2018. In rail transport, average border-crossing time shortened and cost remained the same, while the total cost to travel a corridor section decreased. Average speed with delay (SWD) and speed without delay (SWOD) were overall both considerably faster in 2019 for rail transport, although average SWOD was slightly slower.

Despite the progress in railway transport, however, much room remains for further improvement and to increase competitiveness and linkage to foreign markets. Based on time and cost metrics alone, railway transport appeared to be a less attractive option for trade: border-crossing time is lengthy, trains traveled at slower speeds, and there is no clear cost advantage for railway over road transport.

Table 8: Road and Rail Transport Trade Facilitation Indicators, 2019

\begin{tabular}{llcc} 
TFI & \multicolumn{1}{c}{ Indicators } & Road & Rail \\
TFI1 & Time to clear a BCP, hours & 12.2 & 20.6 \\
\hline TFI2 & Cost incurred at a BCP, \$ & 161 & 198 \\
\hline TFI3 & Cost incurred to travel a corridor section, \$ & 900 & 820 \\
TFI4 & Speed with delay, $\mathrm{km} / \mathrm{h}$ & 22.6 & 19.0 \\
& Speed without delay, $\mathrm{km} / \mathrm{h}$ & 43.6 & 45.0 \\
\hline
\end{tabular}

$\mathrm{BCP}=$ border-crossing point, $\mathrm{km} / \mathrm{h}=$ kilometer per hour, $\mathrm{TFI}=$ trade facilitation indicator.

Source: Asian Development Bank.

The CPMM Annual Report 2019 also featured a discussion on time release studies (TRSs) and CPMM. Both of these tools are widely used to assess border-crossing performance, and a deeper examination identified where complementary actions could result in beneficial joint application of the tools. Chapter 7 highlighted the experience and results of the Georgian Revenue Service's application of the TRS in 2013 and 2016, against 2019 CPMM findings, and provided recommendations to policy makers keen to adopt both the CPMM and the TRS to improve trade facilitation.

Given the overall results of the 2019 CPMM process, CAREC member countries should focus more on (i) modernizing the transport infrastructure and BCPs; (ii) adopting practical measures and best practices to simplify border crossing; (iii) using risk-based management and programs for selected operators to complete faster and more cost-effective formalities; and (iv) developing bilateral and multilateral agreements and mutual acceptance of standards for transit and trade facilitation, and their sustained implementation. 


\section{Corridor Performance Measurement and Monitoring Methodology}

The Corridor Performance Measurement and Monitoring (CPMM) methodology is based on a time/cost-distance (TCD) framework and involves four major stakeholders: (i) drivers, (ii) CPMM partners and coordinators, (iii) field consultants, and (iv) the Central Asia Regional Economic Cooperation (CAREC) Program trade facilitation unit.

The TCD methodology, developed by the United Nations Economic and Social Commission for Asia and the Pacific, focuses on the time and costs involved in transportation and analyzes transport inefficiency and bottlenecks. It lays out the cost and time components of door-to-door movements of a vehicle along a transport corridor, and tracks delays at borders and other inspection points along the corridor.

Under the CAREC CPMM, coordinators of each CPMM partner every month randomly select drivers transporting cargoes passing through the six CAREC priority corridors to fill up CPMM forms. The coordinators enter data from the drivers' forms into TCD spreadsheets. Each partner association completes about 10-30 TCD forms a month, which are submitted to the field consultants and screened for consistency, accuracy, and completeness.

The TCD data submitted by partner associations is normalized so each TCD sheet can be summed up and analyzed at the subcorridor, corridor, and aggregate level of reporting.

Normalization is done in terms of a 20-ton truck in the case of road transport, or a twenty-foot equivalent unit (TEU) in the case of rail traveling 500 kilometers $(\mathrm{km})$. The number of border-crossing points (BCPs) for subcorridors is also normalized for each 500-km segment.

Normalization of each TCD sheet comprises the following steps:

(i) Each $\mathrm{TCD}$ is split between the non-BCP portion and $\mathrm{BCP}$ portion in case the shipment crossed borders.

(ii) The time and cost figures for the non-BCP portion are normalized to $500 \mathrm{~km}$ by multiplying the ratio of $500 \mathrm{~km}$ by the actual distance traveled.

(iii) The time and cost figures for the $\mathrm{BCP}$ portion are normalized based on the ratio of a predetermined number of BCPs for each $500-\mathrm{km}$ segment over the actual number of BCPs crossed.

(iv) The TCD is reconstituted by combining the normalized non-BCP portion and the normalized BCP portion.

To measure the average speed and cost of transport for trade, the cargo tonnage or number of TEU containers is used as weights (normalized at 20 tons) in calculating the weighted averages of speed and cost for subcorridors, corridors, and for the data overall, based on normalized TCD samples.

The detailed CPMM flowchart is in Figure A1.

CPMM partners are national transport carriers and forwarders selected to work with the CAREC trade facilitation unit in implementing the CPMM. A specific person is assigned by each partner to receive training on the CPMM mechanism, train the drivers, customize the drivers' form, and enter the data into a customized spreadsheet. 


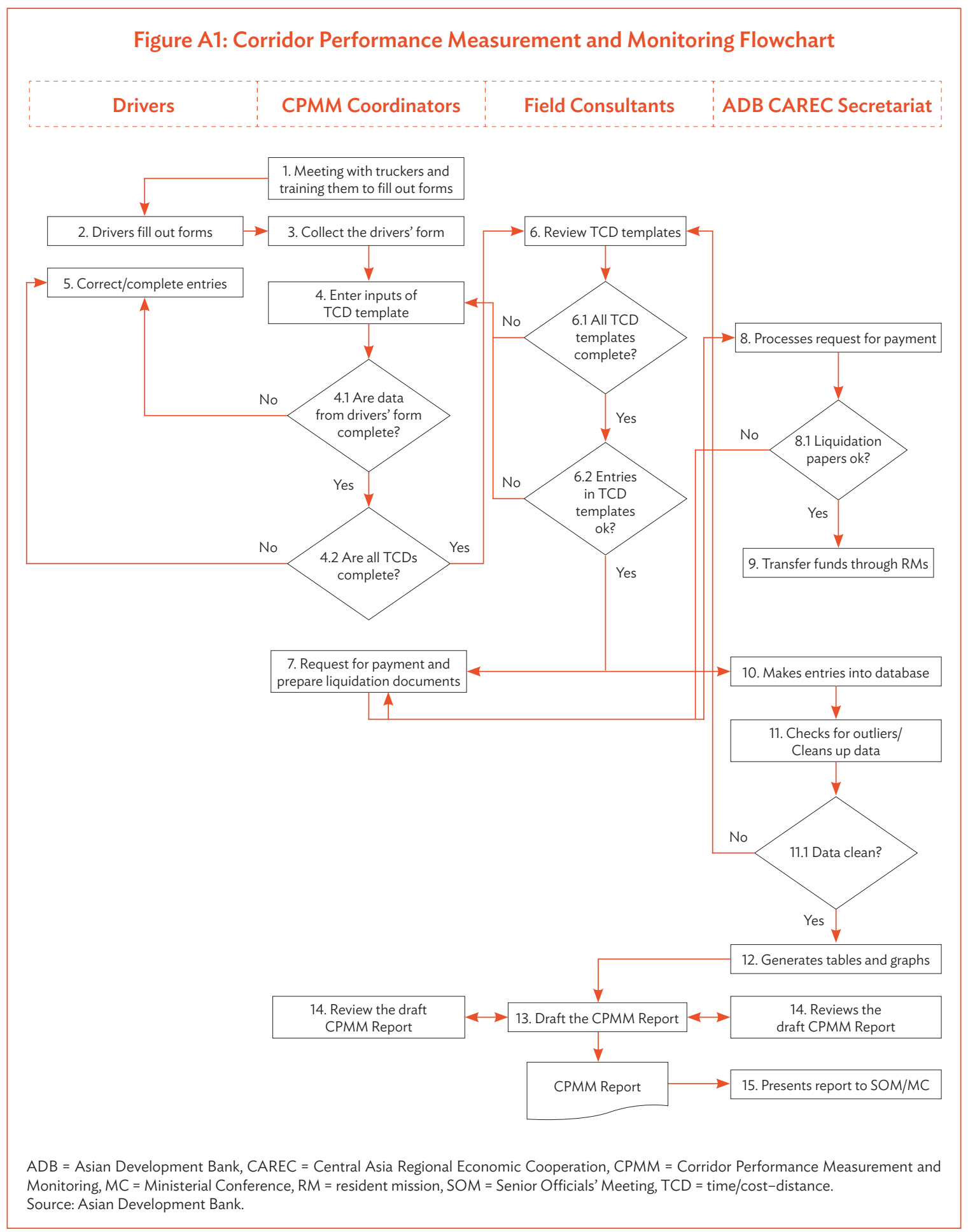




\section{National Association Drivers}

To ensure accuracy of CPMM data analysis, raw data should be collected as close to the source as possible. Drivers are asked to record how long (time) or how much (cost) it takes them to move from origin to destination. The drivers use a country-specific driver's form to record and submit data to the CPMM partners.

\section{Field Consultants}

Two international field consultants work with the CAREC trade facilitation team to develop the CPMM methodology, and travel to the CAREC countries to standardize implementation. They also analyze the aggregated data and draft CPMM quarterly and annual reports.

\section{CAREC Trade Facilitation Unit}

Based in the headquarters of the Asian Development Bank (located in Manila, Philippines), the CAREC trade facilitation unit is responsible for collecting and aggregating all completed CPMM spreadsheets. Using specialized statistical software, the team constructs the charts and tables for analysis by the field consultants, and assists in CPMM report preparation. 


\section{Partner Associations}

Central Asia Regional Economic Cooperation (CAREC) Corridor Performance Measurement and Monitoring (CPMM) partners are national carrier and forwarder associations already established in CAREC member countries and are essential to the success of the CPMM mechanism. Trained to gather CPMM raw data, their key responsibilities include the following:

(i) act as the local focal point to collaborate with the Asian Development Bank (ADB) CAREC trade facilitation team in conducting the CPMM annual exercise;

(ii) organize and train drivers to use customized drivers' forms for data collection;

(iii) review completed drivers' forms to ensure data completeness and correctness;

(iv) input raw data from drivers' forms into the CPMM spreadsheets; and

(v) submit completed CPMM files to CAREC.

Table A2: 2019 Corridor Performance Measurement and Monitoring Partner Associations

\begin{tabular}{|c|c|c|c|c|}
\hline & Country & Association & Abbreviation & $\begin{array}{c}\text { Shipment } \\
\text { Data } \\
\text { Collected }\end{array}$ \\
\hline 1 & Afghanistan & Association of Afghanistan Freight Forwarding Companies & AAFFCO & 360 \\
\hline 2 & \multirow{3}{*}{$\begin{array}{l}\text { China, } \\
\text { People's } \\
\text { Republic of }\end{array}$} & Chongqing International Freight Forwarders Association & CQIFA & 300 \\
\hline 3 & & Inner Mongolia Autonomous Region Logistics Association & IMARLA & 237 \\
\hline 4 & & Xinjiang Uygur Autonomous Region Logistics Association & XULA & 420 \\
\hline 5 & Georgia & Georgia International Road Carriers Association & GIRCA & 70 \\
\hline 6 & Kazakhstan & Association of National Freight Forwarders of the Republic of Kazakhstan & KFFA & 120 \\
\hline 7 & Kyrgyz Republic & Freight Operators Association & FOA & 120 \\
\hline 8 & \multirow[t]{3}{*}{ Mongolia } & Federation of Mongolian Freight Forwarders & FMFF & 180 \\
\hline 9 & & Mongolia Chamber of Commerce and Industry & $\mathrm{MNCCl}$ & 60 \\
\hline 10 & & National Road Transport Association of Mongolia & NARTAM & 240 \\
\hline 11 & Pakistan & Pakistan International Freight Forwarders Association & PIFFA & 240 \\
\hline 12 & \multirow[t]{2}{*}{ Tajikistan } & Association of Road Transport Operators of Republic of Tajikistan & ABBAT & 120 \\
\hline 13 & & Association of International Automobile Transport of Tajikistan & AIATT & 26 \\
\hline 14 & \multirow[t]{3}{*}{ Uzbekistan } & Association for Development of Business Logistics & $A D B L$ & 360 \\
\hline 15 & & Association of International Road Carriers of Uzbekistan & AIRCUZ & 120 \\
\hline & & & TOTAL & 2,973 \\
\hline
\end{tabular}

Source: Asian Development Bank. 


\section{APPENDIX 3 \\ Trade Facilitation Indicators}

Recognizing the pivotal roles of trade facilitation and transport connectivity in the economic growth of the Central Asia Regional Economic Cooperation (CAREC) region, member countries jointly developed and endorsed the CAREC Transport and Trade Facilitation Strategy (TTFS) in 2007. The TTFS had an integrated approach that centered on the development of six priority CAREC corridors through transport infrastructure investments and trade facilitation initiatives. It also mandated the monitoring and periodic measurement of the performance of the six transport corridors to

(i) identify the causes of delays and unnecessary costs along the links and nodes of each CAREC corridor, including border-crossing points (BCPs) and intermediate stops;

(ii) help authorities determine how to address the identified bottlenecks; and

(iii) assess the impact of regional cooperation initiatives.

In 2008, ADB developed the CAREC Corridor Performance Measurement and Monitoring (CPMM) methodology that offers an accurate and evidence-based foundation for policies aimed at addressing these objectives. The current CPMM methodology is a result of modifications in the original UNESCAP time/cost-distance (TCD) methodology that optimized its ability to measure and monitor effectively the border crossing and corridor performance of CAREC corridors over time. The methodology offers an extensive picture of the time and cost dimensions of transport and trade facilitation, particularly with regard to border crossings and other impediments along a transit corridor. Aside from time and cost, derived measures such as speed can be used to assess traffic density and road quality. With these factors, several measures and indicators can be developed for the monitoring of border crossing and customs service efficiency, as well as road and rail infrastructure performance along corridors. When the corridors are monitored regularly, policy makers can easily pinpoint areas that need improvement and financial investment.

With data from TCD-format questionnaires, the following four trade facilitation indicators (TFIs) are monitored regularly to enable assessment of improvements made in the CAREC corridors. However, unlike other indicators, TFls are more difficult to quantify as they depend on a variety of factors such as (i) the quality and availability of physical infrastructure, (ii) national policies and regulations for transit and trade, (iii) border-crossing procedures, and (iv) the degree of harmonization among countries. Figure A3 illustrates the scope and extent measured in each indicator.

- TFI1: Time taken to clear a BCP. This TFI refers to the average length of time (hours) it takes to move cargo across a border from entry to exit of a BCP. The entry and exit points are typically primary control centers where customs, immigration, and quarantine are handled. Along with the standard clearance formalities, this measurement includes waiting time, unloading or loading time, and time taken to change rail gauges, among other indicators. The intent is to capture both the complexity and the inefficiencies inherent in the border-crossing process.

- TFI2: Costs incurred at a BCP. This is the average total cost, in United States dollars (\$), of moving cargo across a border from entry to exit of a BCP. Both official and unofficial payments are included. This indicator assumes 20 tons of cargo, so the average costs across various samples are comparable. 
Figure A3: Measuring the Trade Facilitation Indicators

\section{Road Transport}

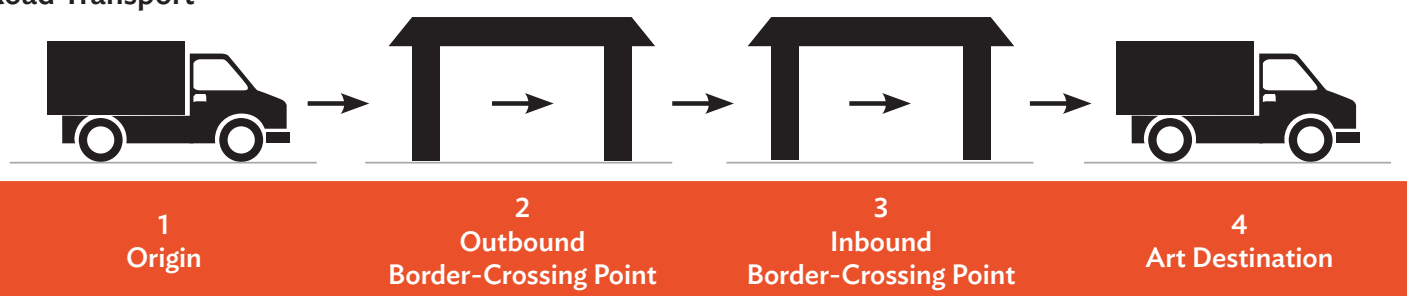

CPMM starts measurement when The truck driver then waits in line The truck driver again waits in line The process of exiting a country goods are loaded at the origin. until his turn to enter the BCP. until his turn to enter the $\mathrm{BCP}$ and entering another is repeated

Oftentimes, a truck stops at When the truck is admitted into intermediate nodes (for activities the BCP, the driver has to undergo such as traffic police checkpoints) a series of border activities. For before reaching the outbound BCPs that offer single window $B C P$ of the country of departure. services, the process could be faster. Any transloading (transfer of goods between trucks) is also done here under customs' supervision.

Upon completion of bordercrossing procedures, the truck exits the BCP, proceeds through the "no man's land" until it arrives at the inbound $\mathrm{BCP}$ of the adjacent country.

TFI3 measures the total transport rate from origin to destination, including cost of activities at BCPs and intermediate stops, per $500 \mathrm{~km}$ and per payload of 20 tons.

SWOD is derived from the speed of the truck while it is in transit.

TFI4 is derived by adding the time spent on BCPs and intermediate stops.

\section{Rail Transport}

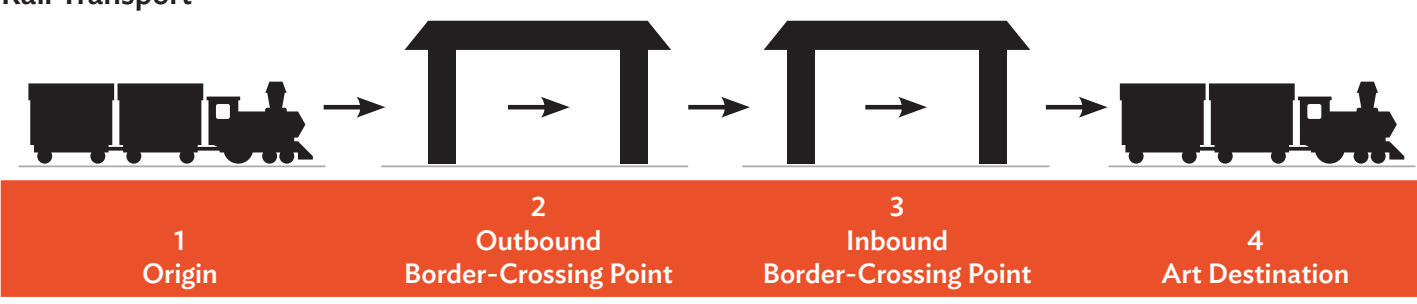

CPMM tracks the movement of a At the outbound $\mathrm{BCP}$, the specific wagon or a container, and shipment undergoes customs not the entire train, as reported formalities, as well as other rail by its partner international freight operations, to ensure the safety forwarders.

CPMM starts measurement when of the train and goods. After completion, the train is released goods are loaded at the origin. the inbound BCP of the adjacent country. At times, trains Inside the inbound $\mathrm{BCP}$, the ( der activities. Upon completion, the truck exits the $\mathrm{BCP}$ and proceeds with its

TFI1 and TFI 2 measure the duration and cost, respectively, until the shipment reaches its destination country.

At the final destination, goods or containers are offloaded. In general, CPMM does not include in its measurement customs clearance and collection by the consignee.

the activities upon reaching and until exiting each BCP.

Oftentimes, a train stops at intermediate nodes (for activities are withheld if the inbound $B C P$ is

At the inbound BCP, the shipment The process of exiting a country undergoes another set of customs and entering another is repeated formalities and necessary rail until the shipment reaches its operations. destination country.

TF1 and TFI2 measure the At the final destination, goods duration and cost, respectively, or containers are offloaded. In of the activities upon reaching general, CPMM does not include congested.

in its measurement customs clearance and collection by the consignee.

such as classification and

marshaling) before reaching the outbound BCP of the country of departure.

TFI3 measures the total rail freight rate from origin to destination, including cost of activities at BCPs and intermediate stops, per $500 \mathrm{~km}$ and per payload of 20 tons.

SWOD is derived from the speed of the train while it is in transit.

TFI4 is derived by adding the time spent on BCPs and intermediate stops.

$\mathrm{BCP}=$ border-crossing point, $\mathrm{CPMM}=$ Corridor Performance Measurement and Monitoring, $\mathrm{km}=$ kilometer, $\mathrm{SWOD}=$ speed without delay, $\mathrm{TFI}=$ trade facilitation indicator. Source: Asian Development Bank. 
The CPMM mechanism also analyzes unofficial payments: these are defined as a sum paid on top of that officially recognized by law, with the aim of gaining a favor preferential treatment in return. No official receipt is given. Tracking an unofficial payment is inherently difficult due to the opaque nature of the transaction.

- TFI3: Costs incurred while traveling along a corridor section. This is the average total costs, in $\$$, incurred for a unit of cargo traveling along a corridor section within a country or across borders. A "unit of cargo" refers to a cargo truck or train with 20 tons of goods. A "corridor section" is defined as a stretch of road 500-kilometers $(\mathrm{km})$ long. Both official and unofficial payments are included.

This indicator is the sum of border-crossing cost and vehicle transport cost. Vehicle transport cost is defined as the variable cost component for a shipment: including remuneration for the driver during the shipment, sustenance cost (food and drink, accommodation), fuel cost, parking fees, and minor repairs.

The cost components must be specific to the shipment. Nonspecific cost items that are overheads or annual fees such as vehicle tax, insurance, depreciation, and one-time vehicle overhaul are not included in the calculation of vehicle transport cost. In general, the main drivers for this cost are driver remuneration and fuel cost.

Many factors can affect vehicle transport cost and, thus, influence the total transport cost. Factors such as distance, weight of cargo, quality of transport infrastructure, number of BCPs, oil price, foreign currency exchange rate, time of year of travel, empty backhaul, market competition, and new legislation can exert a sizable influence on it. All things being equal, vehicle transport cost will be primarily affected by the distance and cargo weight, as this is the basis for the carrier's quote of the shipment price. In practice, due to data collection constraints, transport cost figures reported in CPMM refer to transport rates for trucks, or railway tariffs for trains. "Transport cost" is viewed from the perspective of the shipper or receiver. It represents the market rate paid to move the cargo-not the carrier's cost of providing the service.

To standardize transport cost, the CPMM adopts $500 \mathrm{~km}$ as a unit of distance, and 20 tons as a unit of weight. This standardized unit enables comparisons to be made between road shipments across different corridors with varying distance and weight.

- TFI4: Speed of travel along a corridor section. This is the average speed, in kilometers per hour $(\mathrm{km} / \mathrm{h})$, at which a unit of cargo travels along a corridor section within a country or across borders. Again, a "unit of cargo" refers to a cargo truck or train with 20 tons of goods, and a "corridor section" refers to a stretch of road 500-km long. Speed is calculated by dividing the total distance traveled by the duration of travel. Distance and time measurements include border crossings.

The CPMM uses two measures of speed: speed without delay (SWOD) and speed with delay (SWD). SWOD is the ratio of the distance traveled to the time spent by a vehicle in motion between origin and destination (actual traveling time). SWD is the ratio of distance traveled to the total time spent on the journey, including the time the vehicle was in motion and the time it was stationary. Under the CPMM, all activities that delay (customs controls, inspections, loading and unloading, and police checkpoints, among others) are recorded by drivers. SWOD represents a measure of the condition of physical infrastructure (such as roads and railways), while SWD is an indicator of the efficiency of BCPs along the corridors. 


\section{Statistical Derivation of the Trade Facilitation Indicators}

TFI1: Time taken to clear border-crossing point (hour). This indicator highlights bottlenecks at BCPs, which typically involve lengthy border-crossing procedures and serious delays. Each component activity can be further examined to pinpoint the principal cause of delays.

\begin{tabular}{|c|c|c|}
\hline & Formula & Remarks \\
\hline Formula, per TCD calculation & $\begin{array}{l}\operatorname{TFI}_{i}=\sum_{j=1}^{a} t_{j} \\
t_{j}=\text { time spent on each activity } j \\
j=1,2, \ldots, a a=\text { number of activities in } \\
\text { each border crossing } \\
i=1,2, \ldots, n n=\text { number of } T C D s\end{array}$ & $\begin{array}{l}\text { The sum is taken from all of the } \\
\text { activities carried out in each border } \\
\text { crossing. However, for comparison, } \\
\text { activities recorded under "others" are } \\
\text { not included. }\end{array}$ \\
\hline $\begin{array}{l}\text { Aggregation, average value per corridor } \\
\text { and per mode of transport }\end{array}$ & $\begin{array}{l}\sum_{i=1}^{11} \text { TFII }_{i} \\
n=\text { number of TCDs qualifying a given } \\
\text { filter (per mode/per corridor) } \\
i=1,2, . ., \mathrm{n} n=\text { number of TCDs }\end{array}$ & $\begin{array}{l}\text { The computation of the average } \\
\text { is straightforward; no weights are } \\
\text { necessary. }\end{array}$ \\
\hline
\end{tabular}

TFI2: Costs incurred at a BCP (\$). This indicator highlights BCPs that have relatively expensive bordercrossing procedures, including unofficial payments. Each component activity can be further examined to pinpoint the drivers of cost.

\begin{tabular}{|c|c|c|}
\hline & Formula & Remarks \\
\hline Formula, per TCD calculation & $\begin{array}{l}\text { TFI } 2_{i}=\sum_{j=1}^{a} c_{j} \\
c_{j}=\text { cost incurred on each activity } j \\
j=1,2, \ldots, a a=\text { number of activities in } \\
\text { each border crossing } \\
i=1,2, \ldots, n n=\text { number of TCDs }\end{array}$ & $\begin{array}{l}\text { The sum is taken from all of the } \\
\text { activities carried out in each border } \\
\text { crossing. However, for comparison, } \\
\text { activities recorded under "others" are } \\
\text { not included. }\end{array}$ \\
\hline $\begin{array}{l}\text { Aggregation, average value per corridor } \\
\text { and per mode of transport }\end{array}$ & $\begin{array}{l}\sum_{i=1}^{n} T F I 2_{i} \\
n=\text { number of TCDs qualifying a given } \\
\text { filter (per mode/per corridor) } \\
i=1,2, \ldots, n n=\text { number of } T C D s\end{array}$ & $\begin{array}{l}\text { The computation of the average } \\
\text { is straightforward; no weights } \\
\text { are necessary. }\end{array}$ \\
\hline
\end{tabular}


TFI3: Costs incurred traveling along a corridor section (\$). This indicator provides an insight into the cost structure of a corridor and how it compares with those of other corridors. By examining each component, measures can be developed to minimize transit cost.

\begin{tabular}{|c|c|c|}
\hline & Formula & Remarks \\
\hline Formula, per TCD calculation & $\begin{array}{l}\text { TFI } 3_{1}=v_{i}+b_{1}+s_{1} \\
v_{i}=\text { cost incurred during transit, per } \\
500 \mathrm{~km} \\
b_{i}=\text { cost incurred during border crossing, } \\
\text { per } 500 \mathrm{~km} \\
s_{i}=\text { cost incurred during intermediate } \\
\text { stops, per } 500 \mathrm{~km} \\
i=1,2, . ., \mathrm{n} \mathrm{n}=\text { number of TCDs }\end{array}$ & $\begin{array}{l}\text { The normalized cost incurred, per } \\
500 \mathrm{~km} \text { and per } 20 \text { tons of cargo (road) } \\
\text { or one } 20 \text {-foot equivalent unit (rail), in } \\
\text { traveling a corridor section is the sum } \\
\text { of normalized vehicle-operating or rail } \\
\text { wagon-operating cost during transit and } \\
\text { normalized cost during intermediate } \\
\text { stops and border crossings. }\end{array}$ \\
\hline $\begin{array}{l}\text { Aggregation, average value per corridor } \\
\text { and per mode of transport }\end{array}$ & $\begin{array}{l}\sum_{i=1}^{n} \text { TFI } 3_{i} \\
n=\text { number of TCDs qualifying a given } \\
\text { filter (per mode/per corridor) } \\
i=1,2, . ., n n=\text { number of TCDs }\end{array}$ & $\begin{array}{l}\text { The computation of the average } \\
\text { is straightforward; no weights } \\
\text { are necessary. }\end{array}$ \\
\hline
\end{tabular}

TFI4: Speed of travel along a corridor section $(\mathrm{km} / \mathrm{h})$. Speed indicators provide insights into the level of infrastructure development of CAREC corridors by providing information on the speeds that cargo trucks and trains can attain while traversing specific corridor sections. Under the CPMM, speed is measured by two indicators: SWOD and SWD.

Another factor to consider is the weighting of the observations in the aggregation. As the computed speed represents the transport of the truck or train, speed should be weighted by the tonnage of cargo to represent the weighted average of speed of the cargo itself.

SWOD, in $\mathrm{km} / \mathrm{h}$. This metric considers traveling speed only, i.e., when the delivery truck is moving on the road, or when the train is moving on the tracks. When the vehicle or train is stationary, the time is not counted.

\begin{tabular}{|c|c|c|}
\hline & Formula & Remarks \\
\hline Formula, per TCD calculation & $\begin{array}{l}S W O D_{i}=\frac{D_{i}}{T_{i}} \\
D=\text { distance traveled from previous stop } \\
T=\text { duration of travel } \\
i=1,2, \ldots, n n=\text { number of } T C D s\end{array}$ & \\
\hline $\begin{array}{l}\text { Aggregation, average value per corridor } \\
\text { and per mode of transport }\end{array}$ & $\begin{array}{l}\sum_{i=1}^{n}\left(w_{1}\right) S W O D_{i} \\
n=\text { number of TCDs qualifying a given } \\
\text { filter (per mode/per corridor) } \\
W_{1}=\frac{4}{\sum_{i=1}^{n} C_{1}} \\
i=1,2, . ., n n=\text { number of TCDs }\end{array}$ & $\begin{array}{l}\text { Since computation is per TCD } \\
\text { calculation, each TCD is normalized } \\
\text { and treated independently. Also, speed } \\
\text { average is not weighted by duration of } \\
\text { travel (a mathematical computation), } \\
\text { and equal weights are given to each } \\
\text { record. This method does not give } \\
\text { more importance to longer trips than } \\
\text { to shorter ones. But records should be } \\
\text { weighted by tonnage to measure the } \\
\text { average speed of a unit of cargo, and not } \\
\text { of the trips. }\end{array}$ \\
\hline
\end{tabular}


SWD, in $\mathrm{km} / \mathrm{h}$. This application of SWD considers the total time taken for the entire journey, including stoppage time for various reasons.

\begin{tabular}{|c|c|c|}
\hline & Formula & Remarks \\
\hline \multirow[t]{5}{*}{ Formula, per TCD leg } & $S W D_{i}=\frac{D_{i}}{T_{i}+A}$ & \\
\hline & $D=$ distance traveled from previous stop & \\
\hline & $T=$ duration of travel & \\
\hline & $\begin{array}{l}A=\text { duration of activities (BCP and } \\
\text { non- } B C P \text { ) }\end{array}$ & \\
\hline & $i=1,2, \ldots, \mathrm{n} n=$ number of TCDs & \\
\hline $\begin{array}{l}\text { Aggregation, average value per corridor } \\
\text { and per mode of transport }\end{array}$ & $\begin{array}{l}\sum_{i=1}^{\prime \prime}\left(w_{1}\right) S W D_{i} \\
n=\text { number of TCDs qualifying a given } \\
\text { filter (per mode/per corridor) } \\
W_{1}=\frac{4}{\sum_{i=1}^{n} C_{i}} \\
i=1,2, . ., n n=\text { number of TCDs }\end{array}$ & $\begin{array}{l}\text { Since computation is per TCD } \\
\text { calculation, each TCD is normalized } \\
\text { and treated independently. Also, speed } \\
\text { average is not weighted by duration of } \\
\text { travel (a mathematical computation), } \\
\text { and equal weights are given to each } \\
\text { record. This method does not give } \\
\text { more importance to longer trips than } \\
\text { to shorter ones. But records should be } \\
\text { weighted by tonnage to measure the } \\
\text { average speed of a unit of cargo, and not } \\
\text { of the trips. }\end{array}$ \\
\hline
\end{tabular}




\section{Border-Crossing Activities}

Under the Corridor Performance Measuring and Monitoring (CPMM) mechanism, time spent and payments made (official and unofficial) at each stop are recorded by activity. The list of activities encompasses all anticipated checks and procedures, both at border-crossing points (BCPs) and at intermediate stops along the transit corridor. However, as the CPMM focuses on BCPs, the list comprises mainly customs procedures and inspections during border crossings.

\section{Road Transport}

(i) Border security and control. Security personnel (i.e., the police or military) inspecting goods and checking documents at BCPs. Also includes payment of fees that may be official or unofficial.

(ii) Customs clearance. Customs personnel inspecting documents and goods entering or exiting a country. Similar activities are compiling customs forms and paying fees.

(iii) Health or quarantine inspection. Health authorities checking a person for the presence of malignant or contagious disease. Also includes filling up health or quarantine forms, paying fees, and others.

(iv) Phytosanitary inspection. Agriculture authorities inspecting cargo for possible presence of harmful pests and plant diseases. Similar activities include filling up phytosanitary forms and paying fees.

(v) Veterinary inspection. Veterinary authorities inspecting cargo for the possible presence of infectious animal diseases and regulating the flow of animals and animal products to a location. Similar activities are filling up veterinary forms and paying fees.

(vi) Visa or immigration. Immigration authorities checking visas, and other required activities to apply for a visa to enter and exit the country when the driver has no valid visa. Also includes filling up immigration or visa forms and paying fees.

(vii) Traffic inspection. Inspection by the Traffic Inspectorate or State Traffic Safety Inspectorate. GAI means Gosudarstvennya Avtomobilnaya Inspektsyya.

(viii) Police checkpoint or stop. Traffic police covering roadblocks or checkpoints along a road that also requires payment to proceed.

(ix) Transport inspection. Checking the Certificate of Approval or Conformity for the vehicles. Road passes are also checked.

(x) Weight and standard inspection. Checking the dimensions and weight of the vehicle with cargo, including queuing, payment of fees, and others.

(xi) Vehicle registration. Registration of vehicle, and/or payment of applicable road use taxes and/or transit fees.

(xii) Emergency repair. Ad hoc repairs on vehicles that may be due to a tire blow-out, broken axle, and other reasons, generally because of bad road conditions. This is different from planned maintenance.

(xiii) Escort or convoy. A convoy is a row of vehicles that moves together. The vehicles are accompanied by escorts, who can be customs officials or traffic police to ensure that the cargoes reach their destination. 
(xiv) Loading and/or unloading. Loading goods at the point of origin or loading and unloading at intermediate stops to deconsolidate cargo (i.e., transfer goods to another vehicle), or unloading upon delivery at the destination.

(xv) Road toll. Fees payable when drivers use a special section of roads or highways that are intended to shorten the travel time.

(xvi) Waiting or queuing. Waiting in lines at BCPs. Note that this activity does not include other activities, such as waiting in line to fill up or submit customs clearance documents, which is recorded as part of customs clearance.

\section{Rail Transport}

(i) Load cargoes. The movement of goods from storage or warehouse to the train. If the goods are moved to a temporary storage, such as the staging area or loading docks before relocating to the train, then only the time from the staging area or loading docks to the train is considered.

(ii) Unload cargoes. The movement of goods from the train to storage or warehouse. If the goods are moved to a temporary storage, such as the staging area or loading docks before relocating to the warehouse, then consider only the time from the train to the staging area or loading docks.

(iii) Fix cargo shift. This refers to the securing of cargoes inside the container or wagon. When items are stuffed into containers, workers may "choke" or secure the cargoes to ensure they stay in position during transit. For instance, automobiles also need additional securing. This is to ensure cargoes stay in position during transit. Normally, this is a problem related to manufactured products transported on pallets or in cartons and may not apply to bulk commodities.

(iv) Remove excess cargo. The movement of excess goods to comply with the weight requirement. This does not include inspection time. This activity only starts when the officer declares an "overweight" and orders a removal, and ends when the excess goods are relocated from the train.

(v) Transload at gauge change point. This only happens at the People's Republic of China (PRC) border or Polish border with a Commonwealth of Independent States (CIS) country. As the CIS uses 1,520 millimeter ( $\mathrm{mm}$ ) gauge, while non-CIS countries use 1,435 $\mathrm{mm}$ gauge, the cargoes need to be transloaded. This is done by changing the wheel sets or relocating the goods using forklifts.

(vi) Pickup and deliver wagons. The movement of loaded containers and wagons between terminals to the consignee's premises.

(vii) Replace or repair inoperable wagon. This applies only if one or more train wagons is found to need service because they are significantly damaged and cannot be addressed by emergency repair. The action includes the movement from the tracks to the servicing centers, as well as the actual repair of the wagon in the servicing center.

(viii) Emergency repair. Servicing of wagons on the tracks in the marshaling yard, without removing the wagon from the train. In this case the wagon is salvageable, in contrast to the more severe problem under the previous activity.

(ix) Trains classification. The internal regroup of goods, platform, wagons, and containers to form a new train. This is needed as goods are bound for different destinations and leave at different schedules. Normally, this happens at major rail terminals.

(x) Fix document errors. This applies to a special situation when there are errors on the documents (freight bill, cargo manifest, packing list, and others). It does not include normal processing time and starts only when an error is found, and action is taken to correct the error. This activity ends when the authorities confirm the error is corrected. At borders, this correction may require substantial effort and many days to complete. 
(xi) Reissue transit documents. This typically applies to PRC rail shipments to CIS countries. Not all PRC railways stations can handle international shipments, but there are occasions when loading and/or unloading is necessary in such domestic stations. Thus, a domestic document is used for movement of cargo from this station to the international terminal (such as Urumqi in the Xinjiang Uygur Autonomous Region), where another set of international documents is used. This is when the data are manually rewritten or translated.

(xii) Customs inspection. The customs officer inspecting to assess compliance with the customs code. The customs officers also check for any dutiable goods, forbidden items, or dangerous goods.

(xiii) Technical inspection. Engineers or technicians inspecting to ascertain cargo security and safety, as well as the condition of the train and its equipment.

(xiv) Commercial inspection. An activity undertaken by a regulatory agency to affirm the quality of the shipment or to ensure certain restricted material (dual use) is not exported.

(xv) Sanitary and phytosanitary control. The phytosanitary team regularly checking the train's sanitation standards, as well as the acceptability of goods, such as agriculture, food, meat, and consumable products. This action also covers health issues, such as health certificates of the staff onboard the train.

(xvi) Waiting due to various reasons. An activity undertaken by a regulatory agency to affirm the quality of the shipment or to ensure certain restricted material (dual use) is not exported. 


\section{APPENDIX 5 \\ Central Asia Regional Economic Cooperation Border-Crossing Points}

The endorsement and implementation of the Central Asia Regional Economic Cooperation (CAREC) Transport and Trade Facilitation Strategy in 2007 included the identification of six priority CAREC corridors where transport infrastructure investments and trade facilitation initiatives would be focused. The CAREC Corridor Performance Measuring and Monitoring (CPMM) mandate to identify causes of delays and unnecessary costs along the links and nodes of each CAREC corridor, including bordercrossing points (BCPs) and intermediate stops emphasizes monitoring $\mathrm{BCPs}$ where shipments undergo several transactions and procedures related to transborder trade.

Table A5 lists key BCP pairs for each side of the border.

Table A5: CAREC Corridor Border-Crossing Points

\begin{tabular}{|c|c|c|c|c|c|}
\hline No. & Corridor & & BCP1 & & $\mathrm{BCP} 2$ \\
\hline 1 & $1 \mathrm{a}, 2 \mathrm{c}$ & PRC & Alashankou & KAZ & Dostyk \\
\hline 2 & $1 \mathrm{a}, 1 \mathrm{c}$ & KAZ & Kairak & RUS & Troitsk \\
\hline 3 & $1 b$ & PRC & Khorgos & KAZ & Korgas \\
\hline 4 & $1 b, 6 b, 6 c$ & KAZ & Zhaisan & RUS & Kos Aral/Novomarkovka (Sagarchin) \\
\hline 5 & $1 c$ & PRC & Torugart/Topa & KGZ & Torugart \\
\hline 6 & $1 c, 3 b$ & KAZ & Merke & KGZ & Chaldovar \\
\hline 7 & $2 a, 2 b, 2 d, 5 a, 5 c$ & PRC & Yierkeshitan & KGZ & Irkeshtam \\
\hline 8 & $2 a, 2 b$ & KGZ & Kara-Suu (Dostuk) & UZB & Kara-Suu/Savay (Dustlik) \\
\hline 9 & $2 a, 2 b$ & TAJ & Kanibadam & UZB & Kokland \\
\hline 10 & $2 a, 2 b$ & TAJ & $\mathrm{Nau}$ & UZB & Bekabad \\
\hline 11 & $2 a, 6 a$ & KAZ & Beyneu (rail)/Tazhen (road) & UZB & Karakalpakstan (Daut-Ata) \\
\hline 12 & $2 a, 2 c$ & AZE & Baku & KAZ & Aktau \\
\hline 13 & $2 a, 2 b, 2 c$ & AZE & Red Bridge (road)-Beyuk Kesik (rail) & GEO & Red Bridge (road)-Gabdabani (rail) \\
\hline 14 & $2 b, 3 a$ & UZB & Alat & TKM & Farap \\
\hline 15 & $2 b$ & AZE & Baku & TKM & Turkmenbashi \\
\hline 16 & $2 d, 3 b, 5 a, 5 c$ & KGZ & Karamyk & TAJ & Karamyk \\
\hline 17 & $2 d, 5 a, 5 c, 6 c$ & AFG & Shirkhan Bandar & TAJ & Panji Poyon/Nizhni Pianj \\
\hline 18 & $3 a, 3 b$ & KGZ & Aul & RUS & Veseloyarsk \\
\hline 19 & $3 a, 6 b, 6 c$ & KAZ & Zhibek Zholy-Saryagash/Yallama & UZB & Gisht Kuprik-Keles \\
\hline 20 & $3 a$ & TKM & Sarahs & IRN & Sarakhs \\
\hline 21 & $3 b$ & TAJ & Pakhtaabad & UZB & Saryasia \\
\hline 22 & $3 a, 6 a, 6 b$ & AFG & Hairatan & UZB & Termez/Airatom \\
\hline 23 & $3 b, 6 b, 6 d$ & AFG & Islam Qala & IRN & Dogharoun \\
\hline 24 & $4 a$ & MON & Ulaanbaishint/Tsagaanur & RUS & Tashanta \\
\hline 25 & $4 a$ & PRC & Takeshikent & MON & Yarant \\
\hline 26 & $4 b, 4 c$ & MON & Sukhbaatar & RUS & Naushki \\
\hline 27 & $4 b$ & PRC & Erenhot & MON & Zamiin-Uud \\
\hline 28 & $6 a, 6 d$ & KAZ & Kurmangazy (road)/Ganyushking (rail) & RUS & Krasnyi Yar (road)/Aksaraskaya (rail) \\
\hline 29 & $6 c$ & TAJ & Istaravshan & UZB & Khavast \\
\hline
\end{tabular}




\section{Table A5 continued}

\begin{tabular}{|c|c|c|c|c|c|}
\hline No. & Corridor & & & & $\mathrm{BCP2}$ \\
\hline 30 & $6 d$ & KAZ & Bolashak & TKM & Serkhetyaka \\
\hline 31 & $2 d$ & AFG & Aqina & TKM & Imam Nazar \\
\hline 32 & $2 d, 6 d$ & AFG & Torghondi & TKM & Serkhet Abad \\
\hline 33 & $5 b$ & PRC & Khunjerab & PAK & Sost \\
\hline 34 & $5 c, 6 a, 6 b, 6 d$ & AFG & Chaman & PAK & Spin Buldak \\
\hline 35 & $5 a, 6 c$ & AFG & Torkham & PAK & Peshawar \\
\hline 36 & $4 c$ & PRC & Zuun Khatavch & MON & Bichigt \\
\hline
\end{tabular}

$\mathrm{AFG}=$ Afghanistan, $\mathrm{AZE}=$ Azerbaijan, $\mathrm{BCP}=$ border-crossing point, GEO = Georgia, IRN = Iran, KAZ = Kazakhstan, $\mathrm{KGZ}=\mathrm{Kyrgyz}$ Republic, MON = Mongolia, PAK = Pakistan, PRC = People's Republic of China, RUS = Russian Federation, TAJ = Tajikistan, TKM $=$ Turkmenistan, UZB = Uzbekistan.

Source: Asian Development Bank. 

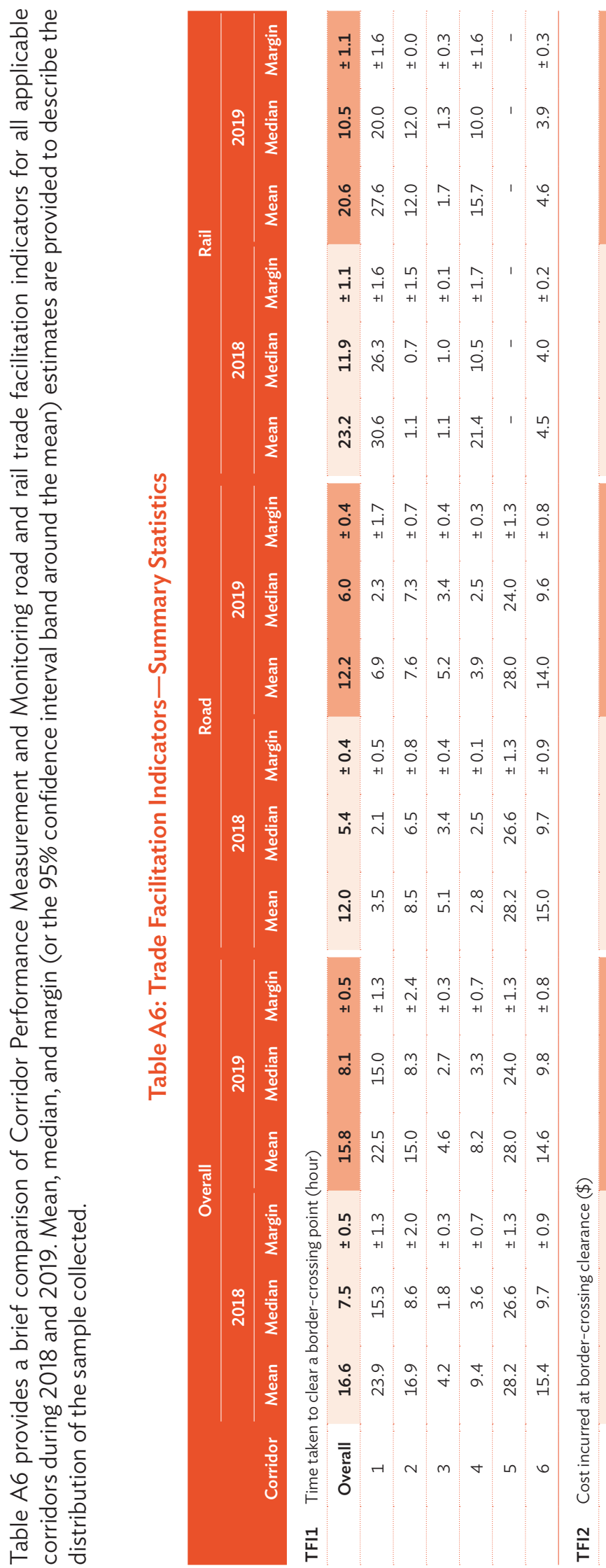

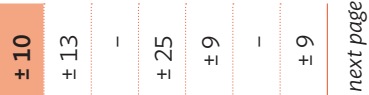

đัન

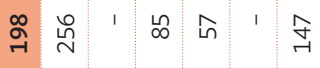

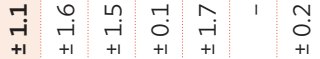

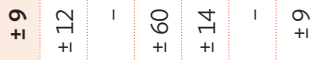

Fे

్ㅗ

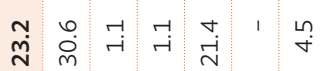

号

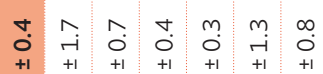

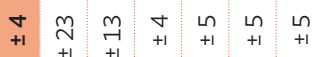

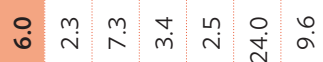

जै $\hat{m}$ ป艹

تี

임 苂

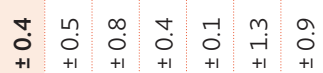

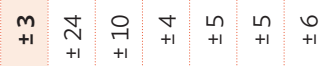

한

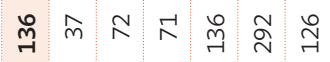

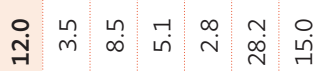

苟号

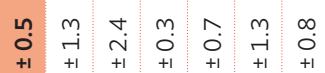

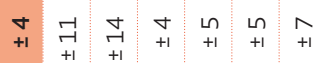

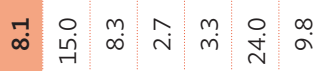

ஸेํำ

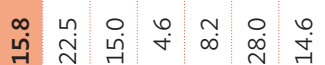

莳

un $m \circ m \wedge m a$ \&

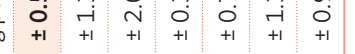

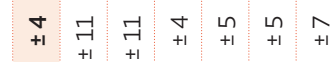

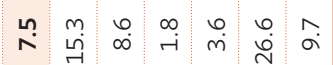

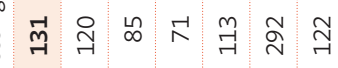

๘

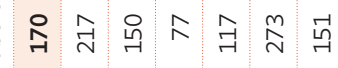

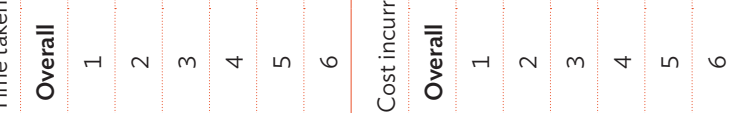

한 


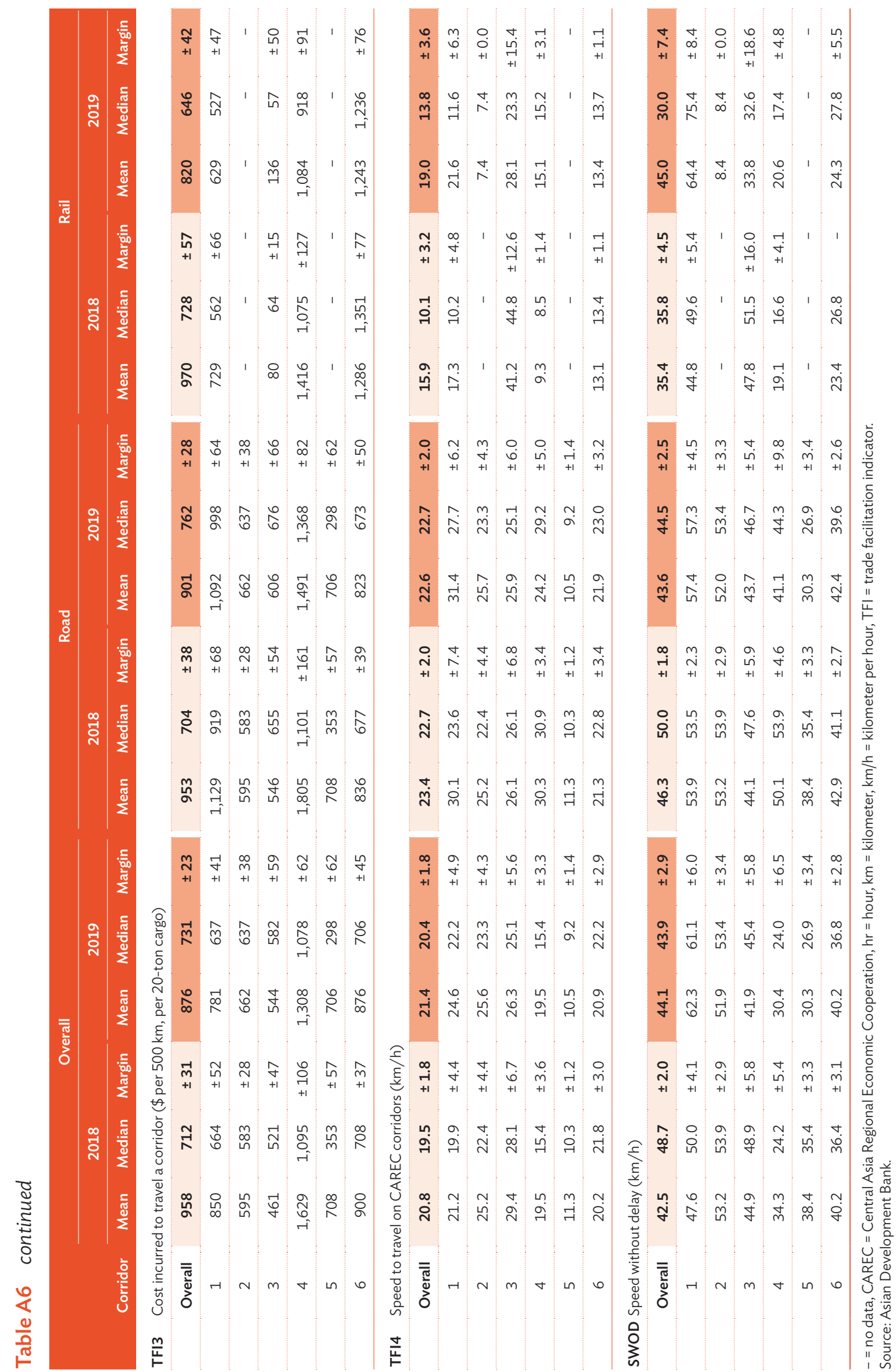




\section{Activities at Road Border-Crossing Points}

Table A7.1 shows the time and cost spent on activities of outbound road shipments from the indicated country at selected border crossing points.

Table A7.1: Time and Cost Spent at Road Border-Crossing Points, Outbound

\begin{tabular}{|c|c|c|c|c|c|c|c|c|c|c|c|c|c|c|c|c|c|c|c|c|c|c|c|}
\hline \multirow[b]{3}{*}{$\mathrm{BCP}$} & \multirow[b]{3}{*}{ Country } & \multirow[b]{3}{*}{ Corridor } & \multirow[b]{3}{*}{ Count } & \multicolumn{20}{|c|}{ Duration (hours) } \\
\hline & & & & \multicolumn{2}{|c|}{ Total } & \multicolumn{18}{|c|}{ Activities } \\
\hline & & & & Average & Median & $\mathrm{i}$ & ii & $\mathrm{iii}$ & iv & $\mathbf{v}$ & vi & vii & viii & ix & $x$ & $\mathrm{xi}$ & xii & xiii & xiv & $\mathbf{x v}$ & xvi & xvii & xviii \\
\hline Chaman & PAK & 5,6 & 128 & 60.1 & 68.0 & 0.7 & 40.7 & & & & & 0.5 & & & 0.5 & & 0.6 & & & & & & 17.8 \\
\hline Kuryk & KAZ & 2 & 8 & 44.7 & 48.0 & 0.2 & 0.3 & & & & & & & & & & 0.2 & & & & & 0.2 & 43.9 \\
\hline Peshawar & PAK & 5,6 & 472 & 35.7 & 28.3 & & 28.5 & & & & & & & & & & 0.6 & & & & 4.2 & & 10.7 \\
\hline Torghondi & AFG & 2,6 & 84 & 28.2 & 29.4 & 0.6 & 0.8 & & & & & & & & 0.5 & & 0.6 & & & & 3.5 & & 22.4 \\
\hline $\begin{array}{l}\text { Shirkhan } \\
\text { Bandar }\end{array}$ & AFG & $2,5,6$ & 120 & 14.2 & 13.9 & 1.0 & 0.9 & 0.7 & 0.5 & 0.5 & & 0.6 & & & 0.5 & & & & & & 4.4 & & 5.8 \\
\hline Tsiteli Khidi & GEO & 2 & 46 & 13.4 & 9.7 & 0.1 & 0.1 & & & & & 0.2 & 0.1 & & & 0.1 & 0.2 & & & & & 0.1 & 13.3 \\
\hline Tazhen & KAZ & 2,6 & 113 & 11.8 & 11.5 & 1.0 & 2.0 & & 0.5 & 0.5 & & 0.2 & 0.1 & 0.7 & & 0.7 & 0.6 & 0.5 & & 3.0 & & 0.1 & 6.6 \\
\hline $\begin{array}{l}\text { Pakhtaabad } \\
\text { (Dusti) }\end{array}$ & TAJ & 3 & 17 & 11.0 & 11.1 & 1.3 & 2.4 & & 0.6 & 0.5 & & & & & & 0.6 & 0.7 & 0.5 & & & & & 4.5 \\
\hline Horgos & PRC & 1 & 54 & 11.0 & 6.9 & 0.3 & 1.2 & 0.8 & 0.1 & & & 0.2 & 0.3 & & & 0.4 & 0.5 & 1.3 & & & 3.8 & & 4.2 \\
\hline Yallama & UZB & 3,6 & 97 & 10.0 & 10.1 & 0.9 & 1.9 & & 0.6 & 0.5 & 0.1 & 0.2 & & & & 0.7 & 0.6 & 0.5 & & & & & 4.7 \\
\hline Dautota & UZB & 2,6 & 124 & 9.6 & 9.3 & 0.6 & 1.4 & & 0.4 & 0.4 & 0.1 & 0.2 & 0.1 & & & 0.7 & 0.5 & 0.6 & & & & & 6.0 \\
\hline Alat & UZB & 2,3 & 59 & 9.5 & 9.5 & 0.9 & 2.0 & & 0.5 & 0.6 & & & & & & 0.7 & 0.7 & 0.5 & & & & & 4.0 \\
\hline Sarahs & TKM & 3 & 12 & 7.6 & 7.3 & 0.9 & 1.5 & & & & & & & & & 0.6 & 0.6 & 0.6 & & & & & 3.5 \\
\hline Farap & TKM & 2,3 & 35 & 7.5 & 7.4 & 0.8 & 1.4 & & & & & & & & & 0.7 & 0.6 & 0.6 & 0.4 & & & & 3.5 \\
\hline Krasnyi Most & AZE & 2 & 12 & 7.4 & 6.5 & 0.2 & 0.2 & 0.3 & & & & & 0.1 & & & 0.1 & 0.1 & & & & & 0.3 & 8.2 \\
\hline Erenhot & PRC & 4 & 337 & 6.7 & 3.1 & 0.3 & 1.3 & 0.6 & & & & 0.3 & & & & 0.1 & 0.6 & 0.1 & & & & & 7.3 \\
\hline Takeshikent & PRC & 4 & 48 & 6.3 & 6.3 & 0.2 & 1.0 & 0.8 & & & & 0.2 & & & & & & & & & 3.7 & & 0.5 \\
\hline Kairak & $\mathrm{KAZ}$ & 1 & 2 & 5.7 & 5.7 & 0.3 & & & & 0.2 & & 0.3 & 0.1 & & & 0.2 & 0.1 & & & & & & 10.0 \\
\hline Nur Zholy & $\mathrm{KAZ}$ & 1 & 1 & 5.2 & 5.2 & 0.2 & 0.5 & & 0.1 & 0.2 & & 0.1 & 0.1 & & & & 0.1 & & & & & & 4.0 \\
\hline Hairatan & AFG & 3,6 & 156 & 4.9 & 4.9 & 0.7 & 0.6 & & & & & & & & 0.5 & & & & & & 2.6 & 0.5 & \\
\hline Saryasia & UZB & 3 & 123 & 4.6 & 3.9 & 0.3 & 1.9 & & 0.2 & 0.4 & 0.3 & 0.2 & 0.2 & & & 0.4 & 0.6 & 0.6 & & 0.6 & & & 4.6 \\
\hline Konysbayeva & KAZ & 3,6 & 1 & 4.4 & 4.4 & 0.3 & 0.7 & & 0.1 & & & 0.2 & 0.1 & & & & 0.2 & & & & & & 3.0 \\
\hline Karasu & PRC & 0 & 74 & 4.1 & 3.6 & 0.2 & 0.5 & & 0.2 & & & 0.2 & & & & & 0.5 & & & & & & 2.9 \\
\hline Panji Poyon & TAJ & $2,5,6$ & 131 & 3.8 & 2.3 & 0.2 & 0.4 & & 0.2 & 0.2 & 0.2 & 0.2 & & & 0.1 & 0.2 & 0.2 & 0.3 & & & 0.5 & & 23.6 \\
\hline Uchkurgan & UZB & 0 & 1 & 3.0 & 3.0 & 0.3 & 0.3 & & 0.1 & & & 0.2 & 0.1 & & & & & & & & & & 2.0 \\
\hline Yarant & MON & 4 & 12 & 2.9 & 3.0 & 0.2 & 2.6 & & & & & 0.2 & & & & & & & & & & & \\
\hline Ozinki & RUS & 1,6 & 6 & 2.8 & 2.7 & 0.2 & & & 0.1 & 0.2 & & 0.2 & 0.1 & & & 0.1 & 0.2 & & & & & & 3.0 \\
\hline Merke & KAZ & 1,3 & 12 & 2.7 & 2.0 & 0.8 & & & & & & & & & & & & & & & & & 2.5 \\
\hline Krasnyi Yar & RUS & 6 & 2 & 2.6 & 2.6 & 0.2 & & & 0.1 & 0.1 & & 0.1 & 0.1 & & & 0.1 & 0.1 & & & & & & 2.0 \\
\hline Kurmangazy & $\mathrm{KAZ}$ & 6 & 51 & 2.5 & 2.2 & 0.5 & 3.8 & & 0.1 & 0.1 & & 0.2 & 0.1 & & & 0.1 & 0.1 & & & & 5.0 & & 1.6 \\
\hline Termez & UZB & 3,6 & 1 & 2.3 & 2.3 & 0.3 & 0.7 & & & & & & & & & 0.2 & 0.3 & & & & 1.0 & & \\
\hline Karamyk & $K G Z$ & $2,3,5$ & 28 & 2.1 & 2.3 & 0.3 & 0.3 & & 0.4 & 0.2 & 0.3 & 0.3 & & & & 0.3 & & 0.3 & & & & & \\
\hline
\end{tabular}




\section{Table A7.1 continued}

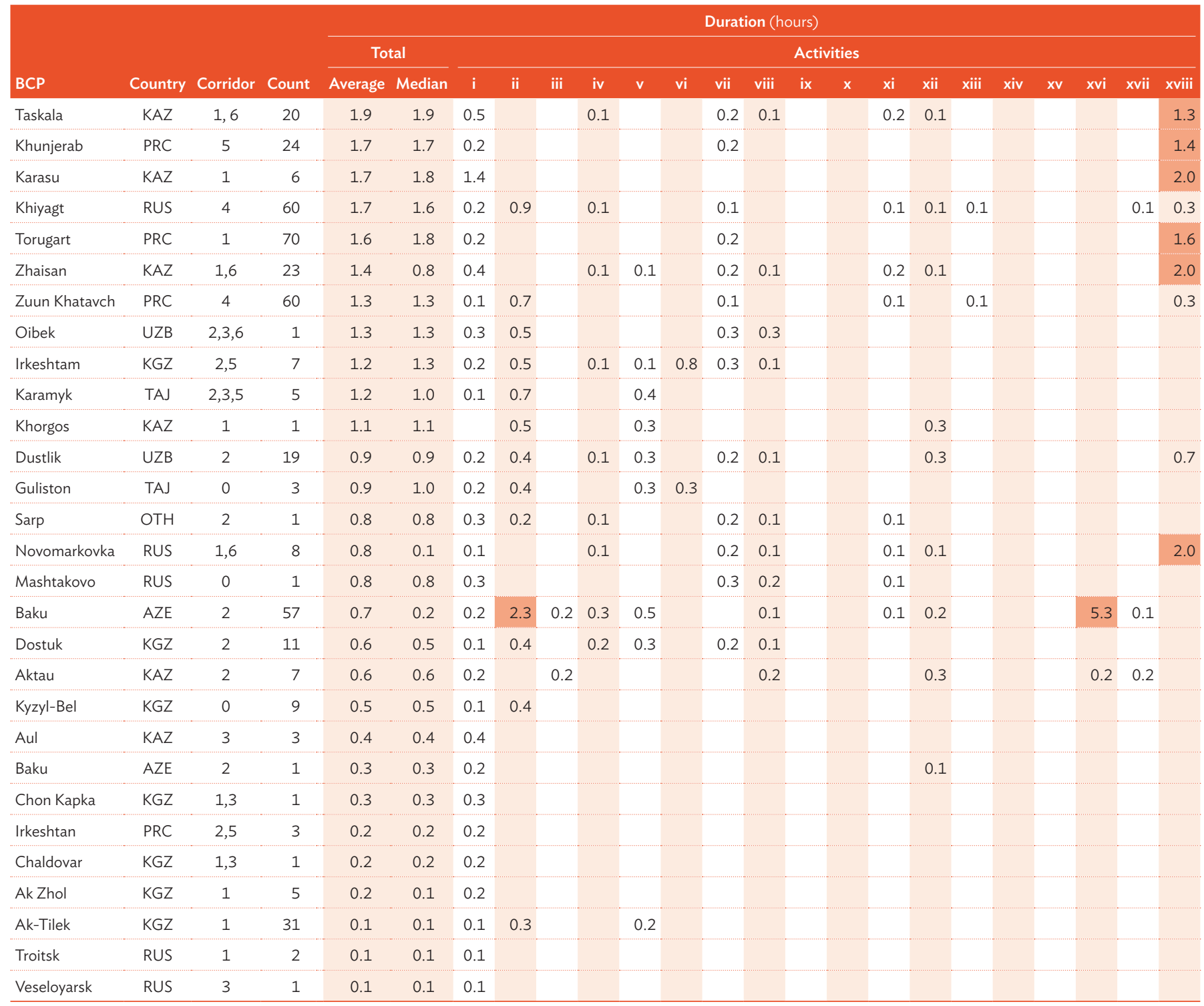


Table A7.1 continued

\begin{tabular}{|c|c|c|c|c|c|c|c|c|c|c|c|c|c|c|c|c|c|c|c|c|c|c|c|}
\hline \multirow[b]{3}{*}{$\mathrm{BCP}$} & \multirow[b]{3}{*}{ Country } & \multirow[b]{3}{*}{ Corridor } & \multirow[b]{3}{*}{ Count } & \multicolumn{20}{|c|}{ Cost $(\$)$} \\
\hline & & & & \multicolumn{2}{|c|}{ Total } & \multicolumn{18}{|c|}{ Activities } \\
\hline & & & & Average & Median & $\mathrm{i}$ & ii & $\mathrm{iii}$ & iv & $\mathbf{v}$ & vi & vii & viii & ix & $\mathrm{x}$ & $\mathbf{x i}$ & xii & xiii & xiv & $\mathrm{xv}$ & xvi & xvii & xviii \\
\hline Kuryk & KAZ & 2 & 8 & 204 & 180 & 4 & 159 & & & & & & & & & & - & & & & & 40 & 3 \\
\hline Peshawar & PAK & 5,6 & 472 & 319 & 292 & & 284 & & & & & & & & & & 10 & & & & 50 & & \\
\hline Torghondi & $\mathrm{AFG}$ & 2,6 & 84 & 311 & 310 & 9 & 69 & & & & & & & & 9 & & 15 & & & & 210 & & \\
\hline Tsiteli Khidi & GEO & 2 & 46 & 52 & 70 & - & - & & & & & - & - & & & - & - & & & & & 73 & 1 \\
\hline Tazhen & KAZ & 2,6 & 113 & 100 & 114 & 10 & 27 & & 15 & 16 & & & & 20 & & 15 & 16 & 20 & & - & & - & 6 \\
\hline $\begin{array}{l}\text { Pakhtaabad } \\
\text { (Dusti) }\end{array}$ & TAJ & 3 & 17 & 108 & 112 & 8 & 21 & & 15 & 15 & & & & & & 14 & 16 & 19 & & & & & \\
\hline Sarahs & TKM & 3 & 12 & 62 & 61 & 14 & 18 & & & & & & & & & 13 & 12 & 9 & & & & & \\
\hline Farap & TKM & 2,3 & 35 & 63 & 63 & 12 & 19 & & & & & & & & & 13 & 11 & 8 & 9 & & & & \\
\hline Krasnyi Most & AZE & 2 & 12 & 23 & 23 & 1 & 12 & 6 & & & & & 5 & & & 6 & 9 & & & & & 36 & - \\
\hline Erenhot & PRC & 4 & 337 & 144 & 173 & 4 & 90 & 13 & & & & - & & & & & 45 & & & & & & - \\
\hline Takeshikent & PRC & 4 & 48 & 309 & 271 & - & 72 & 44 & & & & - & & & & & & & & & 183 & & 9 \\
\hline Kairak & KAZ & 1 & 2 & 8 & 8 & 8 & & & & & & & & & & & & & & & & & \\
\hline Nur Zholy & $\mathrm{KAZ}$ & 1 & 1 & 150 & 150 & & 150 & & & & & & & & & & & & & & & & \\
\hline Hairatan & AFG & 3,6 & 156 & 145 & 146 & 9 & 10 & & & & & & & & 9 & & & & & & 109 & 9 & \\
\hline Saryasia & UZB & 3 & 123 & 101 & 81 & 14 & 23 & & 8 & 5 & 10 & 5 & & & & 8 & & 5 & & 54 & & & 2 \\
\hline Merke & KAZ & 1,3 & 12 & 12 & 10 & 12 & & & & & & & & & & & & & & & & & \\
\hline Krasnyi Yar & RUS & 6 & 2 & & & & & & & & & & & & & & & & & & & & \\
\hline Kurmangazy & $\mathrm{KAZ}$ & 6 & 51 & 10 & 10 & 10 & & & 5 & 8 & & & & & & & & & & & & & \\
\hline Termez & UZB & 3,6 & 1 & & & & & & & & & & & & & & & & & & & & \\
\hline Karamyk & KGZ & $2,3,5$ & 28 & 45 & 48 & 3 & 23 & & 3 & 4 & 5 & 3 & & & & 3 & & 3 & & & & & \\
\hline Taskala & $\mathrm{KAZ}$ & 1,6 & 20 & 10 & 8 & 10 & & & & & & & & & & & & & & & & & \\
\hline Khunjerab & PRC & 5 & 24 & - & - & - & & & & & & - & & & & & & & & & & & - \\
\hline Karasu & KAZ & 1 & 6 & 15 & 13 & 15 & & & & & & & & & & & & & & & & & \\
\hline Khiyagt & RUS & 4 & 60 & 8 & 8 & & & & & & & & & & & & & & & & & 8 & \\
\hline Torugart & PRC & 1 & 70 & - & - & - & & & & & & - & & & & & & & & & & & - \\
\hline Zhaisan & KAZ & 1,6 & 23 & 14 & 13 & 14 & & & 5 & 5 & & & & & & & & & & & & & \\
\hline Zuun Khatavch & PRC & 4 & 60 & 16 & 16 & & 16 & & & & & & & & & & & & & & & & \\
\hline Oibek & UZB & $2,3,6$ & 1 & & & & & & & & & & & & & & & & & & & & \\
\hline
\end{tabular}




\section{Table A7.1 continued}

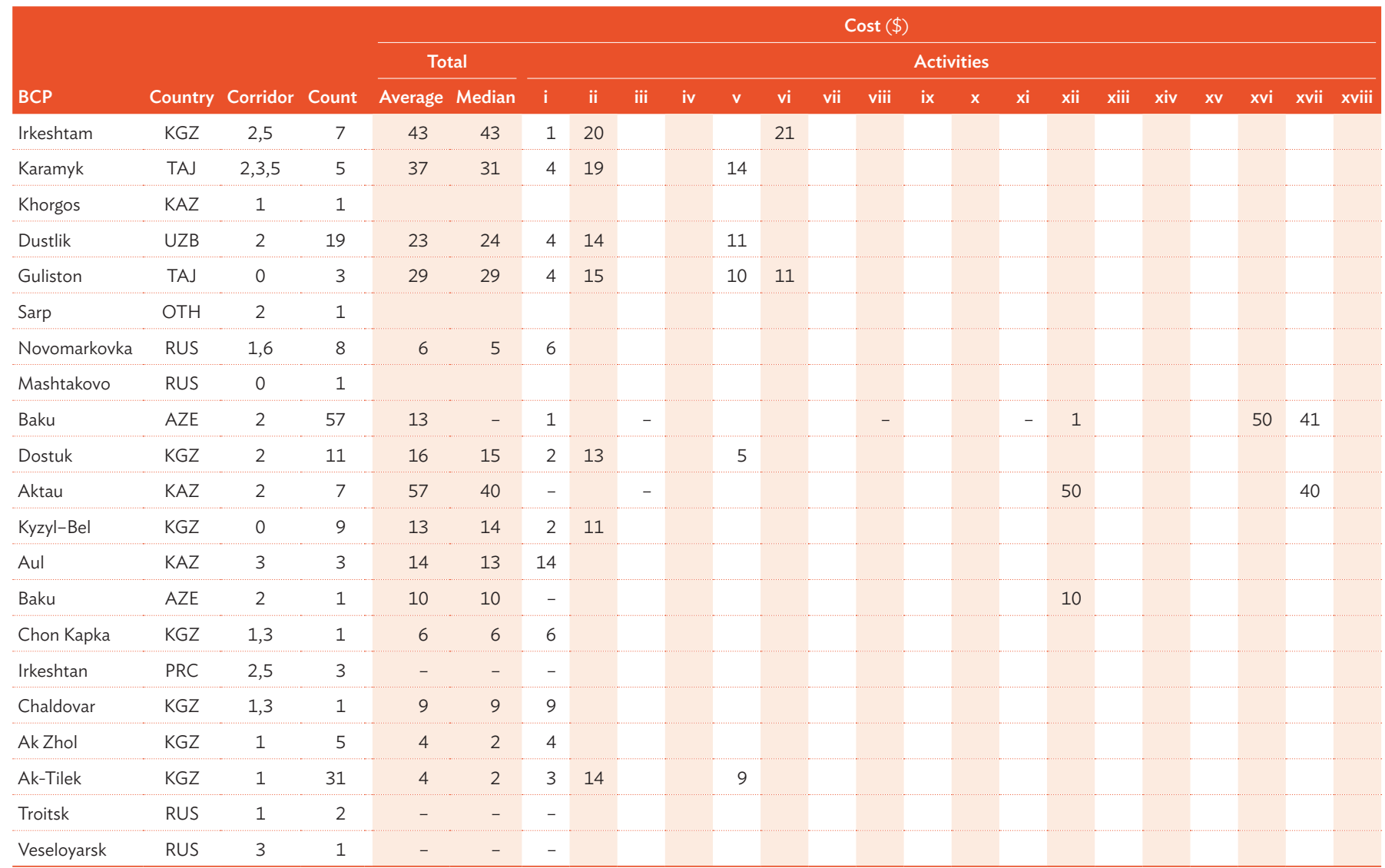

More than one hour More than $\$ 100$

i. Border security and control, ii. Customs controls, iii. Commercial inspection, iv. Health and quarantine, v. Phytosanitary inspection, vi. Veterinary inspection, vii. Visa or immigration, viii. Transit conformity, ix. GAl or traffic inspection, x. Police checkpoint or stop, xi. Transport inspection, xii. Weight or standard inspection, xiii. Vehicle registration, xiv. Emergency repair, xv. Escort or convoy, xvi. Loading and/or unloading, xvii. Road or bridge toll, xviii. Waiting or queue.

$-=$ no data, $\mathrm{AFG}=$ Afghanistan, $\mathrm{AZE}=$ Azerbaijan, $\mathrm{BCP}=$ border-crossing point, $\mathrm{GEO}=$ Georgia, IRN = Iran, $\mathrm{KAZ}=\mathrm{Kazakhstan}, \mathrm{KGZ}=\mathrm{Kyrgyz}$ Republic, $\mathrm{MON}=\mathrm{Mongolia}$ PAK $=$ Pakistan, $\mathrm{PRC}=$ People's Republic of China, $\mathrm{RUS}=$ Russian Federation, TAJ $=$ Tajikistan, $\mathrm{TKM}=$ Turkmenistan, UZB $=$ Uzbekistan.

Source: Asian Development Bank. 
Table A7.2 shows the time and cost spent on activities of inbound road shipments to the indicated country at selected border-crossing points.

Table A7.2: Time and Cost Spent at Road Border-Crossing Points, Inbound

\begin{tabular}{|c|c|c|c|c|c|c|c|c|c|c|c|c|c|c|c|c|c|c|c|c|c|c|c|}
\hline \multirow[b]{3}{*}{$\mathrm{BCP}$} & \multirow[b]{3}{*}{ Country } & \multirow[b]{3}{*}{ Corridor } & \multirow[b]{3}{*}{ Count } & \multicolumn{20}{|c|}{ Duration (hours) } \\
\hline & & & & \multicolumn{2}{|c|}{ Total } & \multicolumn{18}{|c|}{ Activities } \\
\hline & & & & Average & Median & $\mathrm{i}$ & ii & iii & iv & v & vi & vii & viii & ix & $\mathrm{x}$ & $\mathrm{xi}$ & xii & xiii & xiv & $x v$ & $\mathrm{xvi}$ & xvii & xviii \\
\hline Spin Buldak & AFG & 5,6 & 128 & 25.3 & 13.8 & 0.5 & 12.9 & & & & & 0.6 & 0.6 & & & 0.5 & & & & & 0.4 & & 11.3 \\
\hline Torkham & AFG & 5,6 & 472 & 23.5 & 11.6 & 0.7 & 13.4 & & & & & 0.5 & & 0.5 & 0.6 & 0.5 & & & & & & 0.5 & 11.4 \\
\hline Veseloyarsk & RUS & 3 & 3 & 18.7 & 0.1 & 2.7 & & & & & & & & & & & & & & & & & 48.0 \\
\hline Horgos & PRC & 1 & 1 & 15.7 & 15.7 & 0.3 & 0.7 & & 0.1 & 1.0 & & 0.5 & 0.1 & & & & 0.1 & 1.0 & & & 4.0 & & 8.0 \\
\hline Kuryk & KAZ & 2 & 33 & 14.8 & 10.9 & 0.2 & 0.3 & 0.2 & & 0.1 & 0.1 & & 0.2 & & & 0.1 & 0.1 & & & 10.6 & & 0.1 & 12.5 \\
\hline Konysbayeva & KAZ & 3,6 & 99 & 11.6 & 12.3 & 1.2 & 2.3 & 0.2 & 0.5 & 0.6 & & 0.2 & 0.2 & & & 0.7 & 0.6 & 0.5 & & & & & 5.4 \\
\hline Farap & TKM & 2,3 & 59 & 10.2 & 9.9 & 0.9 & 2.0 & & 0.5 & 0.5 & 0.6 & 0.6 & & & & 0.7 & 0.6 & 0.6 & & & & 0.4 & 4.1 \\
\hline Sarahs & TKM & 3 & 18 & 9.4 & 9.2 & 1.0 & 1.8 & & & 0.5 & & 0.6 & & & & 0.7 & 0.6 & 0.6 & & & & 0.4 & 3.5 \\
\hline Tazhen & KAZ & 2,6 & 124 & 8.7 & 10.8 & 0.8 & 1.7 & 0.2 & 0.4 & 0.4 & 0.2 & 0.2 & 0.2 & & & 0.6 & 0.5 & 0.6 & & & & & 4.8 \\
\hline Dautota & UZB & 2,6 & 214 & 7.6 & 6.5 & 0.5 & 2.6 & 0.1 & 0.4 & 0.5 & 0.3 & 0.2 & 0.1 & & & 0.6 & 0.6 & 0.5 & & 1.9 & 0.2 & 0.3 & 4.2 \\
\hline Panji Poyon & TAJ & $2,5,6$ & 120 & 7.2 & 6.3 & 1.1 & 0.9 & 0.9 & 0.4 & 0.7 & & 0.6 & & & 0.6 & & & & 5.3 & & & & \\
\hline Sarpi & GEO & 2 & 2 & 6.2 & 6.2 & 0.2 & 0.3 & 0.2 & 0.1 & & & 0.1 & 0.1 & & & 0.2 & 0.2 & 0.3 & & & & & 10.0 \\
\hline Turkmenbashi & TKM & 2 & 1 & 6.0 & 6.0 & & & & & & & & & & & & & & & & & & 6.0 \\
\hline Khorgos & KAZ & 1 & 36 & 5.7 & 5.9 & 0.2 & 2.7 & & & & & 0.2 & & & & & & & & & & & 2.6 \\
\hline Krasnyi Most & AZE & 2 & 48 & 4.6 & 4.7 & 0.1 & 0.2 & 0.2 & 0.1 & 0.1 & 0.1 & & 0.1 & & & 0.1 & 0.2 & & & & & 0.1 & 4.0 \\
\hline Zamiin-Uud & MON & 4 & 337 & 4.5 & 4.7 & 1.2 & 1.8 & 0.7 & 0.1 & & & 0.6 & & & & 0.1 & 0.1 & 0.1 & & & & 0.3 & 0.3 \\
\hline Tsiteli Khidi & GEO & 2 & 11 & 2.1 & 2.2 & 0.1 & 0.1 & 0.1 & & 0.1 & & & & & & & & & & & & & 1.9 \\
\hline Kurmangazy & KAZ & 6 & 58 & 2.1 & 1.7 & 0.6 & 3.3 & & 0.1 & 0.2 & & 0.1 & 0.2 & & & & 0.1 & & & & 4.8 & & 1.2 \\
\hline Troitsk & RUS & 1 & 2 & 2.1 & 2.1 & 0.1 & & & 0.1 & 0.2 & & 0.2 & 0.1 & & & 0.2 & 0.1 & & & & & 0.2 & 3.0 \\
\hline Kairak & KAZ & 1 & 1 & 2.0 & 2.0 & 2.0 & & & & & & & & & & & & & & & & & \\
\hline Fotehobod & TAJ & $2,3,6$ & 1 & 1.9 & 1.9 & 0.3 & 0.5 & & 0.3 & & & 0.2 & 0.1 & & & 0.2 & 0.3 & & & 0.3 & & & \\
\hline Altanbulag & MON & 4 & 60 & 1.9 & 1.8 & 0.2 & 1.1 & & 0.2 & & & 0.1 & & & & 0.1 & 0.1 & 0.1 & & & & 0.1 & 0.3 \\
\hline Pogodaevo & KAZ & 0 & 17 & 1.9 & 2.0 & 0.7 & & & & & & & & & & & & & & & & & 1.2 \\
\hline Khunjerab & PAK & 5 & 24 & 1.8 & 2.0 & 0.2 & & & & & & 0.2 & & & & & & & & & & & 1.4 \\
\hline Chaldovar & KGZ & 1,3 & 11 & 1.7 & 2.2 & 0.5 & & & & & & & & 0.2 & & & & & & & & & 1.6 \\
\hline Irkeshtan & PRC & 2,5 & 7 & 1.6 & 0.9 & 0.4 & & & 0.2 & & & 0.2 & 0.1 & & & & & & & & & & 6.0 \\
\hline
\end{tabular}


Table A7.2 continued

\begin{tabular}{|c|c|c|c|c|c|c|c|c|c|c|c|c|c|c|c|c|c|c|c|c|c|c|c|}
\hline \multirow[b]{3}{*}{$\mathrm{BCP}$} & \multirow[b]{3}{*}{ Country } & \multirow[b]{3}{*}{ Corridor } & \multirow[b]{3}{*}{ Count } & \multicolumn{20}{|c|}{ Duration (hours) } \\
\hline & & & & \multicolumn{2}{|c|}{ Total } & \multicolumn{18}{|c|}{ Activities } \\
\hline & & & & Average & Median & $\mathrm{i}$ & ii & iii & iv & $\mathbf{v}$ & vi & vii & viii & ix & $x$ & $\mathbf{x i}$ & xii & xiii & xiv & $x v$ & xvi & xvii & xviii \\
\hline Bichigt & MON & 4 & 60 & 1.4 & 1.4 & 0.1 & 0.8 & & & & & 0.1 & & & & 0.1 & 0.1 & 0.1 & & & & & 0.3 \\
\hline Kensay & KGZ & 0 & 1 & 1.4 & 1.4 & 0.5 & 0.3 & & 0.2 & & & 0.3 & 0.1 & & & & 0.2 & & & & & & \\
\hline Krasnyi Yar & RUS & 6 & 16 & 1.3 & 1.1 & 0.2 & & & 0.1 & 0.2 & & 0.2 & 0.1 & & & 0.1 & 0.1 & & & & & 0.2 & 1.0 \\
\hline Mashtakovo & RUS & 0 & 14 & 1.1 & 1.0 & 0.2 & & & 0.1 & 0.2 & 0.2 & 0.2 & 0.1 & & & 0.1 & 0.1 & & & & & 0.2 & 0.8 \\
\hline Aktau & KAZ & 2 & 17 & 1.0 & 0.4 & 0.2 & & & & & & & 0.1 & & 0.1 & & 0.1 & & & 2.1 & & 0.1 & \\
\hline Dostuk & KGZ & 2 & 18 & 1.0 & 1.0 & 0.2 & 0.5 & & 0.2 & 0.2 & & 0.1 & 0.1 & & & & 0.2 & & & & & 0.1 & \\
\hline Kyzyl-Bel & KGZ & 0 & 3 & 0.9 & 0.8 & 0.1 & 0.6 & & & 0.2 & 0.3 & & & & & & & & & & & & \\
\hline Ozinki & RUS & 1,6 & 4 & 0.9 & 0.9 & 0.1 & & & 0.1 & & & 0.1 & 0.1 & & & 0.1 & 0.2 & & & & & 0.2 & \\
\hline Guliston & TAJ & 0 & 11 & 0.6 & 0.6 & 0.1 & 0.5 & & & 0.3 & & & & & & & & & & & & & \\
\hline Dustlik & UZB & 2 & 12 & 0.6 & 0.5 & 0.1 & 0.5 & & & & & 0.2 & & & & & 0.2 & & & & & & \\
\hline Jalgan & TAJ & $2,3,5$ & 24 & 0.6 & 0.4 & & & & & & & & & & & 0.2 & & 0.2 & & 0.5 & & & \\
\hline Zhaisan & KAZ & 1,6 & 8 & 0.6 & 0.4 & 0.4 & & & 0.1 & & & 0.2 & 0.1 & & & 0.2 & 0.1 & & & & & & 0.5 \\
\hline Karamyk & KGZ & $2,3,5$ & 5 & 0.6 & 0.6 & 0.1 & 0.4 & & & 0.1 & & & & & & & & & & & & & \\
\hline Aul & KAZ & 3 & 1 & 0.4 & 0.4 & 0.4 & & & & & & & & & & & & & & & & & \\
\hline Baku & AZE & 2 & 15 & 0.4 & 0.4 & 0.1 & & 0.2 & & 0.1 & & & 0.2 & & & 0.1 & 0.2 & & & & & 0.2 & \\
\hline Kordai & KAZ & 1 & 1 & 0.2 & 0.2 & 0.2 & & & & & & & & & & & & & & & & & \\
\hline Ak-Tilek & KGZ & 1 & 7 & 0.1 & 0.1 & 0.1 & & & & & & & & & & & & & & & & & \\
\hline
\end{tabular}


Table A7.2 continued

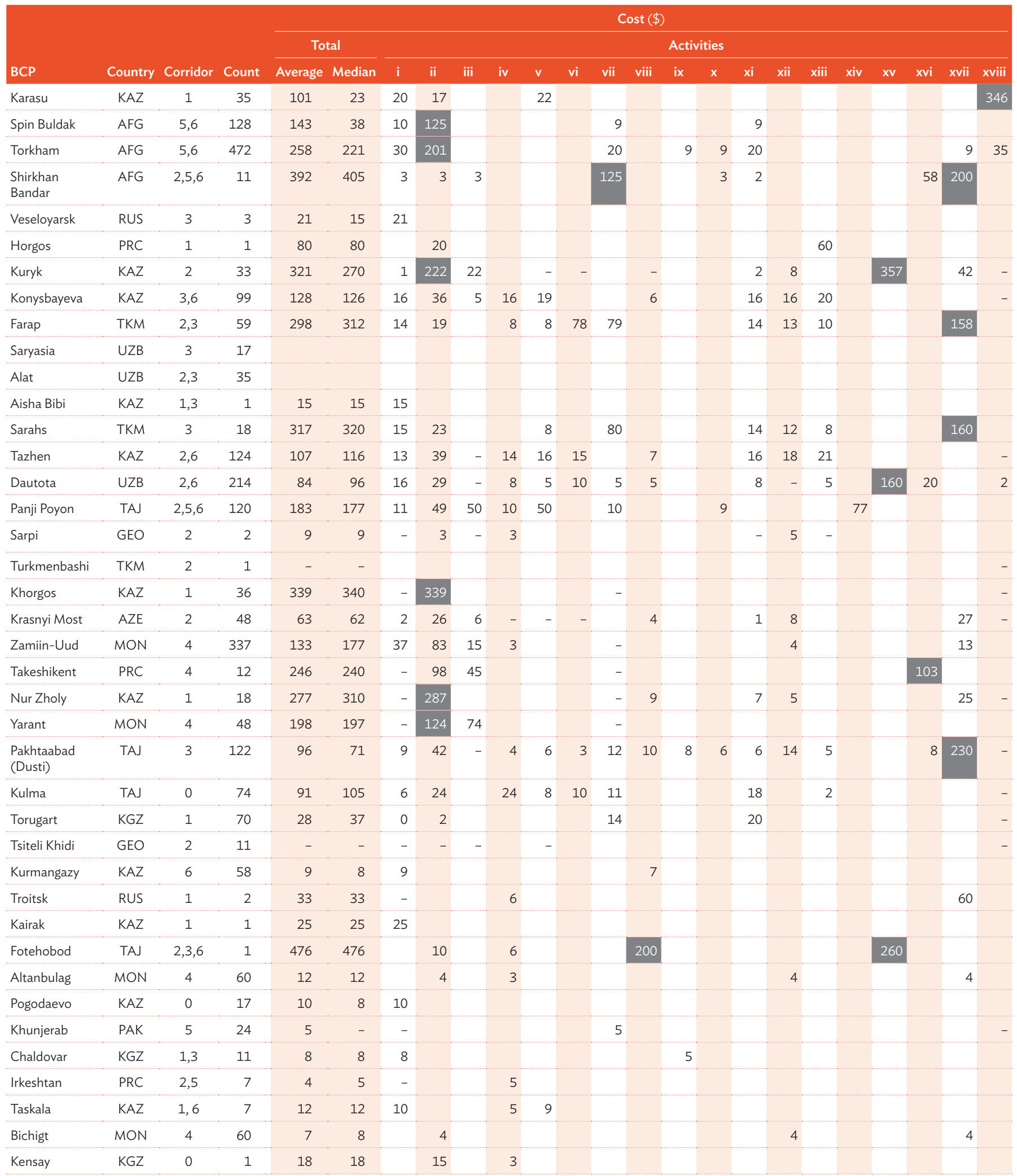


Table A7.2 continued

\begin{tabular}{|c|c|c|c|c|c|c|c|c|c|c|c|c|c|c|c|c|c|c|c|c|c|c|c|}
\hline \multirow[b]{3}{*}{$\mathrm{BCP}$} & \multirow[b]{3}{*}{ Country } & \multirow[b]{3}{*}{ Corridor } & \multirow[b]{3}{*}{ Count } & \multicolumn{20}{|c|}{ Cost $(\$)$} \\
\hline & & & & \multicolumn{2}{|c|}{ Total } & \multicolumn{18}{|c|}{ Activities } \\
\hline & & & & Average & Median & $\mathrm{i}$ & ii & iii & iv & $\mathbf{v}$ & vi & vii & viii & ix & $x$ & $\mathrm{xi}$ & xii & xiii & xiv & $x v$ & xvi & $\mathrm{xvii}$ & xviii \\
\hline Krasnyi Yar & RUS & 6 & 16 & 69 & 60 & & & & & & & & 15 & & & & & & & & & 68 & \\
\hline Yallama & UZB & 3,6 & 1 & 10 & 10 & & & & & & & & 10 & & & & & & & & & & \\
\hline Mashtakovo & RUS & 0 & 14 & 69 & 73 & & & & & & & & & & & & & & & & & 69 & \\
\hline Aktau & KAZ & 2 & 17 & 130 & 145 & - & & & & & & & - & & 5 & & 37 & & & 168 & 200 & 36 & \\
\hline Dostuk & KGZ & 2 & 18 & 22 & 21 & 2 & 12 & & 3 & 7 & & 10 & 7 & & & & & & & & & 25 & \\
\hline Kyzyl-Bel & KGZ & 0 & 3 & 23 & 27 & 2 & 14 & & & 8 & 5 & & & & & & & & & & & & \\
\hline Ozinki & RUS & 1,6 & 4 & 103 & 105 & & & & & & & & & & & & & & & & & 103 & \\
\hline Novomarkovka & RUS & 1,6 & 23 & 40 & 5 & 0 & & & & & & & & & & & & & & & & 83 & \\
\hline Irkeshtam & $K G Z$ & 2,5 & 3 & 15 & 15 & 1 & 14 & & & & & & & & & & & & & & & & \\
\hline Karamyk & TAJ & $2,3,5$ & 4 & 26 & 23 & 5 & 15 & & & 12 & & & & & & & & & & & & & \\
\hline Guliston & TAJ & 0 & 11 & 21 & 20 & 3 & 17 & & & 5 & & & & & & & & & & & & & \\
\hline Dustlik & UZB & 2 & 12 & 20 & 19 & 3 & 17 & & & & & & & & & & & & & & & & \\
\hline Jalgan & TAJ & $2,3,5$ & 24 & 99 & 99 & 3 & 20 & & 2 & 3 & 2 & 4 & & & & 3 & & 5 & & 114 & & & \\
\hline Zhaisan & KAZ & 1,6 & 8 & 10 & 12 & 11 & & & 5 & & & & & & & & & & & & & & \\
\hline Karamyk & $K G Z$ & $2,3,5$ & 5 & 19 & 18 & 1 & 11 & & & 8 & & & & & & & & & & & & & \\
\hline Aul & KAZ & 3 & 1 & 12 & 12 & 12 & & & & & & & & & & & & & & & & & \\
\hline Baku & AZE & 2 & 15 & 34 & 25 & 1 & & - & & - & & & - & & & - & 1 & & & & 39 & 29 & \\
\hline Kordai & KAZ & 1 & 1 & - & - & - & & & & & & & & & & & & & & & & & \\
\hline Ak-Tilek & $K G Z$ & 1 & 7 & 2 & 1 & 2 & & & & & & & & & & & & & & & & & \\
\hline Merke & KAZ & 1,3 & 1 & 6 & 6 & 6 & & & & & & & & & & & & & & & & & \\
\hline Serkhet Abad & TKM & 2,6 & 12 & & & & & & & & & & & & & & & & & & & & \\
\hline
\end{tabular}

More than one hour More than $\$ 100$

i. Border security and control, ii. Customs controls, iii. Commercial inspection, iv. Health and quarantine, v. Phytosanitary inspection, vi. Veterinary inspection, vii. Visa or immigration, viii. Transit conformity, ix. GAl or traffic inspection, x. Police checkpoint or stop, xi. Transport inspection, xii. Weight or standard inspection, xiii. Vehicle registration, xiv. Emergency repair, xv. Escort or convoy, xvi. Loading and/or unloading, xvii. Road or bridge toll, xviii. Waiting or queue.

- = no data, $\mathrm{AFG}=$ Afghanistan, $\mathrm{AZE}=$ Azerbaijan, $\mathrm{BCP}=$ border-crossing point, $\mathrm{GEO}=$ Georgia, IRN = Iran, $\mathrm{KAZ}=\mathrm{Kazakhstan}, \mathrm{KGZ}=\mathrm{Kyrgyz}$ Republic, MON = Mongolia, PAK = Pakistan, PRC = People's Republic of China, RUS = Russian Federation, TAJ = Tajikistan, TKM = Turkmenistan, UZB $=$ Uzbekistan.

Source: Asian Development Bank. 


\section{APPENDIX 8 \\ Activities at Rail Border-Crossing Points}

Table A8 shows the time and cost spent on activities of inbound and outbound rail shipments to and from the indicated country at selected border-crossing points.

Table A8: Time and Cost Spent at Rail Border-Crossing Points, Outbound and Inbound

\section{Rail Outbound Traffic}

\begin{tabular}{|c|c|c|c|c|c|c|c|c|c|c|c|c|c|c|c|c|c|c|c|c|c|c|c|c|c|c|c|}
\hline \multirow[b]{3}{*}{$\mathrm{BCP}$} & \multirow[b]{3}{*}{ Country } & \multirow[b]{3}{*}{ Corridor } & \multirow[b]{3}{*}{ r Count } & \multicolumn{24}{|c|}{ Duration (hours) } \\
\hline & & & & \multirow{2}{*}{\multicolumn{2}{|c|}{$\frac{\text { Total }}{\text { Average Median }}$}} & \multicolumn{22}{|c|}{ Activities } \\
\hline & & & & & & i & ii & $\mathrm{iii}$ & iv & $\mathbf{v}$ & vi & vii & viii & ix & $\mathbf{x}$ & xi & xii & xiii & xiv & $\mathbf{x v}$ & xvi & xvii & xviii & xix & $\mathbf{x x}$ & xxi & xxii \\
\hline Alashankou & PRC & 1,2 & 133 & 17.3 & 16.8 & & & & & & & & & & & & 1.6 & 0.3 & 0.3 & 0.4 & & & & 15.8 & & & \\
\hline Khodzhadavlet & UZB & 2,3 & 39 & 15.0 & 15.1 & & & & & & & & & & & & 2.6 & & & & & & & 12.4 & & & \\
\hline Erenhot & PRC & 4 & 144 & 11.2 & 10.1 & & & & & & & & & & & 2.4 & 7.6 & & & & & & & 17.2 & & 4.8 & \\
\hline Saryagash & $\mathrm{KAZ}$ & 3,6 & 102 & 9.6 & 14.0 & & & & & & & & & & & & 1.7 & 0.2 & 0.2 & 0.2 & & & & 12.2 & 3.7 & & \\
\hline Zamiin-Uud & MON & 4 & 120 & 8.7 & 10.5 & & & & & & 1.9 & & & & & 1.1 & 0.8 & & & & 8.8 & & & & 2.7 & 2.2 & \\
\hline Horgos & PRC & 1 & 167 & 7.6 & 1.3 & & & & & & & & & 5.0 & & & 0.7 & 0.3 & 0.3 & 0.4 & & & & 21.6 & & & \\
\hline Torghondi & AFG & 2,6 & 84 & 3.8 & 3.9 & 1.6 & 1.6 & & & & & & & & & & 0.7 & & & & & & & & & & \\
\hline Merke & $\mathrm{KAZ}$ & 1,3 & 15 & 2.5 & 2.0 & & & & & & & & & & & & 0.3 & 0.2 & 0.2 & & & & & & 2.9 & & \\
\hline Naushki & RUS & 4 & 48 & 0.7 & 0.6 & & & & & & & & & & 0.7 & & & & & & & & & & & & \\
\hline Bekabad & UZB & 2 & 5 & & & & & & & & & & & & & & & & & & & & & & & & \\
\hline Saryasia & UZB & 3 & 2 & & & & & & & & & & & & & & & & & & & & & & & & \\
\hline
\end{tabular}

\begin{tabular}{|c|c|c|c|c|c|c|c|c|c|c|c|c|c|c|c|c|c|c|c|c|c|c|c|c|c|c|c|}
\hline \multirow[b]{3}{*}{$\mathrm{BCP}$} & \multirow[b]{3}{*}{ Country } & \multirow[b]{3}{*}{ Corridor } & \multirow[b]{3}{*}{ Count } & \multicolumn{24}{|c|}{ Duration (hours) } \\
\hline & & & & \multirow{2}{*}{\multicolumn{2}{|c|}{$\frac{\text { Total }}{\text { Average Median }}$}} & \multicolumn{22}{|c|}{ Activities } \\
\hline & & & & & & i & ii & iii & iv & $\mathbf{v}$ & vi & vii & viii & ix & $\mathrm{x}$ & xi & xii & xiii & xiv & $\mathbf{x v}$ & xvi & xvii & xviii & xix & $x x$ & xxi & xxii \\
\hline Alashankou & PRC & 1,2 & 133 & 2 & - & & & & & & & & & & & & - & & & & & & & 2 & & & \\
\hline Khodzhadavlet & UZB & 2,3 & 39 & 100 & 100 & & & & & & & & & & & & 100 & & & & & & & - & & & \\
\hline Erenhot & PRC & 4 & 144 & 16 & - & & & & & & & & & & & - & 17 & & & & & & & - & & - & \\
\hline Saryagash & KAZ & 3,6 & 102 & 122 & 120 & & & & & & & & & & & & 122 & & & & & & & - & & & \\
\hline Zamiin-Uud & MON & 4 & 120 & 4 & - & & & & & 27 & - & & & & & 3 & 3 & & & & - & & & & - & - & \\
\hline Horgos & PRC & 1 & 167 & 14 & - & & & & & & & & & & & & 9 & & & & & & & 6 & & & \\
\hline Torghondi & AFG & 2,6 & 84 & 225 & 235 & 109 & 105 & & & & & & & & & & 11 & & & & & & & & & & \\
\hline Merke & KAZ & 1,3 & 15 & & & & & & & & & & & & & & & & & & & & & & & & \\
\hline Naushki & RUS & 4 & 48 & 24 & 24 & & & & & & & & & & 24 & & & & & & & & & & & & \\
\hline Bekabad & UZB & 2 & 5 & & & & & & & & & & & & & & & & & & & & & & & & \\
\hline Saryasia & UZB & 3 & 2 & & & & & & & & & & & & & & & & & & & & & & & & \\
\hline
\end{tabular}


Table A8 continued

\section{Rail Inbound Traffic}

\begin{tabular}{|c|c|c|c|c|c|c|c|c|c|c|c|c|c|c|c|c|c|c|c|c|c|c|c|c|c|c|c|}
\hline \multirow[b]{3}{*}{$\mathrm{BCP}$} & \multirow[b]{3}{*}{ Country } & \multirow[b]{3}{*}{ Corridor } & \multirow[b]{3}{*}{ Count } & \multicolumn{24}{|c|}{ Duration (hours) } \\
\hline & & & & \multirow{2}{*}{\multicolumn{2}{|c|}{$\frac{\text { Total }}{\text { Average Median }}$}} & \multicolumn{22}{|c|}{ Activities } \\
\hline & & & & & & i & ii & $\mathrm{iii}$ & iv & $\mathbf{v}$ & vi & vii & viii & ix & $\mathbf{x}$ & $\mathbf{x i}$ & xii & xiii & xiv & $\mathrm{xv}$ & xvi & xvii & xviii & xix & $\mathbf{x x}$ & xxi & xxii \\
\hline Dostyk & KAZ & 1,2 & 145 & 48.2 & 47.6 & & & & & 3.3 & & & & 3.0 & & & 2.4 & 0.2 & 0.2 & 0.3 & 4.8 & & 20.7 & & 14.2 & & \\
\hline Altynkol & KAZ & 1 & 167 & 44.7 & 48.9 & & & & & 1.2 & & & & & & & 0.9 & 0.2 & 0.2 & 0.3 & 11.7 & & 54.5 & & 17.9 & & \\
\hline Zamiin-Uud & MON & 4 & 253 & 24.2 & 10.3 & 6.4 & & 1.5 & & 1.7 & 3.9 & & & 2.9 & & 2.1 & 2.1 & & 1.4 & & 4.9 & & 25.0 & 3.5 & 10.8 & 3.2 & \\
\hline Serkhetyaka & TKM & 5 & 1 & 12.0 & 12.0 & & & & & & & & & & & & & & & & & & & & 12.0 & & \\
\hline Erenhot & PRC & 4 & 120 & 9.2 & 3.0 & & & & & 7.1 & 1.7 & & & & & 1.7 & 1.1 & & & & 1.2 & & 14.0 & & & & \\
\hline Termez & UZB & 3,6 & 24 & 8.9 & 9.0 & 8.3 & & & & & & & & & & & 0.6 & & & & & & & & & & \\
\hline Sukhbaatar & MON & 4 & 48 & 6.2 & 1.7 & & & & & & 4.5 & & & & & 1.3 & 0.7 & & & & 7.3 & & & & & & \\
\hline Serkhet Abad & TKM & 2,6 & 84 & 3.7 & 3.7 & & & 0.8 & & & & & & & & & 2.5 & 0.7 & & & & & & & & & \\
\hline Farap & TKM & 2,3 & 39 & 2.7 & 2.7 & & & & & & & & & & & & 2.7 & & & & & & & & & & \\
\hline Keles & UZB & 3,6 & 103 & 2.4 & 2.5 & & & & & & & & & & & & 1.9 & 0.4 & 0.4 & 0.4 & & & & & 1.3 & & \\
\hline Chaldovar & KGZ & 1,3 & 15 & 1.2 & 1.0 & & & & & & & & & & & & 0.3 & 0.3 & 0.3 & & & & & & 1.4 & & \\
\hline Naushki & RUS & 4 & 12 & 0.6 & 0.7 & & & & & & & & & & 0.6 & & & & & & & & & & & & \\
\hline $\begin{array}{l}\text { Pakhtaabad } \\
\text { (Dusti) }\end{array}$ & TAJ & 3 & 2 & & & & & & & & & & & & & & & & & & & & & & & & \\
\hline
\end{tabular}

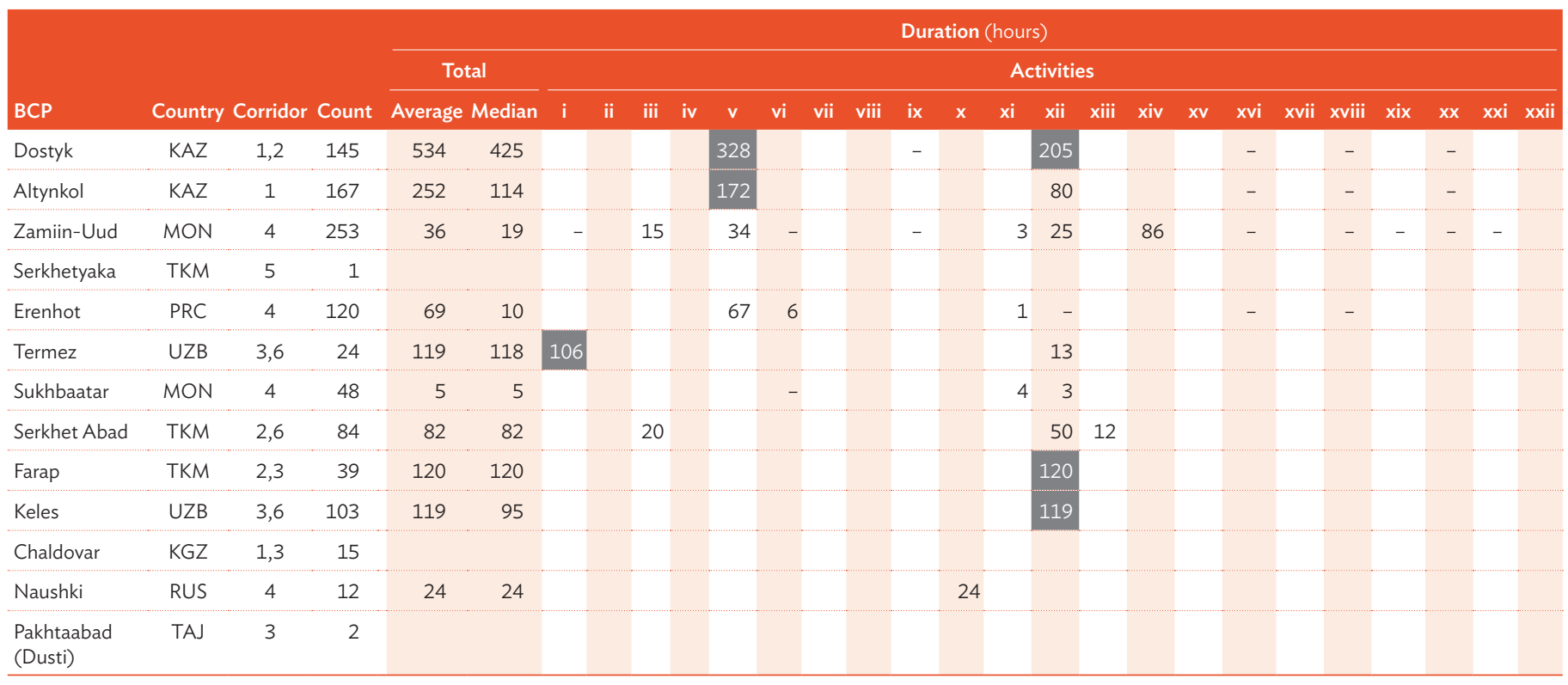

More than one hour

More than $\$ 100$

i. Load cargoes, ii. Unload cargoes, iii. Fix cargo shift, iv. Remove excess cargo, v. Transload at gauge change point, vi. Pickup and delivery, vii. Replace or repair inoperable wagon, viii. Emergency repair, ix. Train classification, x. Document errors, xi. Reissue transit documents, xii. Customs inspection, xiii. Technical inspection, xiv. Commercial inspection, xv. Sanitary and phytosanitary control, xvi. Materials transfer, xvii. Faulty handling equipment, xviii. No wagons available, xix. Restriction on entry, xx. Marshaling, xxi. Waiting for priority trains to pass, xxii. For other reasons.

- = no data, $\mathrm{AFG}=$ Afghanistan, $\mathrm{BCP}=$ border-crossing point, $\mathrm{KAZ}=$ Kazakhstan, $\mathrm{KGZ}=$ Kyrgyz Republic, MON = Mongolia, PRC $=$ People's Republic of China, RUS $=$ Russian Federation, TAJ = Tajikistan, $T K M=$ Turkmenistan, UZB = Uzbekistan.

Source: Asian Development Bank. 


\section{CAREC Corridor Performance Measurement and Monitoring Annual Report 2019}

Using data from real-time road and rail cargo shipments, the Corridor Performance Measurement and Monitoring (CPMM) mechanism assesses the efficiency of the six Central Asia Regional Economic Cooperation (CAREC) transport corridors that link CAREC member countries. It considers travel time and costs and the ease of crossing borders. Analysis of 2019 CPMM data shows steady average improvement in speed without delay, largely attributed to infrastructure investment. Delays at the border decreased but remain a major hindrance to efficient trade. This report informs policy makers about transport and trade blockages, and aims to help guide infrastructure investment and trade facilitation reform and modernization.

\section{About the Central Asia Regional Economic Cooperation Program}

The Central Asia Regional Economic Cooperation (CAREC) Program is a partnership of 11 member countries and development partners working together to promote development through cooperation, leading to accelerated economic growth and poverty reduction. It is guided by the overarching vision of "Good Neighbors, Good Partners, and Good Prospects." The CAREC countries are Afghanistan, Azerbaijan, the People's Republic of China, Georgia, Kazakhstan, the Kyrgyz Republic, Mongolia, Pakistan, Tajikistan, Turkmenistan, and Uzbekistan.

\section{About the Asian Development Bank}

ADB is committed to achieving a prosperous, inclusive, resilient, and sustainable Asia and the Pacific, while sustaining its efforts to eradicate extreme poverty. Established in 1966, it is owned by 68 members -49 from the region. Its main instruments for helping its developing member countries are policy dialogue, loans, equity investments, guarantees, grants, and technical assistance.

ADB

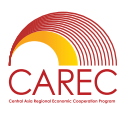

